UNIVERSIDADE ESTADUAL PAULISTA

"JÚLIO DE MESQUITA FILHO"

PROGRAMA DE PÓS-GRADUAÇÃO EM PSICOLOGIA

DO DESENVOLVIMENTO E APRENDIZAGEM

Florêncio Mariano da Costa Júnior

\title{
CONCEPÇÕES DE MÉDICOS/AS E \\ ENFERMEIROS/AS SOBRE QUESTÕES DE \\ GÊNERO NA SAÚDE
}


Florêncio Mariano da Costa Júnior

\section{CONCEPÇÕES DE MÉDICOS/AS E \\ ENFERMEIROS/AS SOBRE AS QUESTÕES DE \\ GÊNERO NA SAÚDE}

Dissertação apresentada como requisito à obtenção do título de Mestre à Universidade Estadual Paulista "Júlio de Mesquita Filho" Programa de Pós-Graduação em Psicologia do Desenvolvimento e Aprendizagem, sob a orientação da $\operatorname{Dr}^{\mathrm{a}}$ Ana Cláudia Bortolozzi Maia. 
Costa-Júnior, Florêncio Mariano da.

Concepções de médicos/as e enfermeiros/as sobre questões de gênero na saúde / Florêncio Mariano da Costa Júnior, 2010.

$121 \mathrm{f}$.

Orientador: Ana Cláudia Bortolozzi Maia

Dissertação (Mestrado) - Universidade Estadual Paulista. Faculdade de Ciências, Bauru, 2010

1. Gênero. 2. Saúde. 3. Profissionais da saúde. I. Universidade Estadual Paulista. Faculdade de Arquitetura, Artes e Comunicação. II. Título. 


\title{
UNIVERSIDADE ESTADUAL PAULISTA \\ "JULIO DE MESQUITA FILHO" \\ CAMPUS DE BAURU \\ FACULDADE DE CIENCIAS DE BAURU
}

\begin{abstract}
ATA DA DEFESA PÚBLICA DA DISSERTAÇĀO DE MESTRADO DE FLORENCIO MARIANO DA COSTA JUNIOR, DISCENTE DO PROGRAMA DE PÓS-GRADUAÇÃO EM PSICOLOGIA DO DESENVOLVIMENTO E APRENDIZAGEM, DO(A) FACULDADE DE CIENCIAS DE BAURU.
\end{abstract}

Aos 26 dias do mês de março do ano de 2010, às 14:30 horas, no(a) Sala 03 da Pós-Graduaçăo, reuniu-se a Comissão Examinadora da Defesa Pública, composta pelos seguintes membros: Profa. Dra. ANA CLAUDIA BORTOLOZZI MAIA do(a) Departamento de Psicologia / Faculdade de Ciências de Bauru, Prof. Dr. PAULO RENNES MARÇAL RIBEIRO do(a) Departamento de Psicologia Da Educação / Faculdade de Ciências e Letras de Araraquara, Profa. Dra. ALESSANDRA DE ANDRADE LOPES do(a) Departamento de Psicologia / Faculdade de Ciências de Bauru, sob a presidẽncia do primeiro, a fim de proceder a argüiçăo pública da DISSERTAÇĀO DE MESTRADO de FLORENCIO MARIANO DA COSTA JUNIOR, intitulado "Concepçōes de Médicos/as e Enfermeiros/as sobre questōes de Gênero na Saúde". Após a exposiçăo, o discente foi argüido oralmente pelos membros da Comissão Examinadora, tendo recebido o conceito final: A havendo, foi lavrada a presente ata, que, após lida e aprovada, foi assinada pelos membros da Comissâ̄o Examinadora.

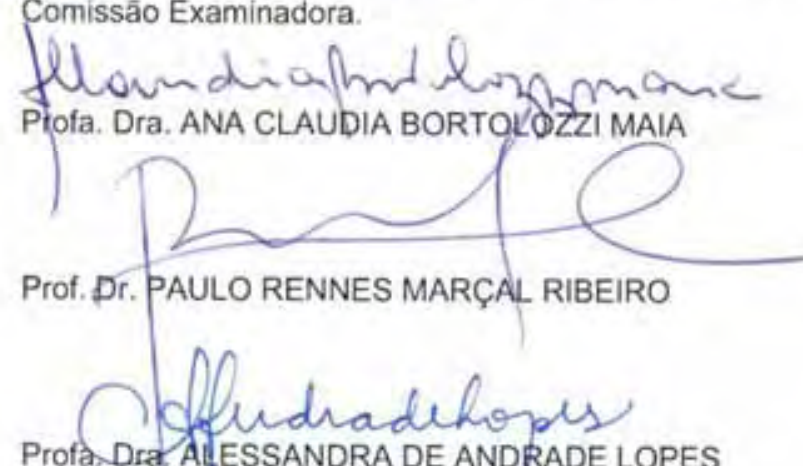




\section{AGRADECIMENTOS}

Aos meus pais, Vera e Florêncio, aos meus avós, tios/as e às minhas irmãs Janaína e Maria Carolina pelo apoio, pelos exemplos e incentivos que me guiaram intelectualmente. Em especial a Maria Carolina, que com sua dissertação "Professoras de papel" fez despertar em mim o interesse em pesquisar o gênero na saúde;

À professora Ana Cláudia Bortolozzi Maia, minha orientadora que muito além de me orientar, sem tolher minhas aspirações como pesquisador, forneceu os conhecimentos e os espaços necessários para discussão e elaboração desta pesquisa;

À professora Alessandra de Andrade Lopes por pacientemente me ensinar a ser um jovem pesquisador e por estar sempre presente em todos os momentos da minha formação acadêmica;

Ao Vitor, pelo incentivo e companhia ao longo destes anos;

Aos professores Dr. Paulo Rennes Marçal Ribeiro, Dr $^{\mathrm{a}}$. Maria Filomena Teixeira e a $\mathrm{Dr}^{\mathrm{a}}$ Alessandra de Andrade Lopes que com as contribuições no exame de Qualificação ajudaram a construir e aperfeiçoar esta Dissertação;

Aos integrantes do Grupo de Estudos e Pesquisa em Sexualidade Educação e Cultura (GEPESEC) pelo importante espaço de formação e, em especial, à Mariana Farias, companheira de trabalho, que compartilhou comigo a coordenação das reuniões de estudo desse grupo. Aos professores e colegas do programa de Pós-graduação em Psicologia do Desenvolvimento e da Aprendizagem da Unesp-Bauru que participaram e contribuíram em minha formação;

À Coordenação de aperfeiçoamento de Pessoal de Nível Superior - CAPES pela Bolsa concedida no período de março de 2009 a março de 2010;

Finalmente, aos profissionais da saúde que gentilmente se disponibilizaram a compartilhar suas concepções participando das entrevistas. 
COSTA-JUNIOR, F. M. Concepções de médicos/as e enfermeiros/as sobre questões de gênero na saúde. 2010. 122f. Dissertação (Mestre em Psicologia do Desenvolvimento e Aprendizagem) - UNESP, Faculdade de Ciências, Bauru, 2010.

\section{RESUMO}

O processo histórico e social construiu modelos de masculinidade e feminilidade que culminam em padrões e normas a serem seguidas pelos indivíduos em suas interações sociais. Nas últimas décadas estudos fundamentados nas discussões originadas no movimento feminista têm investigado a forma como as instituições sociais, incluindo aí a medicina e as demais ciências da saúde, estabeleceram ao longo da história padrões de masculinidade e feminilidade, nutrindo o discurso sexista presente no senso comum e nas ciências. Papéis sociais são atribuídos aos gêneros especificando limites rígidos de comportamento e de controle social. A noção da predisposição feminina a distúrbios físicos e emocionais gerou especulações dentro de vertentes acadêmicas culminando na criação de especialidades médicas que prevenissem o adoecimento feminino; o masculino permeado por noções de resistência e força se tornou sinônimo de corpo saudável, ratificando a dominação masculina e o papel político e econômico dos homens. Estudos indicam que as relações de gênero influenciam negativamente sobre os cuidados com a saúde. Como objetivo de estudo esta pesquisa buscou investigar, por meio de entrevistas semi-estruturadas e análise de conteúdo, as concepções sobre gênero e suas relações no cuidado com a saúde nos relatos de 11 profissionais da sáude. Os resultados obtidos indicam que para os entrevistados as características tidas como de gênero são determinadas por fatores biológicos e sociais e irão influenciar na forma como homens e mulheres lidam com a sua saúde e doença. De acordo com os resultados há uma diferença significativa na interação com homens e mulheres sendo que as interações profissionais com o público feminino são entendidas como mais satisfatórias. Para os participantes a formação profissional não abordou as questões de gênero e as estratégias para lidar com as demandas masculinas e femininas foram aprendidas na prática profissional reforçando estereótipos e preconceitos. Os dados originados pelo presente estudo subsidiam a discussão sobre a prática profissional e as questões de gênero na área da saúde. A partir deste estudo novas pesquisas poderão investigar a relação das mulheres e homens com os cuidados em saúde bem como suas respectivas identidades. Pesquisas que busquem desenvolver estratégias formativas na área da saúde ao que se refere às questões de gênero podem prosseguir com os resultados deste estudo e propiciar a elaboração de políticas públicas abrangentes e uma formação em saúde que considere o gênero como fator social, político e histórico, inerente aos cuidados em saúde.

Palavras-chave: Gênero; Saúde; Concepções de profissionais da saúde; Masculino; Feminino. 
COSTA-JUNIOR, F. M. Doctor's and Nurse's conceptions on Gender issues in health. 2010. 122f. Master thesis presented to Postgraduate Program in Psychology of Development and Learning - UNESP, Faculdade de Ciências, Bauru, 2010.

\begin{abstract}
The historical and social process has built models of masculinity and femininity that culminate in standards and norms to be followed by individuals in their social interactions. In recent decades studies based on the discussions that originated in the feminist movement have been investigating how social institutions, including medicine and other health sciences, have established standards of masculinity and femininity throughout the history, nurturing this sexist discourse on common sense and sciences. Social roles are assigned to the genera specifying rigid boundaries of behavior and social control. The notion of the female predisposition to physical and emotional disorders has prompted speculation within academic strands culminating in the creation of specialized medical illness that would prevent the female, the male permeated by notions of endurance and strength has become synonymous of a healthy body, confirming the male domination and the economic and political role of men. Studies indicate that gender relations influence negatively on health care. This research concerned to study and investigate through semi-structured interviews and content analysis, conceptions of gender and its relationship to health care in reports of 11 health professionals. The results obtained indicate that for the interviewed subjects that the regarded characteristics of gender are determined by biological and social factors and will influence the way men and women deal with their health and disease. According to the results there is a significant difference in interaction with men and women being the professional interactions with the female audience perceived as more satisfactory. For the participants the professional background did not address gender issues and strategies to cope with the demands male and female were learned in professional practice reinforcing stereotypes and prejudices. The data generated by this study subsidize the discussion on professional practice and gender issues in the field of health. From this study, further research could investigate the relationship between women and men with health care as well as their respective identities. Research that seek to develop training strategies for health in relation to gender issues can proceed with the results of this study and encourage the development of public policies and a comprehensive health education that considers gender as a factor of social, political and historical inherent in health care.
\end{abstract}

Keywords: Gender, Health, Conceptions of health professionals; Male, Female. 


\section{SUMÁRIO}

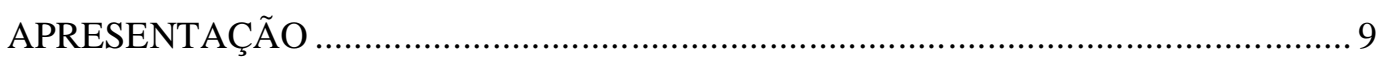

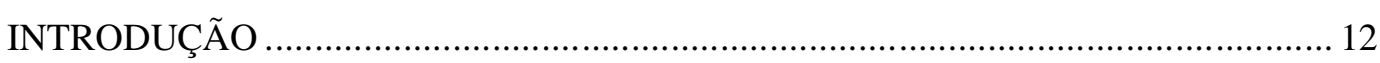

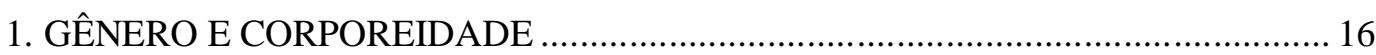

1.1 Definições introdutórias sobre gênero e relações de gênero.................................... 16

1.2. A masculinidade e a feminilidade no contexto atual.......................................... 25

1.3. Corporeidade e gênero: controle e normatização do corpo.................................... 28

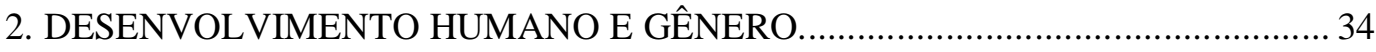

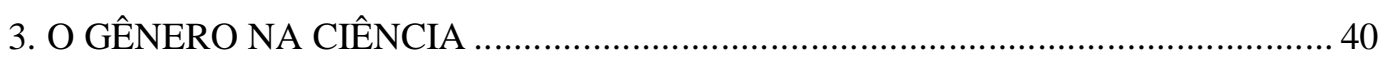

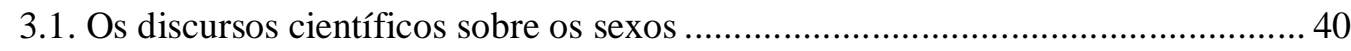

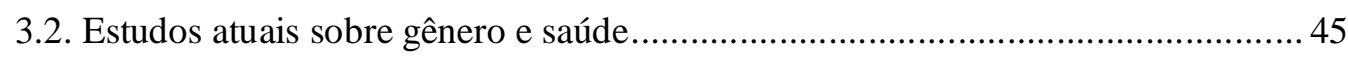

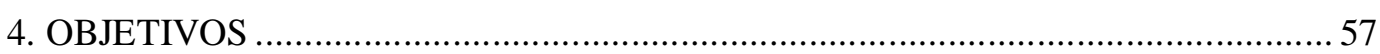

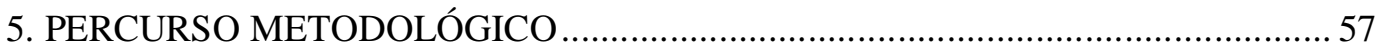

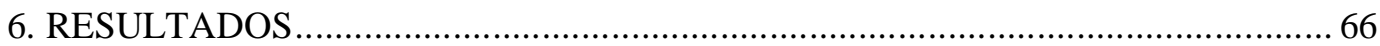

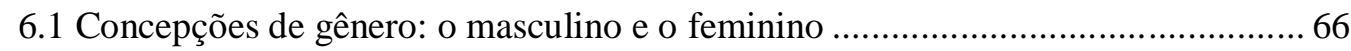

6.1.1 Gênero como agrupamento ou diferenciação sexual...................................... 66

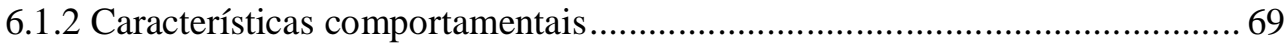

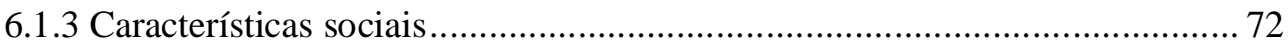

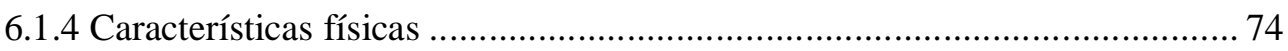

6.2 Gênero e Comportamentos de cuidados com a saúde/doença ............................... 75

6.2.1 Comportamentos de cuidados com a saúde e doença em função do gênero .. 75

6.2.2 Compreensão de como e por que mulheres e homens cuidam da saúde e lidam com a doença e com o tratamento ........................................................................ 79

6.3 Atuação cotidiana no atendimento a homens e a mulheres............................... 86

6.4 Formação acadêmica relacionada às questões de gênero.................................. 90

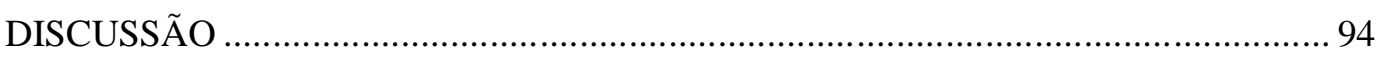

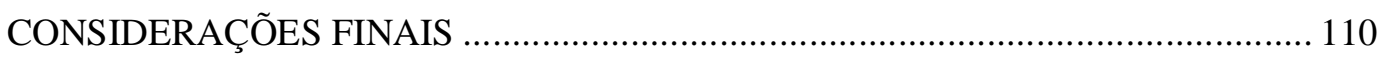

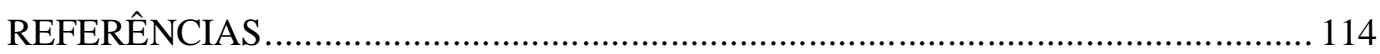

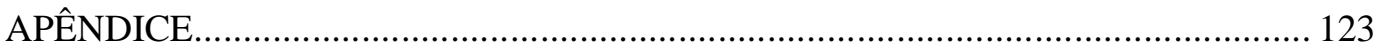

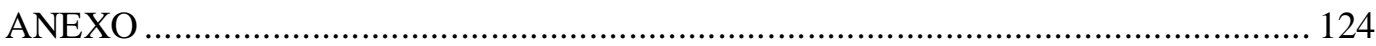




\section{APRESENTAÇÃO}

Existem momentos na vida onde a questão de saber se se pode pensar diferentemente do que se pensa, e perceber diferentemente do que se vê, é indispensável para continuar a olhar ou refletir. (...) mas o que é filosofar hoje em dia - quero dizer, a atividade filosófica - senão o trabalho crítico do pensamento sobre o pensamento? Se não consistir em tentar saber de que maneira e até onde seria possível pensar diferentemente em vez de legitimar o que já se sabe? (FOUCAULT, 1984, p. 13)

Acredito que neste momento inicial seja relevante descrever os elementos constitutivos da minha motivação para pesquisar e vivenciar ao longo de dois anos as questões de gênero nas concepções de profissionais da saúde. Então, convido o leitor ou a leitora a conhecer parte da minha trajetória pessoal que contribui decisivamente para a elaboração desta pesquisa.

De certa forma a minha vontade de saber sobre o gênero e sua influência na saúde de homens e mulheres se iniciou ainda na graduação. No ano de 2004 , atuei em um projeto de extensão, coordenado pela professora Alessandra de Andrade Lopes, que visava promover atendimento humanizado em uma unidade de orientação e prevenção do câncer. Nesta experiência na área da saúde pude notar a diferença em relação ao número de homens e mulheres que procuravam os serviços preventivos em oncologia. A cada 20 pacientes atendidos, em média 18 eram mulheres para dois homens e esses acima de 50 anos de idade.

Ainda nos serviços de saúde me deparei com as habilidades profissionais necessárias para lidar com as demandas diversificadas dos pacientes. Atender um homem ou uma mulher hospitalizada me pareceu ser uma atividade diferente. De modo geral, a interação entre mim e os homens e as mulheres atendidos era qualitativamente distinta, as mulheres se sentiam à vontade durante as intervenções e falavam mais sobre si. Isto era angustiante, pois percebia minha incapacidade para lidar em certos momentos com os 
pacientes do sexo masculino. Por que havia uma dificuldade em concluir satisfatoriamente uma intervenção com os homens? Esta questão me desconcertava! Essa dúvida aliada ao sentimento de incapacidade técnica para entrevistar e abordar os homens e assim atingir os objetivos das intervenções impulsionou-me a um intenso investimento acadêmico e pessoal.

Somada a experiência do estágio, tive também na minha graduação participação no Grupo GEPESEC, em que comecei o aprofundamento teórico sobre sexualidade e gênero para a realização de um estudo sobre a representação do corpo e da sexualidade masculina na revista "Mens Health" e outro, que resultou em um artigo no periódico "Psicologia: Teoria e Pesquisa" sobre a relação entre gênero e saúde a partir do relato de homens hospitalizados, intitulado "Concepções de homens hospitalizados sobre a relação entre gênero e saúde".

Nas situações profissionais ouvia sobre o que os homens e mulheres hospitalizados tinham para falar sobre sua história e sobre seus cuidados com a saúde. Constantemente ouvia nos corredores do hospital frases como: "Já está tão mocinha! Para que tanto choro, seja mais boazinha”, "Já está quase um homem, meninos não choram”. Recordava também das repetidas histórias dos homens da minha família que adoeciam gravemente pelo fato de não se engajarem na prevenção e nos tratamentos e, em contrapartida, via certo exagero na busca das mulheres pelas terapêuticas, pelos remédios ou cirurgias.

Assim, fui me reconhecendo nas pesquisas sobre a saúde do homem e saúde da mulher na perspectiva das relações de gênero e elaborei para o Curso de Mestrado o projeto de pesquisa "Concepções de médicos/as e enfermeiros/as sobre as questões de gênero na saúde”, que foi realizado sob a orientação da professora Ana Cláudia Bortolozzi Maia. Este projeto, então, foi resultado de experiências acadêmicas, profissionais e também pessoais. 
Percebi na revisão bibliográfica que os termos "mulher", "saúde da mulher" e "feminino" eram constantemente abordados enquanto que raramente se falava sobre o "homem" ou ao "masculino". Além disso, o homem, a masculinidade e o gênero em termos relacionais "homem-mulher" ou "masculino-feminino" não estavam em pauta naqueles contextos da saúde e muito menos no dia-a-dia das pessoas que atuavam na área da saúde. As justificativas das pessoas, incluindo as minhas, para o fato de ser diferente a forma com que homens e mulheres lidam com a saúde me pareceriam reducionistas; nós profissionais da saúde, não sabíamos ao certo os motivos que diferenciavam os comportamentos de cuidados com o corpo entre homens e mulheres.

Tive acesso aos estudos que versavam sobre a medicalização excessiva das mulheres e sobre as políticas que almejavam inserir os homens na pauta da saúde coletiva. Já havia realizado uma pesquisa anterior ouvindo o ponto de vista dos indivíduos que buscam por cuidados e não dos profissionais da saúde que os atendiam, assim, me pareceu significativo propor um estudo que abordasse as concepções dos agentes que promovem os cuidados - os profissionais da saúde. 


\section{INTRODUÇÃO}

A compreensão sobre "o que é ser homem" ou "ser mulher" define-se em termos culturais a partir de modelos de masculinidade e feminilidade predominantes que culminam em padrões e normas a serem seguidas pelos indivíduos em suas interações sociais quando se trata de relações de gênero ${ }^{1}$ (CONNELL, 1995; NOLASCO, 1993; UNBEHANUM, 2003).

A noção de gênero e as configurações sobre o masculino e o feminino não determinam somente as atitudes e os comportamentos interpessoais a serem adotados e esperados socialmente, mas também influenciam na forma como os indivíduos devem perceber e lidar com seus corpos (CONNELL, 1995; COURTNAY, 2000; DOYAL, 2001; GOMES, 2003; KORIN, 2001; UNBEHANUM, 2003).

Ao mesmo tempo em que a ciência delimitava o papel da mulher, contribuía também para a manutenção de um ideal de masculinidade. No campo da saúde, os discursos científicos atribuíam ao feminino, uma predisposição a distúrbios orgânicos e psicológicos e, ao mesmo tempo, ao masculino, a noção de resistência e de responsabilidade sobre a manutenção social e econômica (COSTA-JUNIOR; MAIA, 2009; GOMES, 2003; KORIN, 2001; ROHDEN, 2003).

Abordar as questões de gênero nos leva a necessidade de discorrer sobre o movimento feminista, pois é por e pelas pautas do movimento das mulheres que o termo foi cunhado para se referir as relações de poder entre homens, mulheres e instituições.

A historiadora Maria Joana Pedro (2005) indica que o movimento social do feminismo teve dois momentos distintos denominados como "feminismo de primeira onda" e "feminismo de segunda onda". O movimento feminista de primeira onda teria se desenvolvido no final do século XIX e se baseava nas reivindicações sociais e

\footnotetext{
${ }^{1} \mathrm{O}$ termo relações de gênero se refere ao modo como as culturas organizam a hierarquia entre as pessoas em função do sexo mediada pelas relações de poder existentes nos diversificados contextos sociais (SCOTT, 1995).
} 
econômicas, tais como o direito de trabalho remunerado, a propriedade e a herança. Já o movimento chamado de "segunda onda", emergente após a Segunda Guerra Mundial priorizou os debates sobre o direito ao corpo, ao prazer e o manifesto contra o patriarcado e a subordinação das mulheres. Foi justamente no movimento feminista de segunda onda que a categoria gênero foi criada e a luta política feminista passou então a incluir o masculino como uma construção histórico-social indissociável do feminino (PEDRO, 2005).

As discussões sobre gênero iniciadas pelas feministas americanas na década de setenta referiam-se à organização social da relação entre os sexos e naquele momento histórico sublinhavam o aspecto relacional das definições normativas de feminilidade (ACKER, 1995; SCOTT, 1995). No interior do movimento feminista americano os avanços nos debates investiam na perspectiva relacional entre masculinidade $\mathrm{e}$ feminilidade e segundo Scott (1995):

as que estavam mais preocupadas com o fato de que a produção dos estudos femininos centrava-se sobre as mulheres de forma muito estreita e isolada, utilizaram o termo "gênero" para introduzir uma noção relacional no nosso vocabulário analítico. Segundo esta opinião, as mulheres e os homens eram definidos em termos recíprocos e nenhuma compreensão de qualquer um poderia existir através de estudos inteiramente separado (SCOTT, 1995 p. 01).

O início do movimento feminista ${ }^{2}$ no Brasil ocorreu simultaneamente a ditadura militar o que restringiu a repercussão dos debates a contextos privados e particulares da militância. O movimento esteve marcado pela luta por eqüidade de direitos das mulheres e pela busca em novas possibilidades de constituição de identidades (SARTI, 2004). A partir dos anos oitenta, com o fim da ditadura militar e a anistia daquelas mulheres que haviam sido exiladas, há o fortalecimento de um cenário histórico importante em que se desnaturalizava a concepção dominante de mulher e de feminilidade e denunciava as

\footnotetext{
${ }^{2}$ Para maiores informações sobre o percurso histórico do movimento feminista no Brasil sugerimos a leitura do texto de Cynthia A. Sarti (2004) intitulado: "O feminismo brasileiro desde os anos 1970: revisitando uma trajetória".
} 
diferenças e dificuldades enfrentadas pelas mulheres, no que diz respeito à atenção integral a sua saúde (SARTI, 2004; TELES, 1999). A reflexão feminista gerou, no âmbito acadêmico e nas políticas públicas, críticas ao essencialismo das biociências e visou retirar a saúde da mulher ${ }^{3}$ de uma esfera unicamente reprodutiva, redefinindo assim o seu papel na sociedade. Esse movimento pontuou as reais necessidades femininas, expondo demandas até então veladas pela ciência e, entre elas, podemos citar os métodos contraceptivos e o aborto (AQUINO, 2005; OLIVEIRA, 2000; ROHDEN, 2003).

A produção científica sobre a relação de gênero na área da saúde ainda é escassa, principalmente, na investigação desse tema entre os profissionais da saúde que têm contato direto com mulheres e homens em instituições de atenção primária, secundária e terciária. Nesse sentido, estudar o que relatam tais profissionais, sobre como homens e mulheres se engajam nos cuidados com a saúde, bem como o atendimento que lhes são prestados, nos parece uma questão fundamental que poderia produzir conhecimentos mais abrangentes sobre o tema e contribuir para a instrumentalização de programas de prevenção e da formação profissional daqueles que devem garantir a atenção integral à saúde, respondendo às demandas específicas do gênero feminino e masculino.

A revisão teórica que fundamenta a análise na qual esse estudo está proposto será apresentada em três seções. Na primeira seção "Gênero, sexualidade e corporeidade" serão abordadas algumas das temáticas introdutórias que julgamos necessárias para a compreensão das discussões acadêmicas sobre gênero. Inicialmente versaremos sobre o conceito de gênero a partir de diferentes teorias e sua utilização na atualidade. Tal explanação almeja dar aporte para o subcapítulo que é denominado de "A masculinidade e

\footnotetext{
${ }^{3} \mathrm{O}$ termo saúde da mulher cunhado pelas ciências médicas no século XIX, constituiu a base para a ciência da mulher e logo para a normatização do corpo feminino por meio de intervenções médicas que visam apenas a manutenção da condição reprodutiva e o controle sobre a sexualidade da mulher. O movimento feminista resgatou este termo com o propósito de lhe atribuir novos significados e desvelar as reais necessidades das mulheres para além da perspectiva reprodutiva e materna (AQUINO, 2005; ROHDEN, 2001; VIEIRA, 2002).
} 
a feminilidade no contexto atual" que relacionará o tema às condições de saúde de homens e mulheres. Ao final do primeiro capítulo apresentaremos o gênero como estratégia de normatização do corpo no subcapítulo "corporeidade e gênero: controle e normatização do corpo".

A segunda seção “Desenvolvimento humano e socialização de gênero" abordará o gênero como um fator importante no desenvolvimento humano, tratando de questões como a socialização sexista e a influência da família no processo de educação e de formação do gênero.

A terceira seção "O Gênero na ciência" irá tratar das concepções sobre gênero e sobre as diferenças sexuais presentes no discurso científico, especialmente, na história dos séculos XIX e XX. Além disso, nesse capítulo também apresentaremos alguns estudos recentes que versam sobre gênero relacionado à saúde de homens e de mulheres.

Por fim, o método utilizado para coletar e analisar os dados, os resultados obtidos e analisados serão apresentados e discutidos. 


\title{
1. GÊNERO E CORPOREIDADE
}

\begin{abstract}
"Meu corpo é resultado de um enorme feitiço. E os feiticeiros foram muitos: pais, mães, professores, padres, pastores, gurus, líderes políticos, livros, Tv. Meu corpo é um corpo enfeitiçado: porque o meu corpo aprendeu as palavras que lhe foram ditas, ele se esqueceu de outras que, agora permanecem mal...ditas" (Rubem Alves - "O Sapo")
\end{abstract}

\subsection{Definições introdutórias sobre gênero e relações de gênero}

De acordo com as autoras Scott (1995), Acker (1995) e Pedro (2005) nos anos 80 os estudos sobre temas relacionados à história das mulheres substituíram em seus títulos os termos "sexo" e "mulheres" pelo termo "gênero". A partir disto o conceito de gênero dissocia-se da política do feminismo e integra-se à terminologia científica das ciências sociais, adquirindo um status de categoria de análise. O seguinte trecho de Pedro (2005) explicita os motivos pelos quais o termo gênero se insere no debate feminista:

\begin{abstract}
Em português, como na maioria das línguas, todos os seres animados e inanimados têm gênero. Entretanto, somente alguns seres vivos têm sexo. Nem todas as espécies se reproduzem de forma sexuada; mesmo assim, as palavras que as designam, na nossa língua, lhes atribuem um gênero. E era justamente pelo fato de que as palavras na maioria das línguas têm gênero mas não têm sexo, que os movimentos feministas e de mulheres, nos anos oitenta, passaram a usar esta palavra "gênero" no lugar de "sexo". Buscavam, desta forma, reforçar a idéia de que as mulheres não eram dependentes do "sexo" como questão biológica, mas sim eram definidas pelo "gênero" e, portanto, ligadas à cultura (PEDRO, 2005, p. 78)
\end{abstract}

Joan Scott (1995) identificou três abordagens utilizadas na análise do gênero: 1) as abordagens que buscavam explicar as origens do patriarcado; 2) as abordagens que, vinculadas a teoria marxista, lutavam pelas críticas feministas e 3) as abordagens divididas entre o pós-estruturalismo francês e as teorias anglo-americanas, que inspiradas nas escolas psicanalíticas, buscavam explicar a produção e reprodução da identidade de gênero dos sujeitos (SCOTT, 1995).

Utilizaremos no presente estudo o termo gênero como uma organização social da diferença sexual: uma categoria histórica, de caráter constitutivo das subjetividades 
humanas e que irá fundamentar (e será fundamentado por) outras duas concepções: "homem" e "mulher" que por sua vez sintetizam significados e atributos construídos ao longo da história e do desenvolvimento da sociedade civilizada (ACKER, 1995; SCOTT, 1995).

Na língua portuguesa o termo gênero se estabelece principalmente como classes ou estilos nos quais objetos e seres são agrupados de acordo com suas características e atributos em comum. A seguir estão destacados os possíveis significados do termo presente Novo Dicionário Aurélio (edição eletrônica versão 5.0, 2004):

\begin{abstract}
"gênero: [Do lat. genus, eris, 'classe', 'espécie', poss. pelo pl. lat. genera, ou pelo lat. *generum, com mud. de declinação.] Substantivo masculino. 1.Lóg. Classe cuja extensão se divide em outras classes, as quais, em relação à primeira, são chamadas espécies. 2.Lóg. Um dos predicáveis (q. v.): característica(s) que uma coisa tem em comum com outra, e que lhe(s) determina(m) a essência, quando acrescida da diferença (8). [Cf., nesta acepç., classe (22).] 3.P. ext. Qualquer agrupamento de indivíduos, objetos, fatos, idéias, que tenham caracteres comuns; espécie, classe, casta, variedade, ordem, qualidade, tipo: Freqüentava todo gênero de gente; Que gênero de conversa é esta?; Nesta rua há todo gênero de casas. 4.Maneira, modo, estilo: Não concordo com esse gênero de vida. 5.Nas obras de um artista, de uma escola, cada uma das categorias que, por tradição, se definem e classificam segundo o estilo, a natureza ou a técnica: os gêneros literários, musicais, pictóricos. 6.Classe ou natureza do assunto abordado por um artista: gênero dramático; gênero romântico. 7.Antrop. A forma culturalmente elaborada que a diferença sexual toma em cada sociedade, e que se manifesta nos papéis e status atribuídos a cada sexo e constitutivos da identidade sexual dos indivíduos [grifos do autor]. (Dicionário Aurélio edição eletrônica versão 5.0, 2004).
\end{abstract}

No trecho acima, o item em destaque (item "7"), aproxima o significado da palavra "gênero" ao qual iremos discutir neste estudo e engloba-se a esse termo o agrupamento de características anatômicas, fisiológicas e comportamentais comuns ao homem ou a mulher.

No dia-a-dia o termo "gênero" é comumente utilizado para se referir ao sexo biológico: gênero masculino (homem) e gênero feminino (mulher). Tais noções são compostas por idéias, percepções e atributos, criados nas relações sociais, para se referir a sujeitos que nasceram com um determinado sexo biológico e que no propósito da 
reprodução da espécie, possuem funções diferenciadas (LAMAS, 2000; MORO, 2001). Para Martins (2004) a nova ciência biológica do sexo iniciada no século XVIII só via

um avolumar-se de diferenças, fosse entre os minerais, fosse entre as plantas e os animais, fosse entre os seres humanos. Entre eles, a nova ciência biológica do sexo mostrava como homens e mulheres eram diferentes e como as diferenças físicas e até mesmo químicas eram determinantes na vida social de ambos (MARTINS, 2004, p.32)

Quanto a esse ponto de vista, cabe destacar que para alguns autores a função diferenciada sobre a reprodução da espécie é o que inicialmente serviu como base para a constituição das atuais diferenças sociais existentes entre homens e mulheres em suas inter-relações (LAMAS, 2007; MENEZES; HEILBORN, 2007).

Em todas as sociedades, nós, seres humanos, somos confrontados com um fato idêntico: a diferença sexual. O corpo é a primeira evidencia incontestável da diferença humana. No entanto, cada cultura constrói uma forma particular para simbolizar e conceber a diferença, produzindo múltiplas versões sobre a dicotomia homem/mulher (LAMAS, 2007). E são essas maneiras de compreender e simbolizar a diferença sexual que fundamentam a concepção de gênero e suas variadas características dentro de uma sociedade. A formulação simbólica das diferenças sexuais ganha forma nos conjuntos de práticas subjetivas, representações sociais que influenciam e condicionam a conduta objetiva e subjetiva dos indivíduos em função do seu sexo (LAMAS, 2007; MENEZES; HEILBORN, 2007).

As classificações culturais fundamentam os dispositivos ${ }^{4}$, as obrigações sociais de cada sexo, e também uma série de proibições que asseguram a manutenção da dicotomia entre masculino e feminino (LAMAS, 2000; 2007). Mais do que a distinção sexual, o gênero marca a percepção e a relação humana nas esferas sociais, políticas e religiosas

\footnotetext{
4 Dispositivo segundo Foucault é "um conjunto decididamente heterogêneo que engloba discursos, instituições, organizações arquitetônicas, decisões regulamentares, leis, medidas administrativas, enunciados científicos, proposições filosóficas, morais, filantrópicas. Em suma, o dito e o não dito são os elementos do dispositivo. O dispositivo é a rede que se pode estabelecer entre esses elementos (FOUCAULT, 2005, p. 244).
} 
bem como enviesa a produção de conhecimento de modo a legitimar os mecanismos de exclusão e dominação (BUTLER, 2008; BOURDIEU, 2003; LAMAS, 2000; 2007).

Como vimos, a sociedade ordena e delimita espaços diferenciados, tarefas complementares e atitudes distintas em função do gênero, o que por sua vez dificulta conceber as mulheres e os homens como iguais perante a sociedade e diferentes como seres humanos (LAMAS, 2007). Em um artigo denominado "Gênero é cultura" Lamas (2007) diz:

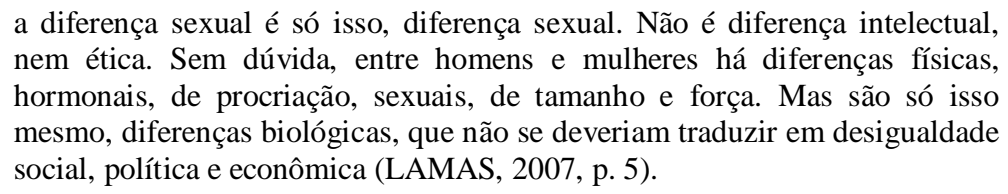

Lamas (2007) descreve o gênero como o conjunto de prescrições, crenças e atribuições que são construídas socialmente tendo por base a diferença sexual. Nesse viés o gênero é uma construção histórica que considera o que se é próprio de cada sexo e na base da concepção de gênero se têm as matérias do sexo e da procriação moldadas por conjuntos de regras, expectativas e crenças sociais. A construção cultural e social que define padrões de gênero funciona como uma forma de se interpretar o mundo e a partir desse modelo pode haver várias implicações sociais, de acordo com o corpo masculino ou feminino, como por exemplo, restrições de decisões, oportunidades e possibilidades (BUTLER, 2008; LAMAS, 2007).

Segundo Lamas (2000) e Scott (1995) o conceito gênero permite a compreensão de que não é a anatomia que posiciona homens e mulheres em hierarquias distintas, mas sim a forma como as sociedades concebem e simbolizam o caráter anatômico e as diferenças dos corpos masculinos e femininos. Esta compreensão é reelaborada por Laqueur (2001) ao conceber o gênero não apenas como a forma como são percebidas as diferenças entre os sexos, mas sim como um fator antecessor a própria definição do que é o sexo biológico. Em síntese Laqueur (2001) advoga que gênero, ou seja, aquilo que 
define a posição de homens e a mulheres na sociedade, irá fundar o que se entende como sexo biológico e seus atributos. Portanto, em análise, sexo e gênero não estão separáveis. Nas palavras do autor

quase tudo que se queira dizer sobre sexo - de qualquer forma que o sexo seja compreendido - já contém em si uma reivindicação sobre o gênero. O sexo, tanto no mundo do sexo único como no de dois sexos, é situacional: é explicável apenas dentro do contexto de luta sobre gênero e poder. (LAQUEUR, 2001, p. 23).

Durante muitos séculos a humanidade acreditou que as diferenças entre homens e mulheres estavam determinadas apenas pela diferença anatômica e sexual. No entanto, as pesquisas de caráter histórico, antropológico e psicológico das últimas décadas demonstram a existência de diversas interpretações sobre a diferença sexual entre homens e mulheres, bem como as formas que esse fenômeno se produz culturalmente e varia de uma sociedade para outra (MENEZES; HEILBORN, 2007). Nas sociedades indígenas ou civilizadas, podemos encontrar representações discrepantes sobre aquilo que define o homem e a mulher, no entanto, o corpo sempre será o local onde a representação se fará visível, ou seja, o corpo será o instrumento público que as normas de masculinidade e feminilidade serão expressas e reproduzidas (MEAD, 1979; MENEZES; HEILBORN, 2007; SARTI, 2001). Butler (2008) e Bourdieu (2003) situam o gênero como um processo que articula sexo, desejo e prática sexual, no qual o corpo é moldado pela cultura através do discurso.

Os debates teóricos de Judith Butler amalgamados no referencial psicanalítico pósestruturalista tal como a Teoria Queer ${ }^{5}$, fundamentada nos estudos culturais norteamericanos e no pós-estruturalismo francês, concebem o gênero sob uma ótica

\footnotetext{
${ }^{5}$ A Teoria Queer surgiu nos Estados Unidos no final década de 1980 como uma proposta de oposição crítica aos estudos sociológicos sobre as minorias sexuais e gênero. Tal teoria tem como objeto de análise a dinâmica da sexualidade e do desejo na organização das relações sociais (MISKOLCI, 2009).
} 
particularmente distinta baseada na analítica da normalização ${ }^{6}$. A metodologia dos estudos Queer e seus apontamentos políticos problematizaram as concepções clássicas de sujeito e identidade, sendo o sujeito sempre provisório, circunstancial e cindido (LOURO, 2001; MISKOLCI, 2009).

A Teoria Queer destaca a centralidade dos mecanismos sociais, mantenedores dos binarismos tais como homem/mulher, hetero/homossexual e ressalta a necessidade de uma política do conhecimento e da diferença. Dessa forma os teóricos Queer focam suas atenções nas práticas sociais e nos conhecimentos que organizam a sociedade a partir do binarismo de modo a desconstruir ou desestabilizar a lógica dos discursos binários que centram os sujeitos em condições opositivas na construção de sua identidade (MISKOLCI, 2009). Segundo essa perspectiva os discursos que reivindicam direitos e condições igualitárias aos sujeitos acabam por reproduzir a norma uma vez que tais discursos não abordam as condições binárias como interdependentes e co-existentes (LOURO, 2001; 2003).

Guacira Louro (2001) se refere à desconstrução como proposta metodológica da Teoria Queer dizendo:

\begin{abstract}
A operação de desconstrução, proposta por Jacques Derrida, parecerá, para muitos teóricos e teóricas, o procedimento metodológico mais produtivo. Conforme Derrida, a lógica ocidental opera, tradicionalmente, através de binarismos: este é um pensamento que elege e fixa como fundante ou como central uma idéia, uma entidade ou um sujeito, determinando, a partir desse lugar, a posição do outro, o seu oposto subordinado (...) essa lógica poderia ser abalada através de um processo desconstrutivo que estrategicamente revertesse, desestabilizasse e desordenasse esses pares. Desconstruir um discurso implicaria em minar, escavar, perturbar e subverter os termos que afirma e sobre os quais o próprio discurso se afirma (LOURO, 2001, p. 548).
\end{abstract}

Nos debates científicos sobre as "questões gênero" estão condensados um arcabouço teórico diferenciado e interessado em investigar as categorias de agrupamento, dicotomias e as representações de "homem" e "mulher", "masculino" e "feminino",

\footnotetext{
${ }^{6}$ Ver artigo de Miskolci (2009) intitulado "A Teoria Queer e a sociologia: o desafio de uma analítica da normalização".
} 
"masculinidade" e "feminilidade". Os resultados dos estudos sobre gênero nos permitem conhecer que as diferenças atribuídas aos sujeitos masculinos e femininos perpassam a diferença sexual e reprodutiva, atinge esferas subjetivas e no âmbito social instituiu-se como diferença e discriminação (LAMAS, 2007).

Durante seu desenvolvimento homens e mulheres são educados em função das naturezas distintas: vivem e são conduzidos por motivações e interesses distintos como fazendo parte de papéis pré-definidos atribuídos aos sexos. A sociedade modela as "diferenças" a partir de crenças que são fundamentadas em estereótipos de gênero sociais e culturais (GRACIANO, 1978; LAMAS, 2007). No contexto das relações de poder, esses papéis irão especificar o acesso e também as possíveis opções por parte daqueles sujeitos que se enquadram no construto tido como "masculino - homem" ou "feminino - mulher". Cria-se assim, situações de estratificação, violência e repressão de acordo com o gênero enquanto sexo biológico e papel social (BORDO, 1997).

Quem primeiro discutiu e alarmou sobre as discriminações que envolviam as opressões do sexo feminino foram as feministas que reivindicaram e lutaram por direitos iguais diante de uma sociedade pautada na estrutura social falocêntrica e no controle patriarcal. Historicamente, o movimento feminista não lutou apenas pela eqüidade de direitos entre mulheres e homens, mas desvelou fatos históricos e discursos que subjugavam as minorias. No bojo dos debates do movimento feminista havia denúncias relativas às posições das mulheres na sociedade, bem como das barreiras encontradas por algumas mulheres determinadas a romper os limites definidos de poder e direito que lhes eram conferidas. Os debates feministas e a pressão crescente das mulheres na busca de direitos igualitários e sexuais adentraram os contextos acadêmicos a partir dos anos setenta repercutindo em avanços significativos no cenário científico e cultural (ACKER, 1995; RAGO, 1998; TELLES, 1999). 
Os desdobramentos das proposições sociais e científicas do feminismo revisaram a construção histórica das relações humanas e sociais e as construções teóricas desse movimento atingiram diversas disciplinas e áreas do conhecimento. Segundo Rago (1998):

\begin{abstract}
a emergência de novos temas, de novos objetos e questões, especialmente ao longo da década de setenta deu maior visibilidade às mulheres enquanto agentes históricos, inicialmente a partir do padrão masculino da História Social, extremamente preocupada com as questões da resistência social e das formas de dominação política. Este quadro ampliou-se, posteriormente, com a explosão dos temas femininos da Nouvelle Histoire, como bruxaria, prostituição, loucura, aborto, parto, maternidade, saúde, sexualidade, a história das emoções e dos sentimentos, entre outros (RAGO, 1998, p. 13).
\end{abstract}

$\mathrm{Na}$ ótica inicial do movimento feminista, a situação desfavorável das mulheres consistia em um poder controlador por parte dos homens, sendo esses dominadores das instituições sociais, do saber produzido pela ciência e reguladores daquilo que é ou que não é possível para as mulheres (BOURDIEU, 2003; BUTLER, 2008; LAMAS, 2007; RAGO, 1998).

Lamas (2000) se refere a uma tensão existente na discussão em torno das relações de gênero. A autora aponta que mesmo não considerando as mulheres idênticas aos homens, o pensamento feminista reformulou duas perguntas que ainda causam dissenso: 1) se há uma igualdade essencial entre os sexos, qual é esta igualdade? 2) se há uma diferença essencial em que consiste tal diferença?"(LAMAS, 2007, p.13). De tais questionamentos emergiriam no movimento feminista o dilema entre lutar pela igualdade com os homens ou reivindicar a diferença como mulheres. Não encontrando uma solução para tais questionamentos, Lamas (2000; 2007), Scott (1995) defendem que homens e mulheres são iguais enquanto seres humanos e diferentes quanto aos sexos e que, portanto, não se pode optar pela igualdade ou pela diferença.

O movimento feminista e a sua compreensão sobre gênero teve e tem uma importância fundamental para se pensar a relação entre homens e mulheres e também a 
construção histórica do corpo feminino ${ }^{7}$. No entanto, durante muitas décadas a grande parte da produção dos estudos denominados 'estudos de gênero' ainda analisava o tema em uma via de mão única, isto é, alguns desses estudos reduziam a discussão somente ao campo do feminino (GOMES, 2003). Essa parcialidade pode ser um produto da dicotomia masculino e feminino que historicamente contextualizou a relação entre as instituições, ciência, subjetividade e cultura.

Outros estudos, porém, passaram a abordar a questão como uma via de mão dupla e não somente sob a ótica da dominação masculina. Desse modo, as discussões atuais sobre questões de gênero compreendem que tanto homens como mulheres são "dominados e dominadores" e co-responsáveis pela manutenção das classificações que normatizam o masculino e o feminino (CONNEL, 1995; GOMES, 2003).

Para Connell (1995) e outros autores, gênero se define conceitualmente pela forma na qual as

capacidades reprodutivas e as diferenças sexuais dos corpos humanos são trazidas para a prática social e tornadas parte do processo histórico, assim as masculinidades são apreendidas e utilizadas sem deixar de ser também um fenômeno social, assim o gênero é mais do que interações entre homens e mulheres. É nas relações de gênero que este conceito se interliga aos aspectos econômicos, familiares e sexuais (CONNELL, 1995, p. 187).

Ou seja, as diferenças marcadas pelo corpo biológico têm representação social atribuída pela cultura a partir de um conjunto de idéias, concepções ou valores sexuais que se agrupa naquilo que entendemos por gênero. Esse "padrão" de gênero é colocado em nossa cultura como algo dicotômico - masculino ou feminino e isso acaba por segregar e manter as divisões sobre aquilo que se poderia sentir, pensar e fazer, quando se é homem ou mulher.

\footnotetext{
${ }^{7}$ A investigação histórica relativa ao corpo feminino revelou construções estigmatizadoras e misóginas do poder médico. A concepção médica dominante até os anos 60 preconizava que a constituição física da mulher inviabilizava sua entrada no mundo nos negócios e da política (RAGO, 1998).
} 


\subsection{A masculinidade a a feminilidade no contexto atual}

Connell (1995) define a masculinidade como uma configuração de comportamentos cotidianos em torno da posição dos homens na estrutura das relações de gênero. Tais comportamentos não são necessariamente racionais e possuem um significado cultural que os determinam. São práticas produzidas e moldadas nas interações dos sujeitos em seu ambiente e contexto cultural.

Gomes (2003) e Nolasco (1993) observam que, o masculino tornou-se um gênero permeado de inconsistências e conflitos na sociedade patriarcal. Para os autores, não foram as conquistas do feminismo que determinaram as dificuldades do masculino, apenas às evidenciaram. Diferentemente dos homens, que ainda não questionaram determinadas regras, as conquistas do movimento feminista implicaram mudanças significativas em relação à igualdade de direitos entre homens e mulheres (GOMES, 2003; TELES, 1999).

Em nosso cotidiano é possível observar atributos que prescrevem um modelo masculino predominante em nossa cultura. Esse modelo de masculinidade não é biologicamente determinado como muitas teorias sociobiológicas querem fazer crer e acabam povoando o discurso e as práticas sociais. O padrão masculino é determinado pelo contexto histórico e social, é aprendido e mantido pelas relações do indivíduo em seu ambiente (UNBEHANUM, 2003; MAIA, 2005; WHITAKER, 1988; 1995).

Diferentes masculinidades e feminilidades são produzidas no mesmo contexto social e são essas normas que sustentam os modelos hegemônicos responsáveis pela naturalização de condutas estereotipadas.

A masculinidade hegemônica apresenta como modelo ideal, homens ativos, fortes e capazes de trabalho físico árduo. Características que saiam dessa prescrição são consideradas tipicamente femininas e, portanto, punidas. Homens que apresentam tais 
características são vistos como fracos, afeminados ou homossexuais (CONNEL 1995; GOMES, 2003; KORIN, 2001; MAIA; MAIA, 2009; NOLASCO, 1993).

Da mesma forma, as diferentes feminilidades também são produzidas pelo contexto social. A feminilidade hegemônica apresenta como ideal a mulher fraca, passiva e dependente. Para Bordo (1997), as normas relativas ao feminino podem ser evidenciadas na relação da feminilidade com o corpo da mulher. Bordo (1997) diz:

\begin{abstract}
nós, mulheres, estamos gastando muito mais tempo com o tratamento e a disciplina de nossos corpos como demonstram inúmeros estudos. (...) através da busca de um ideal de feminilidade evanescente, homogeneizante, sempre em mutação - uma busca sem fim e sem descanso, que exige das mulheres que sigam constantemente mudanças insignificantes e muitas vezes extravagantes da moda. (...) os corpos femininos tornam-se o que Foucault chama de "corpos dóceis": aqueles cujas forças e energias estão habituadas ao controle externo, à sujeição, à transformação e ao "aperfeiçoamento. (...) Por meio de disciplinas rigorosas e reguladoras sobre a dieta, a maquiagem, e o vestuário somos convertidas em pessoas menos orientadas para o social e mais centradas na automodificação. (BORDO, 1997 p. 20)
\end{abstract}

Como vimos, a interpretação dada à diferença sexual e anatômica aparece como fundamento de subordinação e opressão de homens e mulheres. Uma importante influência científica que contribuiu para a reprodução de gênero foi a ciência médica ${ }^{8}$, evidentemente calcada nas diferenças anatômicas e fisiológicas da espécie humana. No entanto, a partir das diferenças orgânicas e os estudos médicos e científicos sobre essa diferença, as questões de gênero reproduziram as representações sociais e culturais. Dizendo de outro modo, muitas concepções sociais e culturais atribuídas ao feminino e ao masculino, foram justificadas e reforçadas pela ciência sexista (BORDO, 1997; MARTINS, 2004; ROHDEN, 2001).

A estrutura dessa diferenciação faz-se a partir do anatômico e do reprodutivo, ou seja, das experiências essencialmente diferentes entre homens e mulheres: a sexualidade e a procriação (MARTIN, 2006). Ainda que essas diferenças sejam características centrais no ser humano, que têm raiz biológica e orgânica, elas não se constituem integralmente na

\footnotetext{
${ }^{8}$ O percurso histórico das ciências médicas, quanto ao gênero e as diferenças sexuais, será abordado no capítulo 3 deste estudo.
} 
cidadania do sujeito, ou seja, não são em si mesmas as condições que determinam o lugar de homens e mulheres na sociedade e, portanto, não deveriam fundamentar o sexismo (LAMAS, 2007).

As concepções de gênero se fundamentam na lógica da complementaridade entre homens e mulheres que extrapola o âmbito reprodutivo e isso atingiu os cenários sociais e os diferentes aspectos da vida dos seres humanos. O gênero como uma manifestação cultural das diferenças sexuais opera como marcador de tarefas e instrumento para estratificar os indivíduos diante de suas características sexuais, anatômicas e psicológicas.

A falsa noção de complementaridade se torna um mecanismo que atua não somente para certificar a subordinação feminina, mas também para respaldar as discriminações diante daqueles que não correspondem às condutas hegemônicas de masculinidade ou feminilidade (LAMAS, 2007), pois, uma vez que esses não serviriam como papéis complementares por estarem aquém das expectativas sociais, seriam pessoas avaliadas como negativas e de menor prestígio social.

A posição das mulheres ou dos homens, suas atividades, suas limitações e possibilidades variam de acordo com a interpretação cultural sobre a diferença sexual e a crença na complementaridade existencial serve para limitar o desenvolvimento de certas potencialidades e a variabilidade nos comportamentos. O gênero torna-se uma pauta de expectativas e crenças que marcam a organização da vida coletiva e produz desigualdades na forma como as pessoas respondem as ações de homens e mulheres.

Assim, as informações que circunscrevem a concepção de gênero são antecedentes às informações que relacionam e diferenciam os sexos e suas especificidades biológicas: ser homem ou mulher biologicamente (LAMAS, 2007; LAQUEUR, 2001). A sociedade produz idéias de como devem ser os homens e as mulheres e suas respectivas características masculinas ou femininas nas esferas da vida pública ou privada. E como 
defendem Lamas (2007) e Connell (1995), o que se valoriza (ou discrimina) como feminino e masculino varia conforme a cultura - latino-americana, islâmica, escandinava ou oriental.

Os papéis de gênero por se formarem no conjunto de normas e prescrições, estabelecidas culturalmente fundamentam a dicotomia entre masculino e feminino que se traduzem socialmente como estereótipos de gênero, condicionando e restringindo as possibilidades de acesso, bem como os comportamentos de acordo com o gênero dos indivíduos (GRACIANO, 1978; HIDALGO; LAMAS, 2000; LOURO, 2003; PALÁCIOS, 2004; REIS, 2008). Os papéis se tornam estereótipos sexuais quando determinam de modo rígido e inflexível, um conjunto de comportamentos, sentimentos e modos de ser em função do gênero, isto é, de determinado lado da dicotomia - homem versus mulher.

\subsection{Corporeidade e gênero: controle e normatização do corpo.}

O corpo humano historicamente foi e ainda é objeto de interesse de várias ciências e que por variados motivos se configurou como cenário no qual atuam os instrumentos de normatização e adequação dos indivíduos segundo as normas e valores vigentes nos diferentes períodos da história da humanidade. Ao classificar as diferenças corporais existentes entre os sexos, as ciências formataram as concepções naturalizadas dos papéis sociais atribuídos a homens e mulheres e, consequentemente, sobre a forma como os indivíduos lidam com seus corpos.

O corpo é o instrumento e objeto no qual os caracteres genéticos e também as normas sociais operam. Além disso, é o cenário onde se atuam as intervenções em saúde. Podendo esse corpo ser saudável ou doente, as ciências da saúde focam nele sua maior atenção, ou seja, é no corpo que se manifestam as doenças e é nele que se deve promover a saúde. Desde a fecundação o corpo inicia seu processo de transformação e durante as 
etapas de desenvolvimento psicológico, todos os humanos passam por um processo de socialização pautado em normas de conduta e valores (GIFFIN, 1991; MARTIN, 2006). Ao longo da vida, todos nós, somos formados e formadores dessas normas, somos conduzidos por significados sobre o corpo (ROHDEN, 2001; 2003).

O debate acadêmico acerca do corpo humano passa a ser analisado como uma construção histórica e subjetiva. Seguindo essa compreensão, o corpo é uma condição humana contingente à construção histórica e cultural que de modo incisivo fundamenta a constituição da subjetividade sendo, essa última composta dentre outros fatores, pela identidade de gênero e pelas relações de gênero. Tal como nos apontam Rohden (2001; 2003). Mosse (1998) e Martins (2004) as intervenções e estudos sobre o corpo masculino e feminino são distintas e ao longo da história os desdobramentos dessa diferenciação fortaleceram o estabelecimento de padrões normativos socialmente considerados "adequados", referentes a um ou outro sexo biológico que respaldaram a discriminação dos "desviantes".

A palavra "Corpo" (Corpo humano) é usualmente utilizada em nossa língua para definir a entidade orgânica da qual os seres humanos são constituídos, ou seja, sua estrutura física, seu aparato biológico ou seu mecanismo anatomofisiológico. Tal definição não abarca todas as utilizações do termo, tampouco descreve o seu papel diante do funcionamento coletivo e individual em nossa atual sociedade. Durante séculos as ciências, sejam elas as ciências naturais ${ }^{9}$ ou ciências médicas, analisaram o corpo humano somente em seu aspecto físico e funcional. A partir dos anos 30 do século passado, novos atributos são adicionados à noção de "Corpo" e é nesse cenário social que o corpo e a corporeidade ultrapassam os debates restritos ao viés biológico. (GIFFIN, 1991; MARTINS, 2001).

\footnotetext{
${ }^{9}$ São agrupadas como ciências naturais aquelas que têm como objetivo de estudo a natureza em torno do homem, sendo este incluído apenas na condição de animal natural: a física, a química, a astronomia, a geologia, a biologia (NOVO DICIONÁRIO AURÉLIO, 2004)
} 
Para Marcel Mauss (1974) o corpo é o primeiro instrumento do ser humano, e como tal é um objeto técnico e meio técnico ao mesmo tempo. Seguindo esse ponto de vista pode-se concluir que é com o corpo e através dele que os seres humanos manifestam suas condições culturais, sociais e psicológicas, ou seja, é no corpo que se operacionalizam condutas sociais e é através dele que normas e valores são transmitidos numa dada comunidade e cultura.

As formas, atos e padrões estéticos de utilização do corpo configuram aquilo que Marcel Mauss (1974) conceituou de "Técnicas corporais", sendo tal conceito amplamente utilizado nas ciências humanas. Desse modo, as formas de utilização do corpo por meio de técnicas corporais, são provenientes das experiências vividas pelos indivíduos, é a partir da relação entre o homem e a sociedade que são configurados o seu modo de ser, sentir ou de agir (SARTI, 2001).

Segundo Sarti (2001) o processo de socialização $^{10}$ implica dois momentos indissociáveis: o contato do indivíduo com a sociedade, ou seja, com a realidade objetiva; e a interiorização dessa como realidade subjetiva. Seguindo esse raciocínio, os indivíduos só irão construir suas experiências e concepções, mediante as referências coletivas iniciadas logo ao nascer e renovadas ao longo de seu desenvolvimento.

Autores como Sarti (2001) e Mauss (1974), defendem que o corpo, para além do seu caráter anatomofisiológico, é produto de processos culturais inerentes a uma dada sociedade. Portanto o corpo, seus significados, seu uso e o cuidado que lhe é prestado de modo individual ou coletivo é fruto de uma aprendizagem social que resulta na construção de uma condição psicológica em cada indivíduo. Os autores compartilham a idéia de corpo como linguagem adquirida culturalmente, sendo os costumes um tipo de ordem desta linguagem da qual os sujeitos não tem total clareza (não são conscientes), "tal como

\footnotetext{
${ }^{10} \mathrm{O}$ processo de socialização ao longo do desenvolvimento humano será abordado de forma mais detalhada no capítulo "Gênero e desenvolvimento humano".
} 
a gramática da língua não é plenamente conhecida pelos falantes, a ordem da linguagem simbólica do corpo não é amplamente conhecida pelos seus agentes" (SARTI, 2001, p. 6).

O corpo não é apenas um instrumento técnico resultante da interação cultural; é, sobretudo, um lugar prático no qual o controle social exerce seu poder (FOUCAULT, 1981). É por meio da organização e regulamentação do tempo, do espaço e das convenções cotidianas que os corpos são disciplinados segundo a forma histórica dominante de individualidades, desejos, masculinidade ou feminilidade, e dessa forma, o controle social fundamentaria e homogenizaria o "habitus" - o "modus operandi" das condutas e práticas sociais típicas de uma classe, grupo social, gênero, etc (MAUSS, 1974; SARTI, 2001; BORDO, 1997). Mauss (1974) define "habitus" como as práticas sociais e os hábitos que "não variam simplesmente com os indivíduos e suas imitações, mas, sobretudo, com as sociedades, as educações, as conveniências e as modas, com os prestígios” (MAUSS, 1974, p.214).

Os modos de vida ou as práticas sociais são de todo modo, transmitidas pelas instituições formadoras, as quais podem ser agrupadas em dois conjuntos: as instituições que cuidam: a família, os sistemas de saúde; e as instituições que ensinam, como escolas, organizações, centros de saúde etc. Sarti (2001) discorre sobre o controle coercitivo inerente às práticas coletivas, nas quais a coerção aparece quando se tenta sair da regra, ou seja, quando os indivíduos buscam resistir ou transformar práticas consolidadas e normativas existentes dentro das instituições sociais. Então o corpo, tal como a formação de subjetividade, se constitui a partir de uma tensão constante entre sujeito com suas particularidades e o coletivo com suas regras de conduta rigidamente estabelecidas.

Sarti (2001) se referindo aos estudos desenvolvidos junto à comunidade indígena, aponta que nessas comunidades havia um ideal no qual a sociedade submetia o corpo a periódicos processos de fabricação. Tais processos são distintos daquilo que nas 
sociedades civilizadas chamamos de intervenção médica, pois essa prática, como advoga Foucault (1981), realizam-se como práticas de poder que ferem a autonomia do sujeito em relação a seu próprio corpo e isso não ocorre no contexto indígena. Nas sociedades tribais o apoderamento do corpo é um processo pedagógico no qual é inserido código ao corpo. A sociedade imprime sua marca no corpo e com isso os indivíduos passam a ser reconhecidos pela fidelidade à lei, a vontade de ser e a de pertencer a um grupo. Nesse sentido os tribais conhecem claramente os motivos pelos quais e para os quais o corpo é fabricado e as etapas que pressupõem os momentos de intervenção social (SARTI, 2001). Os significados sociais marcam claramente as formas como a experiência corpórea será vivida nos momentos de rituais de fabricação do corpo.

Nos ambientes modernos, o corpo também sofre intervenções, sejam ela físicas ou sociais. Nesses momentos as clivagens do gênero, instituem modos distintos de lidar com a experiência corpórea, assim suportar a dor em silêncio, pode ser sinal de virilidade em algumas culturas que em contrapartida, permitem e valorizam a expressão explícita do sofrimento nas mulheres (SARTI, 2001).

O papel antes desempenhado pelo líder religioso da comunidade indígena, agora é assumido por profissionais da saúde que irão interferir decisivamente na significação do corpo do paciente (FOUCAULT, 1981; SARTI, 2001). Desse modo a forma como o profissional reage diante dos comportamentos do doente influencia na própria reação do paciente diante do tratamento - ambos qualificando a experiência com o corpo e seus aspectos subjetivos (SARTI, 2001). Segundo Montanger (2006), nesse cenário operam as representações, e tais representações são manifestações de um Habitus que, objetivas por si mesmas, exercem sua coerção sobre os indivíduos.

A aprendizagem decorrente dos processos de instrução sobre o corpo produz relações distintas entre a função, a necessidade e o manejo do corpo de acordo com o sexo 
biológico. Nesse sentido, homens e mulheres aprendem a perceber e lidar de maneira diferente com seu corpo, pois estes são socialmente representados na cultura segundo a norma: prescritiva de um masculino saudável, ativo e resistente em contraste a um feminino frágil, instável e sensível a doenças.

As diferenças sociais que em nossa cultura caracterizam os sexos irão delimitar determinados percursos para o desenvolvimento social e psicológico de homens e mulheres. Os escritos de Graciano (1978), Afonso (1995), Reis (2008) e Maia e Maia (2009) têm mostrado como a educação familiar e institucional são importantes para "ensinar" modelos comportamentais de masculinidade e feminilidade através da socialização. Quando internalizadas ou aprendidas pelos sujeitos, as normas do que é masculino e feminino ou do que é ser homem ou ser mulher são reproduzidas no dia-a-dia e com isto mantém as desigualdades de socialização e educação. O Capítulo seguinte abordará a influência das questões de gênero sob o desenvolvimento humano. 


\section{DESENVOLVIMENTO HUMANO E GÊNERO}

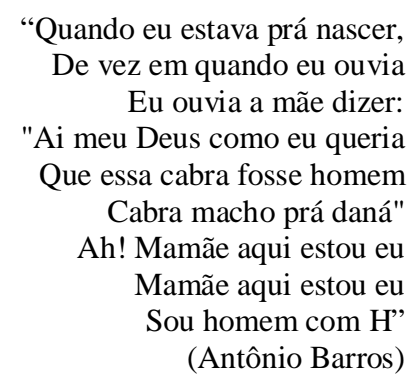

Os seres humanos, segundo Lamas (2007) nascem dentro de relações culturais em que já se inscrevem valores e crenças sobre o que é ser homem e o que é ser mulher. Nossa percepção acerca do mundo desde o início está condicionada pela forma já estabelecida na cultura em que habitamos, dessa maneira, no caso de gênero, a constituição individual e psicológica é desde sempre influenciada pelo discurso social dominante no que se refere ao "ser homem" ou "ser mulher" (GRACIANO, 1978; LAMAS, 2007).

Nos seres humanos a identidade de gênero se estabelece junto a aquisição da linguagem e é anterior ao conhecimento da diferença anatômica entre os sexos. Nessa etapa do desenvolvimento, a criança estrutura suas experiências com o gênero ao qual pertence e identifica suas manifestações (GRACIANO, 1978; HIDALGO; PALÁCIOS, 2004). A experiência da criança com seu sexo biológico e com as primeiras abstrações e prescrições sociais de padrões hegemônicos culminam na formação de gênero (LAMAS, 2000; MORO, 2001).

As relações de gênero são estabelecidas e aprendidas de modo gradual por meio de processos de socialização que se iniciam logo após o nascimento e, nesse sentido, a família tem grande responsabilidade na educação sexista (GRACIANO, 1978; MAIA; MAIA, 2009; PARKER, 2000; ROCHA, 2000; WHITAKER, 1995). Estudos mostram que os membros da família reproduzem uma educação sexual e moral diferenciada em relação ao gênero de seus filhos/as, evidenciando vantagens e desvantagens na infância 
justificadas pelo gênero que pertencem (BELOTTI, 1979; MORENO, 1999; MAIA;

MAIA, 2009; NAVARRO, 2005; REIS, 2008; WHITAKER, 1995). Maia e Maia (2009)

comentam:

\begin{abstract}
Ao nascimento, os cuidadores vão contribuindo para a educação sexista por meio de várias atitudes, em geral de modo não proposital ou consciente: posturas como segurar o bebê, falar com ele, escolher a vestimenta (roupas de cores diferentes), dedicar-se aos cuidados com a higiene, dedicar-se à amamentação são aspectos que, de acordo com pesquisas, são "diferenciados" em relação ao gênero. Mães de bebês fazem de tudo para mostrar ao mundo se seu bebê é menino ou menina (e ficam ofendidas se os outros não discriminam o sexo do bebê). (...) No desenvolvimento de meninos e meninas várias diferenças de tratamento contribuem para manter estereótipos: permite-se às meninas chorar, serem passivas, recatadas, limpinhas e exige-se delas o treino de habilidades domésticas (desde cedo elas põe a mesa e lavam a louça enquanto o irmão vê TV com o pai), habilidades manuais (fazer tricô, costurar, fazer colar, etc.) e artísticas (pintar, por exemplo). Ao mesmo tempo, aos meninos é proibido chorar (mesmo quando se trata de uma criança de dois anos que perdeu seu brinquedo predileto), fazer balé (é melhor fazer judô, karatê ou algum esporte), aprender música (clássica, embora a guitarra seja estimulada) e vários outros exemplos do nosso cotidiano, tão evidentes e, ao mesmo tempo, tão sutis. Em geral, principalmente no caso de meninos, não se permite a flexibilização de padrões de gênero, sob o risco de serem considerados "menos homens" ou homossexuais, o que sabemos ser um equívoco (MAIA; MAIA, 2009, p.49).
\end{abstract}

A educação sexista nas instituições familiares e escolares, comum na infância e na adolescência, procura adequar o sujeito para que ele corresponda o mais coerentemente possível aos modelos de masculino e feminino que são considerados "normais" na sociedade e isso, segundo Maia e Maia (2009), representa um "custo emocional para todos - tanto para as mulheres quanto para o homem, em reproduzir o modelo de gênero existente, pois há sempre punições para aqueles que não se adaptam" (MAIA; MAIA, 2009, p.50).

Percebemos as representações do "feminino" e do "masculino" através da linguagem e das relações culturais com objetos e imagens. Desde muito pequenas as crianças já se identificam como pertencentes a um ou a outro gênero. Por volta do segundo ou terceiro ano de vida, meninos e meninas já sabem referir-se a si mesmos em feminino ou masculino mesmo que não tenham a clara noção sobre as diferenças sexuais, ou seja, 
não sabem claramente das diferenças anatômicas, mas sabem diferenciar roupas ou costumes que são próprios de meninos ou meninas (HIDALGO; PALÁCIOS, 2004). E isso tem relação direta com a educação que recebem (OLIVA, 2004a, 2004b).

Nas últimas décadas a relação entre gênero e desenvolvimento humano foi objeto de estudo de pesquisadores de diferentes áreas das ciências: educadores, psicólogos etc. Graciano (1978) e Hidalgo e Palácios (2004) defendem que as expectativas parentais são fundamentais para a configuração do ambiente familiar no qual o recém nascido será recebido.

A relação entre contexto ambiental, composto por práticas parentais, cultura, normas e valores é notavelmente distinta em relação ao sexo biológico. Graciano, (1978), Whitaker (1995) e Belotti (1975) comentam que os processos sociais responsáveis pela construção dos papéis sexuais são iniciados a partir da gestação quando já existem expectativas sobre o sexo do bebê.

O tratamento diferenciado que meninos e meninas recebem ao longo de sua socialização, além estimular ou inibir o acesso a determinados contextos, produzem o desenvolvimento de determinadas habilidades e características pessoais diferenciadas e isto é interpretado em nossa sociedade como natural, determinado pelo sexo biológico e não pela cultura (GRACIANO, 1978; HIDALGO; PALACIOS, 2004; WHITAKER, 1995).

Os estudos de Graciano (1978), Silva, Guarido e Graciano (1976), Karraker; Vogel e Lake (1995) demonstram que pais e mães possuem expectativas e percepções diferentes quando de tratam de bebês masculinos ou femininos. Nas conclusões desses autores os pais consideram as meninas mais prestativas, delicadas e interessadas à vida doméstica e à vida privada. Os meninos por sua vez são vistos como menos prestativos, mais agressivos e competitivos, voltados para as atividades públicas (SILVA, GUARIDO; GRACIANO, 
1976). Traços mais delicados são atribuídos aos bebês femininos mesmo quando esses não apresentam diferenças estéticas comportamentais perceptíveis (GRACIANO, 1978; KARRAKER; VOGEL; LAKE, 1995) e as mães tendem a demonstrar melhores expectativas profissionais para os filhos, sendo que profissões de maior reconhecimento social e financeiro são também atribuídas a crianças do sexo masculino (KARRAKER; VOGEL; LAKE, 1995; REIS, 2008).

A socialização diferencial repercute ao longo de todo o ciclo vital e há efeitos significativos sobre a auto-estima de homens e mulheres,

\begin{abstract}
enquanto nos meninos a auto-estima seguirá uma clara linha ascendente, entre as meninas os níveis irão se manter baixos e podem, inclusive, descender (...) essas diferenças podem ser explicadas claramente pelos processos de socialização, que, a partir da puberdade, tendem a ampliar o leque de possibilidades e de experiências que são oferecidas ao menino (OLIVA, 2004a, p. 339).
\end{abstract}

O ambiente de educação formal não foge às normatizações do gênero e segundo dados analisados por Afonso (1995), as educadoras tendem a considerar meninas mais carinhosas e mais fáceis de lidar e isto atua na formação do autoconceito das crianças. A crença sobre as meninas dóceis, atenciosas e carinhosas e seus respectivos antônimos sobre os meninos irá repercutir na formação da identidade desses indivíduos (AFONSO, 1995, GRACIANO, 1978, HIDALGO; PALÁCIOS, 2004).

De acordo com Moro (2001) os professores tendem a considerar de maneira mais positiva as produções acadêmicas de meninos em detrimento das meninas, e isso claramente resulta em um maior engajamento dos meninos nas atividades de pesquisa e na produção científica. Esses educadores legitimam a desigualdade de oportunidades, pois, provavelmente compartilham da concepção na qual as distintas constituições cerebrais resultariam em diferentes capacidades em meninos e meninas, e assim seus desempenhos seriam recebidos e avaliados de forma diferente (MORO, 2001; NAVARRO, 2005). 
As expectativas e crenças em relação ao gênero, existentes no ambiente social produzem como produto exatamente aquilo que se espera e se acredita ser condizente a um determinado gênero. Uma vez que meninos e meninas são estimulados de forma diferencial, acabam desenvolvendo habilidades e características de personalidade distintas e aquilo que era uma expectativa e crença passa a ser um traço de personalidade, um comportamento (GRACIANO, 1978; HIDALGO; PALÁCIOS, 2004). Um exemplo é o fato de a educação de homens, em geral, resultar em comportamentos de retração emocional e baixa responsividade parental, ao passo que a mulher é avaliada positivamente. Os homens que apresentam responsividade parental ou cuidados de maternagem são subjugados como emocionalmente feminilizados simplesmente por se interessarem por essas práticas e por não corresponder ao padrão masculino hegemônico e heterossexual (CONNELL, 1995; GRACIANO, 1978).

A influência social atua de maneira marcante, principalmente sobre valores e comportamentos apropriados a cada sexo que são, progressivamente, apreendidos na educação geral. Na medida em que se aprendem as atitudes adequadas, homens e mulheres passam a manifestar automaticamente comportamentos socialmente esperados, independentemente de controle ou punições externas (GRACIANO, 1978. HIDALGO; PALACIOS, 2004) porque a regra já foi internalizada (MAIA; MAIA, 2009).

Ainda que entendamos a biologia como uma variável que influencia diretamente para o produto final das características masculinas e femininas, essas características não existem independentemente da cultura em que os sujeitos se desenvolvem. A influência biológica, portanto,

se define pela atuação dos hormônios sexuais e a influência cultural pela atuação do meio social na modelagem de comportamentos. $\mathrm{O}$ estudo destes dois determinantes é na verdade bastante difícil em seres humanos, pois existe uma complexa interação de ambos a partir do momento em que a criança nasce e penetra no mundo social. Não se pode pensar em criar indivíduos totalmente isolados das influências sociais, nem tampouco em se atuar diretamente sobre os fatores hormonais. Por outro lado, generalizações de resultados obtidos em 
estudos com animais não podem ser aceitas sem cautela (GRACIANO, 1978 p. $31)$.

Os estudos antropológicos de Margareth Mead (1979) corroboram com essa hipótese da aprendizagem social dos gêneros. Nesses estudos são evidenciadas distinções significativas entre os papéis sexuais de nossa cultura e de outras culturas primitivas o que por sua vez reforça que a atribuição de comportamentos ao sexo masculino ou feminino é arbitraria, pois depende de condições culturais. Segundo a autora tais evidências

\begin{abstract}
permite-nos afirmar que muitos, senão todos, os traços de personalidade que consideramos masculino ou feminino têm uma ligação tão tênue com o sexo quanto as roupas, o jeito e a forma de penteado que a sociedade prescreve em dado momento para os sexos (...) Somos forçados a concluir que a natureza humana é inacreditavelmente maleável, respondendo de forma precisa e contrastante às condições culturais (...) Diferenças e padrões de traços de personalidade entre os sexos são deste tipo, criações culturais às quais cada geração, masculina e feminina, é treinada a se conformar (MEAD, 1979 p. 268).
\end{abstract}

Podemos dizer, então, que até o presente momento não se tem conhecimento de pesquisas, nas ciências humanas, que contraponham $\mathrm{o}$ fato de que atributos comportamentais constituintes da masculinidade e a feminilidade são predominantemente aprendidos por múltiplos processos, estratégias e práticas culturais estabelecidas pelas instâncias sociais ainda que diferenças anatômicas possam exercer certa influência nesses atributos (GRACIANO, 1978; MAGALHÃES; RIBEIRO, 2009; MAIA; MAIA, 2009; MEAD, 1979). A diferença presente na anatomia e nas funções sexuais e reprodutivas de homens e mulheres não parece ser capaz de induzir a prevalência de inteligência ou ética distinta para um determinado sexo (MAGALHÃES; RIBEIRO, 2009). São as concepções construídas sobre a biologia que fundamentam a discriminação. No capítulo seguinte veremos os discursos fundamentados nas ciências e os enredos discriminatórios contidos nas ciências da saúde ao longo da história. 


\title{
3. O GÊNERO NA CIÊNCIA
}

\begin{abstract}
A distinção principal nos poderes mentais dos dois sexos reside no fato de que o homem chega antes que a mulher em toda ação que empreenda, requeira ela um pensamento profundo ou então razão, imaginação, ou simplesmente o uso das mãos e dos sentidos (....) podemos também concluir que, se em muitas disciplinas os homens são decididamente superiores às mulheres, o poder mental médio do homem é superior àquele destas últimas (Charles Darwin, 1974, p. 649).
\end{abstract}

\subsection{Os discursos científicos sobre os sexos}

A epígrafe de abertura ilustra um dado científico, referente às diferenças entre os sexos, que fundamentou e foi fundamentado por vieses sociais que durante séculos buscavam justificativas para as dificuldades ou facilidades existentes entre os sujeitos masculinos ou femininos. Tal afirmação científica conduz à dois pontos iniciais de reflexão: 1) os pontos de vista da ciência são influenciados por concepções sociais préexistentes e 2) tais concepções sociais foram e ainda são ratificadas ou modificadas pelo discurso científico. Ao longo desta seção estão situados alguns dos movimentos da ciência que constituíram as bases para as afirmações de que o masculino e o feminino possuíam em sua condição genética os fatores que determinavam as diferenças comportamentais, e logo os diferentes desempenhos em tarefas comuns do cotidiano.

No século II d. C., Galeno desenvolveu seu modelo de identidade estrutural dos órgãos sexuais concluindo que mulheres eram essencialmente homens, mas que por não possuírem o calor vital se tornavam seres imperfeitos. Galeno claramente defendia que os corpos masculinos e femininos, como variações de um sexo único, eram expressões de uma ordem natural e hierárquica que organizava o mundo dos seres vivos (LAQUEUR, 2001; MARTINS, 2004).

O calor vital sendo o princípio fundamental para a perfeição fundamentava a metafísica de hierarquia pela qual estavam norteadas as representações do homem e da mulher (LAQUEUR, 2001). A mulher era imperfeita por ter seu sexo interno: a vagina sendo um pênis invertido, os ovários os testículos internos e o útero o saco escrotal 
projetado para dentro. Nessa mesma concepção o calor menor nas mulheres mantinha o útero na cavidade abdominal e propiciava um ambiente de temperatura moderada para a gestação (LAQUEUR, 2001). Nesse modelo científico os princípios de quente ou frio correspondiam às manifestações de uma realidade estável, na qual o elemento quente, e, portanto o masculino, era dominante e visto como ápice da cadeia dos seres vivos, estando abaixo nesta ordem hierárquica a mulher, pois era considerada mais fria e úmida (MARTIN, 2006; MARTINS, 2004; LAQUEUR, 2001).

O modelo de um sexo único baseado na perfeição metafísica e no calor vital orientou as visões sobre os gêneros até o início do movimento iluminista na Europa. A referência do corpo feminino como incompleto, formou representações conceituais e pictóricas no período anterior ao iluminismo, construindo um ambiente propício para que concepções radicais entre os sexos fossem fortificadas nos séculos seguintes e consequentemente pela ciência moderna no século XIX (MARTIN, 2006; MARTINS, 2004; LAQUEUR, 2001).

Os modelos científicos pós-iluminismo, contestavam a idéia de um sexo único e defendiam um novo modelo pautado na divergência biológica entre os sexos - o dimorfismo radical existente na composição dos seres de sexo masculino e feminino. Assim, nas palavras de Laqueur (2001):

\footnotetext{
uma anatomia e fisiologia de incomensurabilidade substituiu uma metafísica de hierarquia na representação da mulher com relação ao homem (...) Não só os sexos são diferentes, como são diferentes em todo aspecto concebível do corpo e da alma, em todo aspecto físico e moral (...) a relação da mulher com o homem é uma 'série de oposições e contrastes' (LAQUEUR, 2001; p. 17).
}

A grande produção científica sobre diferenças sexuais marcou a sociedade acadêmica e leiga nos séculos XVIII e XIX. Detalhes anatômicos foram investigados para se encontrar evidências científicas condizentes aos preceitos sociais existentes. Ossos, órgãos e tecidos de corpos masculinos e femininos foram analisados a partir de modelos comparativos (MARTIN, 2006; MARTINS, 2004). 
Ao longo da história as diferenças entre homens e mulheres despertaram interesses da ciência e da sociedade. Tais diferenças foram, e ainda são, naturalizadas e atribuídas às leis biológicas a partir de explicações reducionistas. Segundo Laqueur (2001):

\begin{abstract}
a visão dominante desde o século XVIII, embora de forma alguma universal, era que há dois sexos estáveis, incomensuráveis e opostos, e que a vida política, econômica e cultural dos homens e das mulheres, seus papéis no gênero, são de certa forma baseados nesses 'fatos' (LAQUEUR, 2001; p. 18).
\end{abstract}

Os desdobramentos teóricos acerca das diferenças sexuais ocorridos após "século das luzes" fortaleceu o discurso do senso comum, muitas vezes respaldado por argumentos da ciência, salientando a discriminação entre gêneros, reforçando a dominação masculina e colocando as mulheres em um patamar intelectual, psicológico e físico inferior aos homens (ROHDEN, 2003).

Na literatura biomédica da ciência moderna, por exemplo, o masculino esteve representado como norma e o feminino como desviante: seres imprevisíveis capazes de perverter a ordem do mundo em função de sua instabilidade (KRIEGER; FEE, 1994; MARTIN, 2006; MARTINS, 2004; ROHDEN, 2003).

De acordo com Rohden (2002) a mulher foi inicialmente tratada no discurso biomédico como eminentemente exclusiva à função sexual/reprodutiva e com base nessa visão biológica, foram definidos ou reforçados os papéis sociais - suas características anatômicas e fisiológicas às destinavam a maternidade, aos cuidados maternos e não às funções públicas. Diferentemente do homem, a mulher se afetaria mais com as mudanças da puberdade, gravidez e menopausa, governada por sua fisiologia instável e patologizante (MARTINS, 2004; ROHDEN, 2002; 2003). Em seus estudos, Martins (2004) e Rohden (2001) descrevem que as perturbações ginecológicas e vacilações de temperamento foram entendidas no discurso científico, e atualmente no senso comum, como sintomas inerentes ao desenvolvimento da genitalidade e da sexualidade feminina. 
No século XIX a idéia de que o desenvolvimento de uma sociedade saudável dependeria do monitoramento corporal e psicológico das mulheres construiu as bases para as ciências médicas, incluindo a ginecologia moderna, na medicina da mulher (ROHDEN, 2003). A noção de que as mulheres eram mais sensíveis às doenças e psicologicamente instáveis, estabeleceu a necessidade de uma especialidade para garantir que a fragilidade feminina inata e sua vulnerabilidade às influências externas não acarretassem danos à reprodução, pois se as capacidades reprodutivas fossem acometidas o percurso social também o seria.

Pretensamente, a Ginecologia, preocupada em gerenciar as funções do corpo feminino, definiu-se como a especialidade responsável pela regulação das manifestações corporais e sexuais da mulher, de modo que se a reprodução, como uma função biológica, fosse assegurada, poder-se-ia garantir também o papel social da mulher, ou seja, a maternidade, e, portanto, estaria mantida a ordem social vigente (AQUINO, 2005; ROHDEN, 2002; 2003). No decorrer da história, as sociedades impuseram critérios rígidos de comportamento para as compreensões e manejo sobre o corpo feminino. Nesse âmbito, as características que não corresponderam ao prescrito levaram muitas mulheres a serem marginalizadas diante da sociedade devido às suas práticas sexuais ou ideológicas (ROHDEN, 2002; 2003). Podemos deduzir disso que tal marginalização é uma forma de discriminação social e a busca de condutas adaptativas diante de tais prescrições se torna uma exigência geral, ainda vigente, às mulheres.

No período renascentista as ciências médicas representaram grande avanço no conhecimento sobre a natureza humana. Esse conhecimento esteve voltado para a dominação e controle e a sua finalidade era potencializar progresso e o bem estar dos seres humanos. Ao advogar pela dominação da natureza esse paradigma tinha como objetivo hierarquizar a relação com outras espécies e etnias consideradas inferiores, ou seja, 
aquelas incapazes de exercer o poder entre seus pares para conquistar espaço e reconhecimento (MARTINS, 2004).

Segundo Martins (2004), a natureza a ser dominada, foi e ainda é simbolizada pela figura feminina - a mãe natureza, ligada à feminilidade e a capacidade de fertilizar e gerar vida. A ciência moderna por sua vez foi historicamente simbolizada pela razão, o homem e sua capacidade racional para guiar a humanidade ao progresso através do controle das instâncias da natureza.

Assim, a ciência se configurou como atividade predominantemente masculina e como instrumento de subordinação das mulheres, para os cientistas da época a questão da identidade sexual era determinante e determinadora na vida dos indivíduos. As seguintes palavras de Francis Bacon ilustram esta concepção: "Alcancei a própria verdade levando a você a natureza com todos os seus filhos pra pô-la a seus serviços, e fazer dela a sua escrava" (BACON apud MARTINS, 2004, p. 22). Essa relação, mesmo que simbolicamente, representou as facetas de um contexto histórico, no qual se desenvolveu a humanidade, e em muito transposto até os dias atuais.

Convenções sociais guiaram o pensamento científico moderno, que se voltou para busca de respostas biológicas que redefiniram as relações de gênero na linguagem científica, formando assim uma estrutura ideológica capaz de subsidiar a diferenciação dos sexos e comprovar a suposta incapacidade inerente ao corpo feminino (MARTINS, 2004). Nesse momento histórico a natureza passou a justificar as relações de poder existentes, as desigualdades sociais, assim como a dominação de um gênero sobre o outro (MARTINS, 2004; ROHDEN, 2001; 2002; 2003).

Nas últimas décadas diversos estudos desvelaram as questões históricas que permeavam as relações de poder entre homens e mulheres. As repercussões do gênero sobre a vida dos indivíduos foram diversas e funcionaram como um fator impeditivo para 
que as mulheres se integrassem aos contextos acadêmicos até o final do século XIX (MORO, 2001; SCHIENBINGER, 2001). Os estudos de Moro (2001) e Schienbinger (2001) abordaram a realidade feminina referente ao engajamento e ocupação em atividades científicas. Uma vez que essas atividades científicas são entendidas como profissões de destaque e prestígio social, os autores investigaram os variados fatores que dificultaram o acesso da mulher em solos científicos e o quanto essa ausência feminina influenciou na ética e no posicionamento político das ciências no que se refere a igualdade de gênero. Magalhães e Ribeiro (2009) ao analisarem a rede de discursos das neurociências presentes em revistas de divulgação científica identificaram a presença de um forte investimento para reiterar as identidades hegemônicas sobre os modos de ser homem e ser mulher. O conteúdo, denominado científico dessas revistas, justifica as relações desiguais e legitimam as concepções hegemônicas do que é ser homem ou ser mulher (MAGALHÃES; RIBEIRO, 2009).

As contribuições dos estudos de Moro (2001), Schienbinger (2001), Martins (2004), Laqueur (2001), Rohden (2001) e Magalhães e Ribeiro (2009) denunciaram o quanto a ciência foi enviesada e enviesou seu olhar acerca das diferenças entre homens e mulheres. As determinações de papéis e espaços a serem ocupados parecem ter resultado nas diferenças quanto a forma como homens e mulheres lidam com seus corpos e com sua saúde e também na maneira como o homem e a mulher estão representados nos contextos de formação e atuação profissional na área da saúde.

\subsection{Estudos atuais sobre gênero e saúde}

Como já comentando, homens e mulheres lidam de maneira distinta com a saúde e com os cuidados corporais. Diversas áreas da ciência, tais como a antropologia, sociologia 
medicina e psicologia têm buscado descrever ou identificar relações causais entre a construção do gênero e a saúde física ou psicológica de homens e mulheres.

Os desdobramentos das discussões acerca do gênero e sua relação com a saúde da mulher ampliou o olhar das ciências para um aspecto relacional existente entre a distribuição de serviços destinados a homens e mulheres bem como na forma como lidam com as diversas instâncias em saúde. As questões de gênero que inicialmente discutiam a saúde da mulher passaram a ter como pauta a saúde do homem (GIFFIN, 2005; SCHRAIBER; GOMES; COUTO, 2005).

Alguns estudos focalizam, principalmente, a configuração da relação entre homens e mulheres e os serviços de saúde, bem como o manejo de indivíduos sobre seu corpo. No campo da saúde coletiva as pesquisas têm diversificado seu interesse de investigação procurando compreender as diferentes dimensões relativas à promoção da saúde. Recentemente, como ressalvam Gomes e Nascimento (2006) e Aquino (2006), certos estudos procuram investigar e discutir as especificidades do adoecer masculino, isto é, relacionar o gênero masculino às questões da saúde (CONNELL 1995; COURTENAY, 2000; FIGUEIREDO, 2005; KORIN, 2001; PINHEIRO et al., 2002; UNBEHANUM, 2003). Outros estudos analisam a história da medicalização do corpo feminino e também a relação das mulheres com os cuidados com a saúde (KRIEGER; FEE,1994; MARTINS, 2001; MENDONÇA et al., 2008; ROHDEN, 2007).

O perfil de morbidade ${ }^{11}$ acesso e uso de serviços de saúde é o eixo central de análise dos estudos de Pinheiro et al. (2002), Verbrugge (1982; 1989). Para esses autores o diferencial de mortalidade e morbidade entre os gêneros explica-se em parte pelas variações no perfil de necessidades de saúde entre os gêneros, incluindo-se as demandas associadas à gravidez, ao parto e a certas características fisiológicas. Na concepção de

\footnotetext{
${ }^{11}$ Em epidemiologia, morbidade é um indicador estatístico que define as relações normais e anormais de ocorrência de uma doença em determinada população e em um determinado momento, aferindo o comportamento de uma doença em um grupamento populacional (REY, 1999).
} 
Connell (1995), Doyal (2001), Gomes (2003) e Korin (2001) esse diferencial não pode ser analisado unicamente pelo viés biológico uma vez que os fatores biológicos e culturais atuam de forma multideterminada. Dessa forma, a relação entre gênero e saúde/adoecimento está tanto relacionada a fatores genéticos ou hormonais quanto a fatores psicológicos e sociais (BIRD; RIEKER, 1999; DOYAL 2001; MACINTYRE et al., 1996; MACINTYRE et al., 1999; SCHRAIBER; GOMES; COUTO, 2005; VERBRUGGE, 1982; 1989).

A pesquisa de Travassos et al. (2002), Pinheiro et al. (2002) e Korin (2001) indicam que a busca masculina por serviços de saúde é substancialmente inferior à busca realizada pelas mulheres, assim como existe uma visível diferença na atenção oferecida a homens e mulheres por esses serviços. Travassos et al. (2002) apontam que fatores tais como grau de escolaridade, nível social e grau de responsabilidade financeira para com a família também estão diretamente relacionados com a menor utilização masculina dos serviços de saúde. Ser homem, pertencer a classe baixa, estar empregado no setor informal da economia e ser chefe de família são os critérios que predispõe a menor utilização de serviços de saúde por parte dos homens. Além disso, os autores identificaram que as mulheres chefes de família também apresentam menor consumo desses serviços (TRAVASSOS et al., 2002). Nesse cenário, a necessidade em cuidar da saúde torna-se uma demanda predominantemente feminina e está distante do cotidiano masculino, especialmente de homens de menor poder aquisitivo e que não sofrem de doenças crônicas (TRAVASSOS et al., 2002; VERBRUGGE, 1989).

Ao longo da história as ciências médicas aproximaram as mulheres dos cuidados com a saúde de modo que nos dias atuais o maior envolvimento da mulher com a prevenção e com o cuidar é visto como algo espontâneo de sua natureza. Em relação aos cuidados com a saúde, os estudos apontam que embora vivam mais, as mulheres tendem a 
reportar mais morbidade e problemas psicológicos que os homens. Geralmente, a descrição dos sintomas é mais pontual e clara quando verbalizado por mulheres (ALVES; FIGUEIRAS, 2007; MANCINTYRE et al., 1996; MANCINTYRE; FORD; HUNT, 1999; VERBRUGGE, 1982; 1989). De modo geral, as mulheres consomem maiores quantidades de medicamentos, utilizam mais os serviços de saúde do que os homens de maneira preventiva e remediativa. Por um lado, isso parece resultar na situação de saúde desfavorável, quando se trata do grupo masculino e por outro configura em um excesso de uso medicamentoso de drogas por parte das mulheres (FIGUEIREDO, 2005; KORIN, 2001; MENDONÇA et al., 2008; PINHEIRO et al., 2002).

Nos estudos norte-americanos, as mulheres apresentam mais doenças crônicas do que os homens, porém tais acometimentos são menos severos. Os homens têm uma expectativa de vida ao nascer sempre menor quando comparada à das mulheres, e taxas de mortalidade por faixa etária apontam uma maior mortalidade masculina em todos os grupos etários (BIRD; RIEKER, 1999; MANCINTYRE et al., 1996; MANCINTYRE et al., 1999; PINHEIRO, et al., 2002; VERBRUGGE, 1982; 1989).

As pesquisas brasileiras corroboram com as americanas e européias ao demonstrar que há um número maior de homens internados em situação grave, e em geral, os homens vivem menos que as mulheres, morrem em maior quantidade e mais cedo em relação à população feminina (FIGUEIREDO, 2005; PINHEIRO et al., 2002). Pinheiro et al. (2002) discutem que os fatores de risco associados a problemas de saúde variam segundo o gênero:

[...] Enquanto a obesidade, o stress, a infelicidade e as pressões ligadas aos papéis sociais exercidos pelas mulheres são apresentadas como fatores que aumentam os riscos de doenças neste grupo, entre homens há maior ocorrência de fumo, ingestão de álcool e desvantagens em situações relacionadas ao trabalho, acarretando aumento de riscos de problemas no longo prazo (PINHEIRO et al., 2002, p.688). 
Estudos epidemiológicos no âmbito da saúde mental apontam que as mulheres apresentam índices mais altos nas categorias de diagnóstico de psicopatologias, dentre elas estão em destaque os transtornos de humor, de ansiedade, de adaptação, fobias etc. No caso dos homens, perturbações como o alcoolismo, abuso de drogas e desordem antisocial, apresentam incidências maiores. A pesquisa atual em Psicologia e saúde mental aponta fatores que, numa construção psicossocial do gênero, influenciam inevitavelmente a forma de expressão da saúde mental (RABASQUINHO; PEREIRA, 2007). A forma como cada indivíduo manifesta sua queixa está sujeita às regras sobre o que é socialmente permitido e esperado para cada gênero no momento e no decorrer histórico sob o qual se constrói tais regras e através do qual se incorporam culturalmente determinadas normas (ALVES; FIGUEIRAS, 2007).

O Suplemento Saúde da Pesquisa Nacional por Amostra de Domicílios (Pnad), no Brasil, aponta que aproximadamente $23,5 \%$ das mulheres em comparação a $18,2 \%$ dos homens auto-avaliaram seu estado de saúde como 'regular', 'ruim' ou 'muito ruim'; 7\% entre as mulheres e 5,6\% entre os homens se referem a uma atual restrição de atividades rotineiras por motivo de saúde (MINISTÉRIO DA SAÚDE, 2004). Outro fator que reafirma as discussões estrangeiras sobre esse tema é o maior interesse das mulheres em relação à sua saúde; em todas as faixas etárias, elas tendem a relatar mais condições precárias de saúde e assumir a manifestação de doenças crônicas do que entre os homens (MINISTÉRIO DA SAÚDE, 2004; VERBRUGGE, 1989). Para a compreensão dessa discussão, os autores sugerem que homens são menos propensos a reportar problemas de saúde ao seu grupo de apoio e aos profissionais da saúde (CONNELL, 1995; COSTAJÚNIOR; MAIA, 2009; GOMES, 2003; KORIN, 2001; MACINTYRE et al., 1999).

O distanciamento masculino, no que diz respeito aos cuidados com a saúde, principalmente os relativos a aspectos preventivos, de adesão ao tratamento e o 
engajamento em situações de risco, atuam negativamente sobre os índices de mortalidade masculina (COURTENAY, 2000; DOYAL，2001; GAWRYSZEWSKI; KOIZUMI; MELLO-JORGE, 2004; VERBRUGGE, 1982). O risco de um homem se envolver em um evento fatal, sendo esse intencional ou não intencional, é maior que o da mulher. Comportamentos tidos como violentos e danosos, tais como o homicídio e suicídio, também ocorrem com maior freqüência entre os homens, e, geralmente levam a morte ou hospitalização dos indivíduos envolvidos (GAWRYSZEWSKI; KOIZUMI; MELLOJORGE, 2004).

Historicamente a mulher é tida como um ser voltado para o cuidado, para a delicadeza e o cuidado do lar, ao passo que se constrói e modela uma imagem masculina voltada para a força e a onipotência. Costa-Junior e Maia (2009) investigaram a concepção de homens hospitalizados sobre os cuidados com a saúde e o tratamento de doenças e Gomes, Nascimento e Araújo (2007) analisaram as explicações de homens sobre a pouca procura por serviços de saúde. Os resultados desses estudos revelaram que as possíveis dificuldades dos homens em verbalizar as próprias fragilidades em relação à sua saúde, remetem ao temor em demonstrarem fraqueza perante os outros ou em sugerir a idéia de feminilização associada aos cuidados de saúde. Além disso, também ratificam que determinados comportamentos de homens em relação à saúde corporal estão relacionados ao modelo de masculinidade; daí a negação, omissão ou ocultação sobre as necessidades de cuidados em saúde, por parte de muitos homens e consequente diminuição de procura por assistências médicas.

Costa-Junior e Maia (2009) apresentam indicativos de que tanto a socialização diferencial vivida por homens e mulheres, quanto a estrutura dos serviços de saúde podem influenciar na maneira como homens cuidam de sua saúde. Conscientes de sua baixa procura por seguimentos preventivos em saúde, os homens entrevistados no estudo, 
reconhecem que a cultura atual disponibiliza mais informações sobre saúde às mulheres e também dá maior suporte para que essas procurem os serviços de saúde.

Outro indicativo importante desses estudos consiste no fato de que o público masculino somente busca por atendimento em saúde quando os sintomas ocasionam no comprometimento de seu desempenho cotidiano (COSTA-JÚNIOR; MAIA, 2009; GOMES; NASCIMENTO; ARAÚJO, 2007). Como argumenta Korin (2001) os homens sentem-se incômodos com a situação passiva e dependente do papel de doente, e isso contribui para que ignorem sinais de alarme e procurem ajuda quando sua saúde já está comprometida.

Braz (2005) e Figueiredo (2005) analisaram a distribuição de serviços voltados para o público masculino e a demanda por eles. Os autores afirmam que homens preferem utilizar serviços de saúde como farmácias ou prontos socorros, ainda que, tais serviços não direcionem programas específicos. Segundo Figueiredo (2005), nesses locais os homens seriam atendidos mais rapidamente e poderiam revelar, de forma breve e superficial, seus problemas de saúde. Entretanto, devemos considerar que embora os autores remetam a incorporação do padrão masculino como um indício de pouca procura por assistência médica e por atitudes de cuidados preventivos em relação à saúde, o acesso aos espaços de serviços básicos de saúde são dificultados à essa população; há limites impostos pela estrutura dos serviços públicos e seus escassos programas preventivos de saúde dirigidos aos homens (BRAZ, 2005; COSTA-JUNIOR; MAIA, 2009; FIGUEIREDO, 2005).

Fatores associados ao emprego e a competitividade no mercado de trabalho aparecem nas pesquisas como uma variável que atrapalha os homens a buscarem por atendimento médico. $\mathrm{O}$ contexto de trabalho, tal como posto em nossa sociedade, não seria receptivo às manifestações de doenças por parte dos homens, uma vez que se afastar do trabalho por motivos de doença poderia ocasionar em um desmerecimento do homem 
enquanto inapto para suas atividades laborais (COSTA-JÚNIOR; MAIA, 2009; GOMES; NASCIMENTO; ARAÚJO, 2007). Uma vez que a fragilidade física é um atributo feminino as faltas das mulheres no trabalho, ocasionadas pela procura de serviços de saúde não produziriam tanto desconforto tampouco seria motivo de descrédito. Do mesmo modo a maternidade tipificada ao feminino, permite no mundo do trabalho que as mulheres tenham mais facilidade em se ausentar de suas atividades. No entanto, essa recíproca não parece ser verdadeira para os homens. O fato de as mulheres poderem levar seus filhos nos atendimentos em saúde, por exemplo, é apontando nos estudos como mais um fator que aproxima esse público aos serviços de saúde (PINHEIRO, et al., 2002).

No Brasil há esforços políticos que geraram benefícios às mulheres e no âmbito da saúde coletiva produziu a criação de programas de assistência integral à saúde da mulher. Tais programas pautados na necessidade de retirar a mulher da esfera meramente reprodutiva incluíram novas temáticas, tais como a sexualidade, a violência e o trabalho (AQUINO, 2005). O debate ainda recente sobre a masculinidade e seu papel na configuração da saúde do homem também começaram a produzir um movimento para que novas políticas sejam planejadas de modo a considerar esse público e suas peculiaridades. No entanto, Aquino (2005) nos aponta que a grande parte da produção acadêmica da medicina acerca da saúde do homem, pode produzir nos leitores desavisados uma sensação de dejá $v u$. Isto porque tais produções retomam aquelas mesmas pautas que restringiam a saúde feminina nos âmbitos reprodutivos e sexuais e que agora com o desenvolvimento tecnológico da indústria farmacêutica tendem a agregar o uso de medicamentos para fins de manutenção da saúde sexual ou reprodutiva. Nas palavras de Aquino (2005):

não se trata de recusar o desenvolvimento científico e tecnológico e o acesso universal a quem possa dele se beneficiar (...) entretanto os interesses da indústria farmacêutica convergem em última instância para a produção de mais valia e seus programas de pesquisa sobre novas drogas se baseiam em predições 
de futuros mercados e no potencial de criação de produtos lucrativos (AQUINO, 2005, p. 21)

Nesta direção a produção científica ainda induz a uma medicalização do homem e poucos esforços financeiros são dispendidos no sentido de promover políticas de inserção dos homens na assistência integral a saúde tal como se tem com as mulheres.

O excesso de medicamentos utilizados pelas mulheres foi e ainda é uma questão de saúde pública. Mendonça et al. (2008) interessados em investigar a interação entre gênero e consumo de calmantes (benzoadiazepínicos) observaram que há uma estreita relação entre a condição social da mulher e o uso destes medicamentos. Nesse estudo, os fatores familiares e a necessidade de corresponder às demandas sociais foram os principais fatores que aproximam as mulheres do uso desse psicotrópico e a maneira como os médicos disponibilizam as informações e prescrições dos remédios facilitam o seu abuso. Gomes (2008) propõe a seguinte reflexão de Ivan Illich (1975):

\footnotetext{
a medicalização perniciosa aliena os meios de tratamento, faz com que o conhecimento científico não seja partilhado, torna o consumidor de cuidados impotente para se curar ou curar os outros e apresenta como "álibi o poder de encher suas vítimas com terapias que elas foram ensinadas a desejar" (ILLICH, 1975 apud GOMES, 2008).
}

Nesse sentido parece ser errôneo conduzir a saúde masculina para os caminhos da medicalização, principalmente se considerarmos que as demandas da saúde do homem são basicamente constituídas pela natureza social e histórica que permeiam as questões de gênero. Alguns estudiosos afirmam que o gênero deve ser visto como fator altamente influente na caracterização dos padrões de morbi-mortalidade. Na construção de gênero, muitos homens assumem riscos que interferem em suas condições de saúde e as mulheres, por vezes, aceitam constrangimentos e o excesso de procedimentos impostos sobre o seu corpo (GOMES; NASCIMENTO; ARAÚJO, 2007; KORIN, 2001; MARTINS, 2004; ROHDEN, 2001; 2003). 
Retomando, podemos concluir que caracterizado como padrão de saúde, o corpo masculino permanece fora do olhar das ciências da saúde, o que talvez tenha contribuído para que a exposição do próprio corpo e da saúde seja mais difícil para os homens. Culturalmente o corpo masculino ainda é visto como um corpo designado ao trabalho e a promoção do desenvolvimento social. A idéia de corpo forte, viril e resistente, permeia a concepção de masculino na sociedade atual (COSTA-JUNIOR; MAIA, 2009; GOMES; NASCIMENTO; ARAÚJO, 2007).

Há, portanto, um conjunto de expressões que representam modelos hegemônicos e estereotipados de feminilidade e masculinidade. Segundo Connell (1995) o modelo masculino, revela e mantêm, características comportamentais em torno da posição dos homens na estrutura das relações de gênero como, por exemplo, maior atividade, desempenho, força física, resistência, independência, etc. As características não enquadradas nesse padrão são, em geral, avaliadas negativamente entre os membros de nossa sociedade uma vez que podem ser consideradas não-masculinas, tipicamente femininas ou relativas a homossexuais efeminados (CONNELL, 1995; NOLASCO, 1993).

No contexto atual, pesquisas apontam uma situação de saúde desfavorável para os homens, contrapondo desta forma a noção de invulnerabilidade do corpo masculino (CONNELL, 1995; GOMES, 2003). Tais pesquisas demonstram que os homens vivem menos tempo do que as mulheres e morrem em maior quantidade em relação à população feminina. Em alguns países americanos os estudos revelam que a população masculina tem uma expectativa de vida ao nascer sempre menor quando comparada à das mulheres; e as taxas de mortalidade por faixa etária apontam uma sobre mortalidade masculina em todos os grupos etários (FIGUEIREDO, 2005; PINHEIRO et al., 2002).

Autores como Macintyre; Ford; Hunt (1999) e Verbrugge (1989) sugerem que homens são menos propensos a reportar problemas de saúde ao seu grupo de apoio e aos 
profissionais da saúde enquanto há uma grande procura feminina aos serviços de saúde. É notável a maior disposição de serviços e programas voltados ao público feminino, sendo estes tanto para atendimento médico ou para realização de exames preventivos. Os homens, de modo geral, recorrem a farmácias ou pronto-socorros (BRAZ, 2005) e relatam não se sentirem acolhidos nos serviços de saúde disponíveis (GOMES; NASCIMENTO; ARAÚJO, 2007; FIGUEIREDO, 2005).

A literatura indica que as mulheres parecem desenvolver uma relação de cuidados com sua saúde maior e mais freqüente (FIGUEIREDO, 2005; GOMES, 2003; KORIN, 2001; NOLASCO, 1993; PINHEIRO et al., 2002) e que há diversas influências negativas relacionadas ao cuidado da saúde masculina e pouca atenção por parte dos serviços de saúde em atender essa demanda (CONNELL, 1995). Outras pesquisas apontam que mulheres utilizam medicamentos em excesso (terapias hormonais e psicotrópicos) e se sujeitam a procedimentos cirúrgicos desnecessários (MARTINS, 2001; MENDONÇA et al., 2008).

Os estudos citados têm contribuído para a reflexão e problematização dos aspectos relativos à saúde da população no âmbito das questões de gênero. A partir da revisão da literatura, considerando as pesquisas e a complexidade da construção de gênero ao longo da história, nos propomos a estudar o relato de enfermeiras/os e médicas/os sobre a relação das questões de gênero na saúde de homens e mulheres. Essa investigação nos pareceu uma questão fundamental para a produção de conhecimentos abrangentes que possam contribuir para a reflexão acerca da formação profissional daqueles que, de certa forma, compõem em sua grande maioria o atendimento em saúde e que podem também reproduzir as relações de gênero em sua prática profissional. Ressaltamos que o recorte do estudo se limita a duas práticas profissionais na área da saúde devido ao tempo disponível para a conclusão da pesquisa e também pelos objetivos propostos e no delineamento do 
método desse estudo. Na seqüência, apresentamos os objetivos, o delineamento do método da pesquisa e a análise preliminar dos resultados obtidos. 


\section{OBJETIVOS}

Objetivos Gerais

Investigar, por meio dos relatos de profissionais da saúde, as suas concepções ${ }^{12}$ sobre gênero e sobre as relações entre gênero e os cuidados com a saúde.

Objetivos Específicos

- Identificar e analisar as concepções de médicos/as e enfermeiros/as sobre o gênero masculino e o feminino;

- Identificar e analisar a compreensão de médicos/as e enfermeiros/as sobre a influência de padrões de gênero em relação aos comportamentos de seus pacientes com os cuidados com a saúde e com a prevenção e tratamento de doenças;

- Analisar a influência das questões de gênero sobre a prática de médicos/as e enfermeiros/as no atendimento a pacientes homens e mulheres em unidades de atenção secundária e terciária.

\section{PERCURSO METODOLÓGICO}

Esta pesquisa se classifica como um estudo qualitativo e descritivo e de caráter investigativo. Essa metodologia mostra-se indicada para atender os objetivos pretendidos uma vez que é considerada por alguns autores, como Gomes (2008) e Minayo (2006), como um meio eficaz para se obter informações sobre fenômenos psicológicos e sociais na área da saúde.

Todos os procedimentos éticos prescritos para pesquisas com seres humanos foram respeitados, sendo o projeto inicial submetido a um Conselho de Ética em Pesquisa no qual recebeu aprovação para sua realização (Processo de número 627/46/01/08 com parecer favorável em anexo - anexo 1). Além disso, esse projeto de pesquisa também foi

${ }^{12}$ Entendemos que as concepções se referem aos pontos de vista, opiniões ou compreensões, decorrentes da história de aprendizagem de um indivíduo, sobre um determinado fenômeno. 
apresentado à Comissão Científica da instituição hospitalar onde se realizaram as entrevistas para sua autorização ${ }^{13}$.

\section{Participantes}

Participaram do estudo 11 profissionais da saúde de ambos os sexos, com formação superior que atuavam na área da saúde por no mínimo 01 ano. Todos os profissionais trabalhavam na mesma instituição, sendo 06 profissionais da Enfermagem e outros 05 da Medicina. Desses, sete eram mulheres e 04 homens. Entre os profissionais de Enfermagem entrevistados 03 atuavam em unidade de internação e 03 em ambulatórios de especialidades do hospital. No total dos/as médicos/as entrevistados 04 profissionais atuam em especialidades clínicas e 01 atua como cirurgiã especialista. O Quadro 1 abaixo apresenta os dados de caracterização dos participantes.

Quadro 1 - Caracterização dos participantes.

\begin{tabular}{|llllcc|}
\hline & Sexo & Idade & $\begin{array}{l}\text { Formação } \\
\text { e atuação }\end{array}$ & $\begin{array}{c}\text { Tempo de trabalho na } \\
\text { instituição/unidade }\end{array}$ & Tempo de formação \\
\hline E1 & F & 40 a. & Enfermeira* & 05 anos & 18 anos \\
\hline E2 & F & 35 a. & Enfermeira $* *$ & 05 anos & 10 anos \\
\hline E3 & F & 31 a. & Enfermeira $* *$ & 05 anos & 07 anos \\
\hline E4 & M & 30 a. & Enfermeiro $* *$ & 01 e 06 meses & 02 anos \\
\hline E5 & F & 26 a. & Enfermeira* & 04 anos & 05 anos \\
\hline E6 & M & 30 a. & Enfermeiro* & 01 e 06 meses & 03 anos \\
\hline M1 & F & 35 a. & Médica*** & 06 anos & 11 anos \\
\hline M2 & F & 37 a. & Médica*** & 05 anos & 09 anos \\
\hline M3 & M & 36 a. & Medico*** & 04 anos & 05 anos \\
\hline M4 & M & 30 a & Medico*** & 01 ano e 06 meses & 03 anos \\
\hline M5 & F & 40 a. & Medica*** & 05 anos & 10 anos \\
\hline
\end{tabular}

(*) Profissional de unidade de internação; (**) Profissional de unidade ambulatorial; (***) Profissional clínico/ cirurgião - especialista.

\footnotetext{
${ }^{13}$ Informamos que o documento de aprovação emitido pelo comitê de ética da instituição não será apresentado em anexo para resguardar o sigilo dos participantes e a identificação da instituição hospitalar.
} 
A opção por selecionar os profissionais atuantes em unidades de atendimento secundário e terciário em saúde (ambulatório e unidades de internação hospitalar), visou delimitar aqueles profissionais na área da saúde que estivessem em contato direto e cotidiano com o atendimento de homens e mulheres, diante de questões de diagnóstico, tratamento e acompanhamento. E, para controlar a influência de outras variáveis, optamos por restringir os profissionais da área da saúde em dois grupos: enfermeiros/as e médicos/as ${ }^{14}$.

O grupo, de enfermeiros/as foi constituido por se tratar de profissionais que têm uma formação ampla em relação aos cuidados com a saúde e doença e que lidam com diferentes demandas em saúde, antes, durante e depois de um possível período de intervenção médica. O outro grupo, de médicos/as, foi definido, por se tratar de profissionais que têm uma formação especialista em determinada área e que lidam de modo específico de acordo com as demandas e graus de adoecimento, ou seja, em situações de diagnósticos e terapêuticas tais como tratamentos e procedimentos cirúrgicos.

As unidades ambulatoriais visam o atendimento, diagnóstico e acompanhamento de pacientes, sendo interações de curto período voltadas para coleta de informações e de instruções. Já nas unidades de internação a relação entre profissional e paciente é habitualmente caracterizada por interações mais longas e de maior envolvimento no que tange as demandas pessoais dos pacientes. Cabe ressaltar que diferentemente dos/as enfermeiro/as, a interação entre médico/a e paciente ocorre com maior frequência nos ambulatórios durante as consultas uma vez que nas unidades de internação, essa interação, geralmente, se restringe em contatos rápidos compartilhados com os acompanhantes do paciente.

\footnotetext{
${ }^{14}$ Lembramos que os profissionais da saúde envolvem diferentes modalidades acadêmicas e especialidades, como por exemplo, médicos, psicólogos, assistentes sociais, enfermeiros, dentre outros.
} 
Estudos feitos na área da saúde tais como os de Andrade-Lopes (2003), AndradeLopes, Combinato e Reali (2004) e Costa-Junior e Andrade-Lopes (2007) sugerem que a formação do profissional e o contexto de trabalho influenciam na interação entre usuários e profissionais. A exemplo disto temos o tempo de duração da interação entre profissional e paciente e a formação acadêmica que pode enfatizar ou não estratégias de abordagem humanizada e individualizada ao paciente. Por esse motivo optamos em recrutar profissionais de duas formações acadêmicas que atuam nestes diferentes setores.

\section{Material: Instrumento de coleta de dados}

Para a coleta de dados utilizou-se um roteiro de entrevista semi-estruturado, previamente elaborado pelo pesquisador e testado em sua funcionalidade em situação piloto. Segundo Manzini (1991), na entrevista classificada como semi-estruturada a resposta do entrevistado não está condicionada a uma padronização de alternativas formuladas pelo pesquisador. Essa modalidade de entrevista está focalizada em um objetivo sobre o qual se confecciona um roteiro com questões principais que são complementadas por outras perguntas pertinentes às circunstâncias momentâneas da entrevista. A entrevista semi-estruturada pode ser constituída de questões abertas e/ou fechadas desde que tais questionamentos estejam pautados em teorias e hipóteses que se relacionem com o tema investigado (MANZINI, 2004; ROSA; ARNOLDI, 2006).

A opção pela utilização da entrevista ocorreu porque além de partir de questionamentos gerais, ela também oferece a possibilidade de formulação de novas hipóteses e novos questionamentos, podendo até mesmo facilitar o dinamismo da interação e o aprofundamento no relato de concepções subjetivas por parte do entrevistado (CAMPOS, 2000; COZBY, 2003; MANZINI, 2004; ROSA; ARNOLDI, 2006). Ainda, a bibliografia consultada evidencia que tal instrumento permite coletar dados relevantes 
para as pesquisas qualitativas na área da saúde (COSTA-JUNIOR; ANDRADE-LOPES 2007; GOMES, 2008; GOMES; NASCIMENTO; ARAÚJO, 2007; MINAYO, 2006).

De acordo com um modelo geral de entrevista semi-estruturada, o roteiro de entrevista foi organizado em três blocos temáticos. Os temas dos blocos sumarizavam o tópico a ser investigado: 1- Concepção de masculino e feminino; 2 - Gênero e Comportamentos de cuidados com a saúde e 3 - Atuação profissional na área da saúde e questões de gênero, atendendo aos objetivos do estudo. O Quadro 2 apresenta as questõeschave do roteiro de entrevista com os profissionais da saúde distribuídas nos três blocos temáticos. 
Quadro 2 - Roteiro de entrevista aplicado com os profissionais da saúde.

\begin{tabular}{|c|c|}
\hline BLOCOS & QUE \\
\hline $\begin{array}{l}\text { 1- Concepção de masculino e } \\
\text { feminino } \\
\text { Objetivos: investigar o que os } \\
\text { profissionais compreendem como gênero, } \\
\text { ou seja, noções de masculino e feminino e } \\
\text { as relações de gênero na sociedade. }\end{array}$ & $\begin{array}{l}\text { O que você entende por gênero? } \\
\text { O que caracteriza, para você, o feminino? } \\
\text { O que caracteriza, para você, o masculino? } \\
\text { Por que você pensa desta forma? / Como chegou a essas } \\
\text { conclusões? }\end{array}$ \\
\hline $\begin{array}{l}\text { 2- Gênero e Comportamentos de } \\
\text { cuidados com a saúde } \\
\text { Objetivos: investigar das idéias, teorias ou } \\
\text { hipóteses que os depoentes têm sobre a } \\
\text { influência do gênero em relação à } \\
\text { prevenção e aos cuidados com a saúde. }\end{array}$ & $\begin{array}{l}\text { Na sua opinião, entre homens e mulheres, quem cuida e se } \\
\text { preocupa mais com a saúde? Por quê? } \\
\text { Na sua opinião, entre homens e mulheres, quem está mais } \\
\text { predisposto a ter problemas de saúde e ficar doente? Por } \\
\text { quê? } \\
\text { Na sua opinião, entre homens e mulheres, quem assume } \\
\text { melhor o tratamento médico indicado? } \\
\text { Na sua opinião, entre homens e mulheres, quem se cura } \\
\text { mais de uma doença? Por quê? }\end{array}$ \\
\hline $\begin{array}{l}\text { 3- Formação e atuação profissional } \\
\text { na área da saúde e questões de } \\
\text { gênero } \\
\text { Objetivos: coletar informações sobre a } \\
\text { prática profissional que se relaciona com } \\
\text { as demandas masculinas e femininas, bem } \\
\text { como as idéias que os entrevistados têm } \\
\text { quanto a interação com pacientes homens } \\
\text { e pacientes mulheres. Esse bloco também } \\
\text { pretendeu investigar a prática profissional } \\
\text { e a formação acadêmica, visando conhecer } \\
\text { se as concepções dos participantes } \\
\text { poderiam basear-se em discussões sobre } \\
\text { gênero obtidas em seus respectivos cursos } \\
\text { de formação. }\end{array}$ & $\begin{array}{l}\text { Pensando nas pessoas que você atende ou atendeu na sua } \\
\text { atuação profissional } \\
\text { Você acha que ser mulher ou homem influencia em } \\
\text { relação às atitudes de seus pacientes durante o seu } \\
\text { atendimento? (Explique) } \\
\text { Quando você atende um homem, você faz algum } \\
\text { procedimento específico para lidar com as características } \\
\text { deles? (Você faz alguma coisa diferente porque são } \\
\text { clientes homens?). } \\
\text { Quando você atende uma mulher, você faz algum } \\
\text { procedimento específico para lidar com as características } \\
\text { delas? (Você faz alguma coisa diferente porque são } \\
\text { clientes mulheres?). } \\
\text { Você acha mais difícil atender/ cuidar, tratar de uma } \\
\text { pessoa quando ela é mulher ou homem ou não há } \\
\text { diferença? Por quê? } \\
\text { Na sua formação, você estudou sobre questões de gênero/ } \\
\text { características de homens e mulheres e relação disso com } \\
\text { a saúde/doença? (se sim, o que e como; se não, o que } \\
\text { pensa disso? Seria importante e por quê?). }\end{array}$ \\
\hline
\end{tabular}

\section{Procedimento de coleta e análise dos dados}

Os dados da pesquisa foram coletados em um hospital público de grande porte de uma cidade do interior do estado de São Paulo. Após o contato com a instituição, a apresentação do projeto de pesquisa e da obtenção de autorização para sua realização é que se iniciou a coleta de dados. 
Os participantes foram convidados para participar da pesquisa sob os seguintes critérios de inclusão: a) ter curso de graduação concluído; b) atuar na mesma instituição; c) ser Médico/a ou Enfermeiro/a integrante de unidade ambulatorial ou unidade de internação que atende usuários de ambos os sexos; d) ter experiência profissional mínima de um ano; e) aceitar voluntariamente a participação.

Diante desses critérios e de uma lista de profissionais que poderiam participar, em horário e dia agendado previamente, o pesquisador foi à instituição e falou pessoalmente com os profissionais convidando a participarem da pesquisa. Para todos eles, os objetivos gerais da pesquisa e o convite para participação foram feitos de modo esclarecedor e ético.

Todos os profissionais convidados aceitaram participar (apenas um dos profissionais não dispunha de tempo para a entrevista). Para a entrevista um novo horário e dia foi agendado com cada participante de modo a respeitar o que fosse o mais conveniente para eles. As entrevistas foram realizadas em local reservado, em geral, uma sala da área hospitalar onde atuavam, com privacidade necessária para a interação entre pesquisador e participante.

No momento da entrevista, os participantes, mais uma vez, foram esclarecidos sobre a pesquisa e assinaram o termo de consentimento informado, respeitando-se os procedimentos éticos em pesquisa com seres humanos (informação, esclarecimento, solicitação de consentimento). Um modelo de termo de consentimento encontra-se no apêndice 1 .

Os dados das entrevistas foram registrados por áudio-gravação e transcritas de modo integral de acordo com os blocos temáticos para posterior análise. A elaboração da entrevista em blocos temáticos baseados nos dados na revisão bibliográfica e nos objetivos do estudo estabeleceu pré-categorias que contribuiram no agrupamento dos dados nas categorias e subcategorias para a realização da análise. 
A transcrição do relato permitiu o agrupamento das falas em categorias e subcategorias para a realização da análise de conteúdo, tal como propõe Bardin (1979). De acordo com Bardin (1979) a análise de conteúdo é um método de tratamento de dados amplamente utilizado nas ciências humanas e sociais, principalmente no que diz respeito a relatos verbais. A análise de conteúdo se executa a partir de três etapas: 1) Leitura e préanálise; 2) agrupamento e exploração do material e 3) tratamento dos resultados: a inferência e a interpretação de acordo com a literatura examinada. Essas etapas foram seguidas para responder as questões de investigação desta pesquisa.

Baseando-se nos relatos dos participantes, obtidos na entrevista, o conteúdo temático foi agrupado em categorias e subcategorias. O Quadro 3 a seguir descreve as categorias e subcategorias elaboradas para análise. 


\begin{tabular}{|c|c|c|}
\hline Categoria & Subcategorias & Descrição da categoria \\
\hline \multirow{4}{*}{$\begin{array}{l}\text { 6.1 Concepções } \\
\text { de gênero: o } \\
\text { masculino e o } \\
\text { feminino }\end{array}$} & $\begin{array}{l}\text { Gênero como } \\
\text { agrupamento ou } \\
\text { diferenciação sexual }\end{array}$ & $\begin{array}{l}\text { Relatos sobre as características } \\
\text { atribuídas ao masculino e feminino, a } \\
\text { partir das questões de gênero. }\end{array}$ \\
\hline & $\begin{array}{l}\text { Características } \\
\text { comportamentais }\end{array}$ & $\begin{array}{l}\text { Relatos sobre os comportamentos e } \\
\text { atitudes do indivíduo que podem } \\
\text { repercutir em seu ambiente social. }\end{array}$ \\
\hline & Características Sociais & $\begin{array}{l}\text { Relatos sobre os fatores que se } \\
\text { relacionam diretamente com as normas, } \\
\text { práticas e valores presentes no contexto } \\
\text { familiar, profissional e também na } \\
\text { cultura. }\end{array}$ \\
\hline & $\begin{array}{l}\text { Características } \\
\text { Físicas }\end{array}$ & $\begin{array}{l}\text { Relatos sobre os aspectos corporais, } \\
\text { anatômicos, fisiológicos ou genéticos } \\
\text { atribuídos como características de um ou } \\
\text { outro sexo e que se relacionam com a } \\
\text { saúde. }\end{array}$ \\
\hline \multirow[t]{2}{*}{$\begin{array}{l}6.2 \text { Gênero e } \\
\text { Comportamentos } \\
\text { de cuidados com } \\
\text { a saúde }\end{array}$} & $\begin{array}{l}\text { Comportamentos de } \\
\text { cuidados com a saúde e } \\
\text { doença em função do } \\
\text { gênero }\end{array}$ & $\begin{array}{l}\text { Relatos das concepções sobre o hábito } \\
\text { de cuidar da saúde, tanto em aspectos } \\
\text { preventivos, quanto aos aspectos } \\
\text { terapêuticos, tais comor tomar } \\
\text { medicamentos e seguir as prescrições } \\
\text { dos profissionais da saúde. }\end{array}$ \\
\hline & $\begin{array}{l}\text { Compreensão de como } \\
\text { e por que mulheres e } \\
\text { homens cuidam da } \\
\text { saúde e lidam com a } \\
\text { doença e com o } \\
\text { tratamento }\end{array}$ & $\begin{array}{l}\text { Relatos das concepções sobre os } \\
\text { cuidados com o corpo e as formas como } \\
\text { homens e mulheres lidam com os } \\
\text { tratamentos e com suas doenças. }\end{array}$ \\
\hline \multicolumn{2}{|c|}{$\begin{array}{l}\text { 6.3 Atuação cotidiana no atendimento a } \\
\text { homens e a mulheres }\end{array}$} & $\begin{array}{l}\text { Relatos sobre as interações entre homens } \\
\text { e mulheres na prática diária: } \\
\text { atendimento e acompanhamento, } \\
\text { procedimento terapêutico ou na } \\
\text { solicitação de exames de saúde. }\end{array}$ \\
\hline \multicolumn{2}{|c|}{$\begin{array}{l}\text { 6.4 Formação acadêmica relacionada às } \\
\text { questões de gênero }\end{array}$} & $\begin{array}{l}\text { Relatos sobre a presença ou ausência de } \\
\text { debate das questões de gênero durante a } \\
\text { formação acadêmica. }\end{array}$ \\
\hline
\end{tabular}




\section{RESULTADOS}

Os resultados serão apresentados a partir da descrição das categorias temáticas, seguido de exemplos de fragmentos dos relatos dos participantes. Os participantes serão identificados pela letra "M", quando profissional da área da medicina e pela letra "E", quando profissional da área da enfermagem e, ainda, pelas letras $\mathrm{F}$, quando se tratar de uma pessoa do sexo feminino e pela letra $\mathrm{M}$, quando do sexo masculino. A idade do/da participante estará inserida nas respectivas identificações.

\subsection{Concepções de gênero: o masculino e o feminino}

Entre os entrevistados as características de homens e mulheres foram citadas referindo-se, principalmente, aos comportamentos e sentimentos e não ao corpo físico e, em todos os casos, as vantagens do feminino foram ressaltadas em comparação ao masculino. A seguir apresentamos a descrição dos sub-agrupamentos dessa categoria.

\subsubsection{Gênero como agrupamento ou diferenciação sexual}

Para os Enfermeiros/as E1(F), E2(F), E3(F), E4(M), E5(F) e E6(M) e também para os Médicos/as M1(F), M2(F); M3(M) e M5(M) a compreensão do termo gênero se refere a uma forma de diferenciar ou agrupar os objetos ou seres vivos em categorias tais como etnia ou espécie e representando um modo de diferenciar os seres humanos em masculino e feminino. Nos exemplos dos relatos a palavra gênero:

seria pra diferenciar uma espécie da outra (E1, F, 40a);

a classificação de uma determinada palavra, um determinado tipo. Gênero feminino e gênero masculino. Quando você fala gênero: a xícara, o prato, artigo definido. É o que me vem à mente (M2, F, 37a);

acredito que gênero seria mais uma distinção entre as raças, por exemplo: homem e mulher, branco, negro etc (E2, F, 35a); 
gênero é uma diferença entre uma coisa e outra. A maioria das pessoas usa o gênero pra diferenciar, o masculino e o feminino. Ou alguma outra coisa, racial, branco, preto ou pardo (E4, M, 30a);

primeira coisa que eu penso em gênero é gênero masculino e feminino (M3, M, 36a);

Em distinção sexual, foi o que eu pensei em gênero mesmo: homem, mulher, masculino e feminino (E5, F, 26a);

Gênero? [silêncio]. Para mim é o masculino e o feminino (M1, F, 35a);

é uma categoria, de um grupo, de uma classe (...) Pontua o que é diferente entre aquele grupo, entre os grupos, e o que é comum dentro daquele gênero" (M5, F, 37a);

o que eu entendo que seja gênero, é as condições que cada um tem, as particularidades de cada um, o jeito de pensar, de agir, eu acredito que tenha a ver com gênero (...) O comportamento que o homem tem, por exemplo, escarrar na rua é uma coisa que a mulher é mais reservada (E6, M, 30a).

O conceito de gênero dos participantes pauta-se na separação e classificação dos sexos e a gênese da diferença existente entre os sexos desvela-se nas explicações dos participantes que prioriza as diferenças biológicas. M1(F) certifica sua concepção fazendo referência ao livro "Homens são de Marte e mulheres são de Vênus"15, que sabemos, apresenta as diferenças comportamentais entre homens e mulheres como sendo decorrentes de diferenças orgânicas e cerebrais. Nos relatos de E1(F) e M5(F), a diferença das características seria naturalizada, ou seja, intrínseca à composição física e anatômica, de caráter biológico do corpo e, portanto, explícitas desde o nascimento. Os relatos exemplificam:

acho que isso já é intrínseco (...) é uma característica [biológica] (...) é muito assim, é muito fidedigno, os homens são assim, é aquela história de os homens são de Vênus e as mulheres são de Marte (M1, F, 35a);

cada um já tem sua função determinada em relação as características físicas (E1, F, 40a).

\footnotetext{
${ }^{15}$ Embora M1(F) tenha dito o nome do livro de modo equivocado, trata-se claramente do livro "Homens são de Marte, Mulheres são de Vênus" com autoria de John Gray, foi publicado no ano de 1996 pela editora Rocco. O autor denomina o livro como um "guia prático para melhor a comunicação e conseguir o que você quer nos relacionamentos". Ao longo do texto é possível observar a ausência de respaldo científico quanto às afirmações e inferências descritas no livro.
} 
a gente vê toda uma diferença do gênero feminino mais voltado, desde a infância, pra questão da procriação. O gênero masculino já não é tão voltado pra esse lado (...) a pessoa se encaixa naquilo que anatomicamente ela nasceu pra ser: ser uma mulher, ou ser um homem (...) algumas coisas a gente vê de bebê, você fala que o bebê é uma menina: o olhar, o jeitinho. Outras coisas você percebe já no primeiro ano de vida (M5, F, 37a).

Embora a participante M5(F) relate acreditar nos fatores educacionais, ela também acredita que esses fatores são superados pela genética quando se trata do desenvolvimento de determinadas características. No seu relato M5(F) descreve uma situação na qual sua paciente, menina e criança, devido uma internação prolongada esteve privada de contatos familiares e mesmo assim desenvolveu determinadas características entendidas como femininas. Cabe destacar que a interação diária com os profissionais da saúde, também pode ser considerada um ambiente de socialização e transmissão de valores culturais. Vejamos o relato:

Existe um ponto de vista assim, educacional. Ah, é porque criou as meninas desse jeito e os meninos daquele jeito. Mas eu acho que tem uma coisa um pouquinho mais funda, um pouco antes, até mesmo genética (...) tenho uma paciente de hemodiálise que tem três anos de idade, e veio de uma família cultural extremamente pobre, que não tem acesso a nada e ela tava há dois anos aqui dentro internada. Então ela não tem um convívio familiar (...) Ela é extremamente feminina. Ela gosta de batom, de esmalte, ela quer pentear os cabelos de um jeito, ela adora as bonecas. E isso é interessante porque é só médico, técnico de enfermagem que tem que estimular. Ela cuida, ela quer dar de mamar, então ela tem toda uma coisa que já vem na própria natureza (M5, M, 37a).

Para os demais participantes a origem das diferenças está na história de socialização, na educação e na cultura. Para E1(F), E5(F) as características de homem "provedor" e "forte" e mulher "submissa" e "dona de casa" é histórica. E2(F), M3(M), M1(F) argumentam que a educação familiar e intergeracional e, também a escolar, estimulam essas diferenças e para E4(M) essa diferenciação é emocional. Para esses 
participantes, portanto, as relações interpessoais sejam elas familiares ou não, ensinam as características dos gêneros, tais como foram citados nos relatos:

é a própria história do homem. Ele sempre foi colocado como o ser mais forte, e a mulher como o sexo mais frágil, o homem foi colocado como o responsável, pai de família, que trabalha e que tem que ter atitude. A mulher já é colocada naquela posição de ser mais mansa, mais humilde e mais dona de casa, cuidar de filhos, essas coisas (E1, F, 40a);

a maioria dos homens ainda são educados dessa forma e isso depois vai sendo refletido (...) são características que foram passadas pelos pais (...) Eu acredito que a maioria seja de berço mesmo (E2, F, 35a);

eu acredito que pela sociedade machista que a gente vive (...) vem de gerações em gerações (M3, M, 36a);

eu acho que é o que é passado pra gente desde que a gente é criança. O que você aprende na escola, na verdade desde que você entra, começa a crescer e se entender por gente é colocado pra você que menino é cor de rosa e que menino é azul. Que menina é delicada e que menino é agressivo, que menino é rude. Então você cresce com essas características (M1, F, 35a);

Acho que vem muito da família mesmo. Um pouco da história, de a mulher ela tem que ser forte, tem que ser corajosa, acho que isso acabou passando um pouco pras mães e elas acabam exigindo das filhas também. E o homem pode ser mais sensível, pode ser emotivo que hoje em dia isso é mais tolerável do que antigamente. Então acho que meio que deixaram isso acontecer (E5, F, 26a);

eu acho que não tem uma explicação genética, não tem uma diferenciação genética, nem tem tanto uma influência genética, o problema é a parte emocional que a gente ta falando (E4, M, 30a).

\subsubsection{Características comportamentais}

Essas concepções se referem às mulheres como sendo comportamentalmente mais flexíveis, sensíveis e meticulosas e independentes que os homens, por que elas pensam mais antes de tomar decisões. Essas características seriam tanto emocionais e subjetivas, ao serem dotadas de sensibilidade, extroversão e flexibilidade, quanto racionais, por serem cautelosas e claras no discurso. 
No caso do feminino, há comportamentos tidos como diferentes, por se tratarem de algo típico de mulheres, como a sensibilidade e a delicadeza, nos relatos de M3(M), e E3(F). Outros relatos de E2(F), E5(F) ressaltam características positivas e vantajosas, como ser mais flexível, confiante e corajosa. E5(F) acredita, inclusive que são os homens quem tem sido dependentes das mulheres. Exemplos de relatos:

a mulher é mais sutil em relação ao homem, é mais flexível em relação ao homem (E2, F, 35a);

ele age mais que mulher, a mulher pensa mais as vezes (E1, F, 40a);

o sexo feminino tem uma sensibilidade maior (M3, M, 36a);

A mulher tem essa coisa de mais sensibilidade, de delicadeza. E eu acho que em relação ao homem é essa coisa mais timidez (E3- F, 31a);

então existem algumas características próprias da feminilidade (...) mulher e delicadeza. Mulher: raciocínio lógico, essa coisa de fazer as coisas raciocinando (...) Então a mulher tem essa coisa mais do raciocínio, mais da delicadeza (...) quando você pensa numa mulher, pensa naquela coisa cor de rosa, naquela menina doce, meiga, racional (M1, F, 35a);

a mulher é mais subjetiva, sensível, né. E o homem é um pouco mais racional, é mais lógico. Quando eu penso na mulher, ela vai mais por intuição, ela planeja uma coisa diferente pra conseguir concretizar, o homem é de uma forma mais seca e objetiva: eu faço isso pra conseguir aquilo lá na frente. De uma forma mais linear. A mulher, não, ela floreia um pouco, coloca um pouco mais de flor aí (M2, F, 37a);

Normalmente elas são mais confiantes, mais corajosas (E5, F, 26a);

o homem tá ficando um pouco dependente da mulher, não a mulher tão dependente do homem (E5, F, 26a).

Por outro lado, a concepção do homem pautou-se no fato deles serem impulsivos, práticos, machistas, inflexíveis, rudes e competitivos, ressaltando que embora sejam práticos no agir, revelam características desvantajosas socialmente, como impulsividade, agressividade, machismo, inflexibilidade, competitividade e inabilidade interpessoal. Além disso, aos homens seria mais difícil a expressão e verbalização de seus sentimentos. Exemplos de relatos: 
talvez a condição dele de agir e pensar que às vezes difere da mulher. A mulher é mais sensível em muitos aspectos em relação ao homem, ela sabe exatamente (E1, F, 40a);

o homem às vezes não sabe se comportar numa situação em que a mulher consiga driblar com mais facilidade (...) A mulher tem mais toque na parte de solucionar algum conflito, quando o cônjuge é mais estourado, né. Nessa parte eu acredito que a mulher é mais centrada. A mulher às vezes pensa mais antes de agir, o homem já é mais seco (...) o homem é mais impulsivo, depois que ele age é que ele vai pensar. (E6, M, 30a);

ele age mais que mulher, a mulher pensa mais às vezes (E1, F, 40a);

o homem ele tem um comportamento bem mais agressivo que a mulher (M4, M, 32a);

O homem pode ser um pouco mais frio às vezes, mas ele consegue ter sentimentos igual a mulher $(\mathrm{E} 4, \mathrm{M}, 30 \mathrm{a})$;

ele quer ser melhor e tem que ser por que ele é o homem, eu acho que é assim, eu sou assim, eu me retraio e acho que as pessoas também são. $\mathrm{O}$ homem não, ele já explode (E2, F, 35a);

O homem é uma coisa mais objetiva, a mulher é aquela coisa mais racional, já vai pensando. O homem é mais objetivo, mais lógico(...) as mulheres são mais racionais e o homens são mais objetivos e isso você percebe desde criança (...) você pensa no homem é aquela coisa mais forte, máscula, brava, agressiva, rude, o azul que é aquela coisa mais forte porque é de criação" (M1, F, 35a);

você entrevista um homem, a resposta dele costuma ser mais dura, ele é mais pontual, mais direto(...) mulheres, têm a tendência de serem um pouco mais...não é prolixa...mas elas respondem as coisas de uma maneira mais completa, são mais abrangentes. Elas desenvolvem o assunto por inteiro (M4, M, 32a).

A participante M2 atribui ao masculino e ao feminino, características que são baseadas em atitudes parentais que remetem aos atributos comportamentais parecidos aos descritos nos relatos anteriores. A mãe seria delicada, carinhosa, o pai por sua vez seria forte, direto, objetivo:

O feminino me lembra mãe. O masculino lembra pai: Aconchego, proteção. $\mathrm{O}$ feminino me lembra o gênero da origem, que se encarrega dos filhos (...) a característica do pai é aquele que vai dar a sementinha. Que serve pra proteger a família, que serve pra proteger de uma forma diferente da mãe. A mãe tem o aconchego, o pai tem uma proteção diferente. A mãe protege com um carinho diferente do pai, né? Mãe é sempre delicada, sempre carinhosa. Daí vêm o meu pai que é grandão e tal, né. Que não tem aquele carinho, mas que quando você vem te 
aconchega, te orienta. Fala: "você tá certo", "você tá errado" (M2, F, 37a).

Nas falas de E5(F) e M5(F) há o destaque sobre determinadas características comportamentais já notadas nas crianças, e que nos adultos esse comportamento pode mudar dando lugar às atitudes valorizadas para o homem, vejamos o relato:

a criança do sexo masculino normalmente é a que tem mais medo que as de sexo feminino. Eles são, não sei se mais desconfiados, mais amedrontados (...) Em adultos a gente ainda percebe aquela fachada de super homem, de ter que agüentar determinadas situações por ser homem (E5, F, 26a).

A maneira como as meninas olham a boneca, pegam a boneca é diferente. E os meninos, não (...) a menina tem o jeito mais delicado. Então a menina quando pega o carro pra brincar, ela brinca de maneira mais delicada. Ela anda com o carro, coloca o bebê no carro, cuida do carro. O menino quando pega o carro, ele quer brincar, quer correr, quer ver o quanto que ele derruba (M5, F, 37a).

Segundo M2(F) a adolescência seria o marco para que as diferenças nos comportamentos de homens e mulheres sejam evidentes:

O adolescente já começa a mudar um pouquinho, principalmente no que é relacionado à sexualidade. E acontece muito mais mudanças em mulheres do que em homens. Acho que é aí que começa a ter uma maior diferença em termos de sexo (...) homens mais agitados que meninas e meninas mais desatentas do que meninos. Fica muito mais no mundo da lua, fica pensando (M2, F, 37a).

Seja na infância ou na adolescência, há uma percepção de que os comportamentos tidos como femininos e masculinos mudam nas pessoas com o tempo e a socialização.

\subsubsection{Características sociais}

Os padrões sociais foram lembrados como determinantes nas diferenças de homens e mulheres quando os participantes se referiram ao fato de haver repressão social que direciona e impõe como as pessoas devem agir em função do gênero a que pertencem, por exemplo, o modo de se vestir e se comportar das mulheres. Enquanto a sociedade parece direcionar padrões de comportamento e vestimenta às mulheres, o mesmo 
aconteceria aos homens, mas esta repressão estaria direcionada aos aspectos emocionais.

Homens seriam mais reprimidos quanto à expressão de emoções e a exposição de fragilidade física ou emocional. Isso pode sugerir a hipótese de que os padrões hegemônicos de gênero na atual sociedade priorizam a integridade moral das mulheres que devem ser sedutoras, mas não vulgares e a heterossexualidade masculina relacionada aqui com masculinidade e machismo. Exemplos de relatos:

ele não pode chorar, não pode extravasar determinados sentimentos (E2, F, 35a);

eu ainda vejo coisas assim, que mulher não pode sair de casa, tem que usar uma roupa adequada e não a que ela quer usar. Em muitas culturas existe isso. Em muitas religiões mulher não pode se portar, não pode ter uma atividade, tem que ser do homem (E1, F, 40a);

Acho que a sociedade ainda exige um pouco isso. Que a mulher seja delicada, mesmo que seja durona, mas tem que ter essa delicadeza, a parte feminina da mulher. E o menino tem que ser homem, tem que ser macho, não pode chorar, tem que ser forte (...) Tanto que a gente percebe em meninos que sejam mais sensíveis, às vezes até sofrem preconceito, alguma coisa assim, só porque ta expressando o sentimento (...) E as meninas também, de serem mais duronas, serem mais firmes, as pessoas interpretarem como não sendo femininas (E5, F, 26a).

Segundo E3, a sociedade também restringiria às mulheres certas oportunidades de vivenciar experiências diferenciadas ao longo da vida e para E4 os valores que atribuem ao homem o papel de provedor da prole ainda está em voga mesmo que a mulher compartilhe a função de prover a família:

A mulher ela é assim mais reprimida, eu acho que a mulher é sempre mais reprimida que o homem. A mulher não tem esse instinto de aventura, de liberdade que o homem tem. Pra ela tudo é mais dificultado. É uma coisa da sociedade, né, pra mulher é tudo mais complicado. Eu acho que o homem tem bem mais essa coisa do instinto, da aventura (E3, F, 31a);

(o homem) é o provedor da família ou o responsável por uma família, também pelas decisões que devem ser tomadas pelo homem. Ele seria o responsável, entre aspas, né, sobre as outras pessoas que dependeriam dele. Hoje em dia a mulher já ta tomando essa característica de provedor da família (E4, M, 30a). 


\subsubsection{Características físicas}

Uma característica atribuída à mulher como vantajosa referiu-se a questão biológica na maternidade: mulheres podem ser mães. Nenhuma característica similar ou correspondente foi atribuída ao masculino, ressaltando, por exemplo, a paternidade e a capacidade de fecundação. Exemplos de relatos:

o que pode fazer mesmo a diferença é a maternidade para a mulher (E1, F, 40a);

O que a gente vê no feminino é toda uma habilidade voltada pra procriação, a reprodução. Então tem o cuidado, todo um modo de ser voltado pra procriação (M5, F, 37a)

O feminino (...) eu vejo que é caracterizado pela feminilidade como o próprio nome diz, pela característica física também (E2, F, 35a).

O que caracteriza o feminino acho que a capacidade de gerar filhos e de amamentar, acho que isso diferencia bastante e caracteriza bastante (...) $\mathrm{O}$ masculino tem essa não capacidade de gerar (E4, M, 30a)

De acordo com E5(F) os homens estariam mais predispostos a acometimentos severos em saúde, justamente por um hábito comportamental típico: não procurarem os serviços de saúde nas primeiras manifestações dos sintomas:

os homens são mais predispostos. Acho que por não ter esse cuidado médico, por deixarem pra muito tarde: 'ah, na terceira idade eu vou', 'quando eu ficar doente eu procuro um médico'. Então eu acho que isso acaba prejudicando muito. Por que muitas vezes quando chegam ao médico já estão com alguma coisa avançada, com alguma doença que já poderia ter sido descoberta, ou ter iniciado algum tratamento antes, talvez se ele fosse por prevenção, ou só pra se cuidar mesmo ele já teria resolvido, né. Mas eu acho que pelo número de homens, mesmo, é maior predisposto a doenças (E5, F, 26a).

Para a participante E1(F) homens e mulheres não apresentam diferenças na predisposição a doenças nem na resposta ao tratamento, mas os acometimentos podem estar relacionados aos hábitos de vida que cada indivíduo possui:

mas se a gente for pensar nos dados estatísticos a gente vai ver que praticamente é a mesma coisa (...) pensando fisicamente não justifica, é aquilo que a gente faz que pode trazer as consequiências e não aquilo que a gente é (E1, F, 40a). 
Segundo M3 e M1, algumas doenças poderiam acometer mais a um ou a outro sexo dependendo da doença:

Tem doenças que atingem mais um sexo ou outro (M3, M, 36a);

Tem estudos que mostram isso que dependendo da patologia tem mulheres que tem mais predisposição e dependendo da patologia é o homem que tem mais predisposição. Então depende da doença vai ter mais predisposição pra homem ou pra mulher, mas depende da patologia (M1, F, 35a).

Segundo E3 e E4 as mulheres estariam mais vulneráveis a doenças devido a um desgaste físico maior ou devido sua composição física. E4 argumenta que a interação entre o corpo feminino, os remédios comumente utilizados por algumas mulheres e determinados hábitos de vida resultariam em vulnerabilidade:

Ela é mais vulnerável assim, em termos de imunidade, ela acaba se tornando uma pessoa mais vulnerável: imunidade, psicológico, hormonal. Tem muita alteração hormonal na mulher (E6, M, 30a);

A mulher está mais predisposta (a doenças) (...) eu acho que até mesmo pelo desgaste físico dela, que é maior, entendeu? E assim, tem os anticoncepcionais, tudo isso (E3, F, 31a);

As doenças acometem mais mulheres, algumas que acometem as mulheres não aparecem nada no homem apesar de ele ser portador, algumas doenças ginecológicas (...) a mulher, ela é mais predisposta, principalmente agora com o anticoncepcional, mulher fumando, bebidas alcoólicas, ela tem uma carga maior de exposição a problema vascular, cardíaco e oncológico (E4, M, 30a).

\subsection{Gênero e Comportamentos de cuidados com a saúde/doença}

Nesta categoria foram agrupados os dados referentes aos comportamentos de cuidados com a saúde que se relacionam à conduta de homens e mulheres quanto à prevenção ou ao tratamento de doenças.

\subsubsection{Comportamentos de cuidados com a saúde e doença em função do} gênero

Para os participantes as mulheres cuidam mais da saúde, se previnem mais, são mais preocupadas com a saúde e aderem ao tratamento. Segundo alguns dos participantes, 
embora tenham medo e receio, as mulheres procuram mais os serviços de saúde, são mais dedicadas e interessadas no diagnóstico e no tratamento e, ainda, aceitam mais os exames que possam ser invasivos, pois estão acostumadas com isto e, principalmente, tem mais atitudes preventivas. Esses dados aparecem nos relatos elucidados a seguir:

a mulher é um pouco mais medrosa em relação ao homem (E1, F, 40a);

Mulher qualquer coisinha vai ao médico, né. Uma dor de cabeça, se ta tensa. Mulher se queixa mais, se preocupa mais (M2, F, 37a);

a mulher é mais preocupada, mais dedicada, ela busca informação, ela não tem assim, alguns tabus em relação, pelo fato de o exame ficar exposto, de ficar exposta. A mulher ela tem essa consciência da importância da saúde dela antes de tudo (...) A mulher geralmente ela sabe que ela vai ta exposta aí, mas que esse bem é fundamental pra ela, e essa exposição é fundamental (E6, M, 30a);

A mulher principalmente na prevenção ela previne muito mais do que o homem (E2, F, 35a);

a mulher ela tem essa coisa de perceber essas coisas menores ela está mais atenta ao detalhes entendeu. Com isso ela acaba percebendo os primeiros sintomas, ela vai acaba indo atrás no começo, ela vai atrás, ela se preocupa mais, ela tem esse tempo (M1, F, 35a);

a mulher aceita as condições de tratamento. A mulher se ela tem uma orientação médica, ela vai seguir (...) A mulher, embora tenha isso também, ela é um pouco mais receptiva nisso (...) Ela aceita melhor essa condição de ter que se sentir manipulada, de ter que tomar medicação (E3, F, 31a);

Preventivamente ela se preocupa mais, faz mais exames preventivos do que os homens (...) a mulher adere melhor ao tratamento. Ela consegue assimilar melhor a doença e consegue administrar melhor esse tratamento também (E4, M, 30a);

A mulher, ela tem a consciência da prevenção (...) então a mulher ela segue muito mais à risca a prevenção do que o homem (E6, M, 30a);

quem adere melhor ao tratamento, à medicação, às condutas, vai ser a mulher(...) As mulheres se cuidam mais, elas ficam mais atentas às prescrições, às sensações. $\mathrm{O}$ masculino não (...) E na grande maioria, as mulheres, nem que for pra fazer exame de prevenção de câncer, já foi ao médico uma vez na vida na adolescência. Se não foi na infância, foi na adolescência (M5, F, 37a).

Os participantes também acreditam que os homens possuem mais dificuldade/preconceito para se submeter aos procedimentos manipulativos ou invasivos, 
possuem medo das conseqüências dos problemas de saúde e só procuram os serviços médicos quando já existe um comprometimento significativo de sua saúde. Também demonstram medo e receio, mas explicitam raiva e revolta e, alguns participantes atribuem esses comportamentos ao "machismo" e às características típicas do masculino.

Os relatos a seguir exemplificam essas concepções:

é um pouco mais preconceituoso, não lida bem com o ficar doente, (...)nós homens vamos menos atrás da saúde do que as mulheres (M3, M, $36 a)$;

O homem é mais reservado, um pouco mais machista e acaba não colaborando pra realização de alguns exames específicos (E6, M, 30a);

O homem não, só quando ele está no limite é que ele vai procurar ajuda. A prevenção mesmo eles não realizam. (...) Ele é machão e é muito mais difícil dele aceitar a prevenção (E2, F, 35a) O homem geralmente procura quando ele ta numa fase em que ele não pode intervir mais na saúde dele. Porque, se ele puder intervir, ele vai intervir até onde dá (...) eles têm um tabu com o exame da próstata, que é o que tem mais estigma em relação ao sexo masculino. A masculinidade do homem é coisa da próstata (E6, M, 30a);

o homem, pela própria característica dele, pelo próprio tipo dele. Por essa coisa de ser o forte, o másculo, o protetor da casa, ele não tem tempo de se preocupar com coisas pequenas. E a saúde é tida como uma coisa pequena. O homem só vai procurar o médico quando ele está com alguma doença (M1, F, 35a);

O homem não. Toda vez que o homem fica doente ele sente um pouco de revolta. Revolta por estar doente, revolta por se sentir invadido, revolta por ter que ser manipulado (E3, F, 31a);

O homem acaba ficando meio arredio, não quer tratar, tem medo, medo das conseqüências que pode dar, medo de ficar impotente, ou alguma coisa de perder a masculinidade dele (E4, M, 30a);

O homem só vai tomar consciência disso quando ele já ta afetado e às vezes são seqüelas irreversíveis. Aí ele toma consciência do tratamento, mas ao contrário, até que se chega nessa fase de seqüela irreversível, ele não segue à risca $(\mathrm{E} 6, \mathrm{M}, 30 \mathrm{a})$;

Destaca-se nos relatos de E2(F) e E4(M), o fato de que os cuidados diferentes com a saúde se fundamentam na educação sexista que meninos e meninas recebem ao longo de sua socialização, vejamos o relato: 
A mulher principalmente na prevenção ela previne muito mais do que o homem. Lógico, é uma coisa desde menina, a mulher na maioria das famílias ela já é criada para ter determinados cuidados com ela mesma (E2, F, 35a).

É até cultural, tem uma cultura de que a mulher tem que fazer o Papa Nicolau, fazer acompanhamento ginecológico, o parto, ter filho, essas coisas (...) ela até culturalmente, foi desenvolvida, pra ela se preocupar mais com a saúde do que o homem. O homem tem aquele estigma de medo, melhorou muito no homem essa parte de fazer a prevenção, mas ainda é a mulher que procura mais a prevenção do que o homem (E4, M, 30a)

Outra noção sobre a origem da diferença nos cuidados com a saúde está pautada na demanda fisiológica característica do corpo feminino, ginecológico e posto para a maternidade, o que por sua vez torna os cuidados com o corpo uma rotina. Mais uma vez é o anatômico e o biológico que impulsiona, na percepção dos participantes, comportamentos diferentes de cuidados com a saúde que acabam sendo explicitados socialmente. Exemplo:

a mulher é mais preocupada pelo fato de que ela é, ela tem algumas características fisiológicas que às vezes requer mais cuidado que o homem. Até falando pelo lado mesmo da maternidade. A mulher obrigatoriamente tem que fazer exames anuais e semestrais, ela tem essa obrigação (E1, F, 40a);

Eu acho que mulher tem mais acesso, até porque como ela tem o sangramento mensal, ela é obrigada a ir ao ginecologista com mais freqüência, ela é obrigada ter um médico no trabalho de parto. Então ela se habitua a procurar um médico (...) A mulher não, uma gravidez ou alguma outra coisa, ela vai ao médico. É uma rotina pra ela, entendeu (...) os partos, né, que ela tem que acompanhar. Então acaba virando rotina. Acaba ela levando as crianças ao médico, a área da saúde é dela (E3, F, 31a);

culturalmente foi desenvolvida essa preocupação maior com a mulher. Até porque é maior a quantidade de doença, ela acabou sendo mais cuidadosa (E4, M, 30a).

Há também aqueles participantes que flexibilizam a questão, sem direcionar aos fatores orgânicos ou aos psicossociais e, apontam outras condições, além do gênero, que podem determinar os comportamentos de cuidar da saúde, como a história pessoal, as 
relações na atividade do trabalho que realizam, podendo variar de acordo com a área da saúde e, ainda, condições sociais e econômicas diversas. Vejamos o relato:

depende muito do ramo de atuação das pessoas, não é. Acho difícil dividir assim, eu acho que igual [homem ou mulher]. Depende muito dos afazeres de cada um, dos hábitos de vida de cada um. Acho que não tem diferença, não. Tem homem que se cuida, tem mulher que se cuida, tem homem que não tá nem aí, tem mulher que não tá nem aí também (M4, M, 32a);

O cuidado é mais relacionado ao nível sócio econômico e cultural do que ao gênero (...) A gente nota que pacientes com as condições muito precárias, não conseguem lidar com algumas situações tão bem quanto aqueles que têm uma situação melhor, um nível de escolaridade melhor (M2, F, 37a);

Eu acredito também que o social da pessoa esteja envolvido, porque a pessoa, elas têm consciência da importância de cuidar da saúde, agora, vai um pouco de cada um de cuidar ou não. É complicado, assim, a gente determinar se é o fator sexo, o fator idade, o fator socioeconômico, porque varia de pessoa pra pessoa independendo de qual posição social ela ocupe (E6, M, 30a).

\subsubsection{Compreensão de como e por que mulheres e homens cuidam da saúde e}

\section{lidam com a doença e com o tratamento}

Para os participantes M1(F), E2(F), E1(F) e E3(F) as mulheres se preocupam mais com a saúde, possuem mais comprometimento com os cuidados de si e demonstram fragilidade, sem dificuldade:

ela está tendo a dor por que ela se queimou, mas que se ela fizer vai se recuperar, que precisa tomar banho. Ela lida com aquilo melhor e o homem não ele sentiu dor e ele não quer cooperar, não quer fazer (M1, F, 35a);

As mulheres são mais envolvidas, quando a gente chama pra conversar, para orientar em relação a um diagnóstico que é desfavorável para a paciente, elas conseguem assimilar melhor do que os homens (E2, F, $35 a)$;

a mulher pode se queixar por muita dor de cabeça, mas já tem aquela idéia de procurar um médico. Não que ela seja hipocondríaca, mas já fica preocupada com aquilo pra ir procurar um médico e resolver o problema (...) acho que a mulher está mais aberta, não porque ela queira, mas pela própria condição mesmo que ela fica mais aberta a receber essas informações e até mesmo procurar ajuda ou outras informações mais certas (E1, F, 40a). 
Na compreensão dos entrevistados, os homens se consideram resistentes, negam a possibilidade de que possam adoecer. Os homens são preconceituosos quanto à prevenção e arredios no tratamento de doenças, possuem vergonha de procurar ajuda e se sentem inferiorizados por estarem adoecidos ou dependentes. Nesse sentido, para eles, os homens não fazem prevenção e não seguem o tratamento, apenas procuram ajuda quando a situação de saúde está bastante comprometida. Com maior frequiência somente os homens mais velhos se engajam nos cuidados com a saúde. Exemplos:

ele fica um pouco mais assim: "não vai!" (...) por que ele considera: 'eu não vou ficar doente, eu to bem, e dependendo do médico ele já não vai por vergonha de ir, medo de algum tipo de exame que ele possa ser exposto, ou vergonha mesmo (E1, F, 4a);

homem é durão, homem não fica doente "magina, você vai no médico pra que? Tá tudo bem, você ta forte aî" (E5, F, 26a);

quando um paciente interna, ou que a gente vê que eles estão debilitados, eles têm aquela coisa de pudor, principalmente a parte do pudor, né. Principalmente os homens de 40 anos que têm que fazer o exame da próstata, né? (...) A mulher já não. Ela sabe que ela vai ficar exposta, mas aquilo lá é pro bem dela. $\mathrm{O}$ homem até sabe, mas ele não aceita. (...) $\mathrm{Eu}$ acredito que seja um fator, o machismo, principalmente. Que ele vai achar que ele vai ser menos homem que os outros homens da rua, porque o médico fez o exame nele, ou que alguém da saúde, outro homem tocou nele. Acredito que seja essa parte do machismo, porque eles sabem da importância (E6, M, 30a);

a mulher assume mais, ela leva com muito mais afinco. $\mathrm{O}$ homem toma remédio e começou a sarar, ele abandona (M1, F, 35a);

Acho que os homens acabam meio que relaxando: "ah, tô bom, não vou tomar mais (E5, F, 26a);

Eu acho que as mulheres se preocupam mais do que os homens. Acho que os homens deixam pra muito tarde, lá na terceira idade, quando começam a aparecer sintomas. Antes de aparecer sintomas eles não se preocupam (E5, F, 26a);

O homem já é mais difícil, tanto que hoje o câncer de próstata mata muito mais que o câncer de útero. E porque a mulher cuida muito mais do que o homem (...) o homem não, só quando ele está no limite é que ele vai procurar ajuda. A prevenção mesmo eles não realizam, ele tem mais aversão ao resultado do exame (...) A grande maioria vem já querendo não saber, já querendo ir embora; quando eles vem muito avançado, eles acabam desistindo (E2, F, 35a);

Acho que o homem ainda tem essa vergonha de se ver numa condição inferior (...) ele se sente inferiorizado por estar doente", "com a idade, 
tende a se igualar, porque aí o homem aceita melhor seguir as orientações (M3, M, 36a);

A grande maioria vem já querendo não saber, já querendo ir embora; quando eles vêm muito avançado, eles acabam desistindo (E2, F, 35a);

A mulher, eu acho que ela da uma continuidade melhor ao tratamento. Então a doença na mulher, ela controla melhor, ela tem menos variações. O homem já não, ele quando ele fica bom, ele pára de tomar o remédio, daí a doença piora e volta novamente onde tava (E4, M, 30a);

homem faz tudo errado, não toma remédios direito. O homem parece que fica negando, fica "não, eu não preciso fazer isso, eu faço o que quero" (M3, M, 36a);

homem muitas vezes ele não volta, tem alguns pacientes que você faz o acompanhamento", "ele não volta pra ter o diagnóstico e você percebe que ele desistiu no meio do caminho (E2, F, 35a);

o homem só vai quando já é uma coisa grande, quando ele precisa realmente (...) para ele é mais traumatizante, depender dos outros é traumatizante, tudo é mais traumatizante do que pra mulher (M1, F, $35 a)$;

o homem suporta mal o ficar internado. Mas eu sempre tenho a sensação de que os homens lidam de forma pior com isso. Existem outros casos de paciente que fugiu, acho que todos praticamente eram homens (M3, M, 36a).

De acordo com E5(F) o objetivo estético contribuiria para que mulheres se aproximassem dos serviços de saúde:

há uma grande tendência a ir pela parte estética que eu acho que ta crescendo demais, mas acho que vem vindo junto a parte estética versus saúde. (...) Eu acho que a estética acabou levando muita mulher pra essa parte e agora não é mais estética é ser saudável e ser bonita, então acho que isso ajudou muito nessa parte (E5, F, 26a).

Segundo os entrevistados, as mulheres são mais apreensivas com as doenças, pois tem mais medo de morrer e não poder cuidar dos filhos. Os homens, por sua vez, se preocupam com o trabalho, evitam os contatos com os profissionais da saúde e com o diagnóstico e não possuem tempo para buscar condições de saúde. Os excertos abaixo ilustram esse ponto de vista: 
eu acredito que a mulher é um pouco mais medrosa em relação ao homem, tipo: 'e se acontecer alguma coisa comigo, se eu ficar doente, se eu morrer quem vai cuidar dos filhos, quem vai cuidar da casa'(...) tem a questão do tempo, ele fica preocupado com o trabalho e de não querer deixar o trabalho pra procurar condições de saúde, ir ao médico (...) homem é muito mais prático, está sempre com hora marcada pra tudo no sentido geral da coisa (E1, F, 40a);

às vezes pros filhos, ter uma boa saúde pra cuidar dos filhos, preocupada com isso. Eu acho que a própria luta das mulheres de serem independentes, então, serem independentes nessa parte também de procurar, de se tratar, de estar bem, independente se tem um marido, se não tem, se teve uma ajuda ou não teve (E5, F, 26a);

os homens são mais medrosos mesmo, mais ansiosos, querem que a fila acabe logo, querem ir embora logo (E5, F, 26a);

Acho que as mulheres têm um pouco mais de medo. Vão tomar certinho pra garantir que aquilo não aconteça de novo (E5, F, 26a);

a mulher assume mais, ela tem um comprometimento mais familiar em se tratar dizem muito coisas do tipo 'eu preciso me cuidar pra cuidar do meu marido, pra cuidar dos meus filhos (M4, M, 32a).

[O homem] fica sem condição, sem estrutura para poder trabalhar (E1, F, 40a);

a mulher ela vem e vai em todo o acompanhamento e faz o tratamento completo; ela fica tão apavorada que aí ela quer tratar o mais rápido possível na grande maioria (E2, F, 35a).

A paciente tem preocupação com os filhos, com limpar a casa (...) já a preocupação do homem é mais financeira (...) quanto tempo sem trabalhar, essas coisas (M4, M, 32a).

As participantes E1(F), M5(F) e E4(F) argumentam que mulheres aprendem a cuidar de si e a cuidar do outro e assumem mais os tratamentos em saúde, em sentido oposto os homens apresentam dificuldades para lidar com diagnóstico e para seguir corretamente o tratamento:

a mulher com um lado mais cuidadora, quando tem alguém doente, geralmente é uma mulher que está do lado cuidando", "Se a mulher fica doente, com certeza é outra mulher que vai ter que deixar algumas atividades para cuidar dessa que está doente (E1, F, 40a);

na vida adulta, com certeza, a mulher. Ela vai mais ao médico e assim, dos acompanhantes das crianças, $99 \%$ é mulher (...) não são os homens que vêm trazer seus filhos, quando vem é pra trazer até aqui, não na consulta. São pouquíssimos os pais que ficam com os filhos nas consultas. E quando ás vezes vem, ele não tava informado do que 
acontecia com seu filho. Não sabe se ta doendo, se teve febre. (...) a mãe que cuida da saúde também, a mãe que alimenta, a mãe que cuida, a mãe que vai até o fim com aquela criança (M5, F, 37a);

As mulheres sempre ficam com as responsabilidades maiores. Em caso de deficiente, se a pessoa tem um filho... a mulher é cuidado integral. $\mathrm{O}$ marido até participa, mas o cuidado integral fica com ela. Sempre ela. (...) em sete anos de trabalho eu posso citar pra você nos dedos de uma mão só quantos pais eu vi por aqui (...) Acaba ela levando as crianças ao médico, a área da saúde é dela (E3, F, 31a);

Em contrapartida de acordo com M2(F), os pais são participativos nos cuidados da saúde de seus filhos e em algumas situações possuem mais informações sobre os filhos do que as mães:

Às vezes a gente fica com uma impressão errada de que às vezes o pai não é tão participativo. E não é essa a impressão que eu tenho. Uma impressão, dentro da minha vivência particular, uma boa parcela dos meus pacientes vem acompanhados do pai, não da mãe. E muitas vezes o pai sabe mais dados do que a mãe, dados próprios do nascimento. A maioria acha que pai não sabe de peso, de altura, e quanto tempo, mas lembra, lembra sim. É lógico, tem mãe que não sabe nem o dia que o filho nasceu, nem o nome do filho. E tem pai que sabe bastante (M2, F, 37a).

Para M1(F), o fato de a mulher ser mais clara e se expor mais nas interações comunicativas, o que a levaria a ter mais necessidade de ser compreendida e também de compreender os acontecimentos ao seu redor. O homem, por outro lado, seria mais objetivo e prático e percebe o mundo de modo mais direto; isso o levaria a não ter a necessidade de falar sobre suas dificuldades. Vejamos o relato:

ela acaba se expondo mais porque ela tem uma dificuldade muito grande de entender o homem (risos) e ela tem uma necessidade de que os outros ajudem ela a entender, não só o homem, mas entender o homem, entender a vida (...) então é uma dificuldade que ela tem de entender os próprios sentimentos, as relações com as outras pessoas e aí ela se acaba se expondo nessa tentativa de se entender e entender os outros (...) eu acho que a mulher tem essa dificuldade de entender, essa dificuldade de raciocinar, de lidar com os sentimentos (M1, F,35a).

De acordo com os entrevistados M4(M), M3(M) e E1(F) as mulheres por assumirem mais o tratamento estão em maior número nas instituições de saúde preventiva 
primária e secundária e homens e mulheres hospitalizados possuem comportamentos diferentes. E para E5(F), por assumirem menos os cuidados com a saúde os homens estão em maior quantidade nas unidades de internação:

a paciente internada e o homem internado são muito diferentes (M4, M, 32a);

acho que elas se sentem à vontade pra chorar dificilmente uma mulher foge do tratamento (M3, M, 36a);

uma comparação do número de pacientes que nós temos aqui, o número maior é de mulheres, pode ter certeza. Se for no ambulatório pra gente saber os quais números a mais que eu tenho em relação as mulheres que está procurando um tratamento, procurando uma solução para o problema de saúde (E1, F, 40a).

é visível a diferença entre internação masculina e feminina, é muito mais homem do que mulher (E5, F, 26a)

Segundo os profissionais em geral os homens se queixam mais quando estão com dores ou doentes e necessitam sempre de acompanhantes durante as internações. Curiosamente os padrões do masculino relacionados à força, racionalidade e objetividade não se manifestaram no masculino quando o homem aparece diante do adoecimento. Os exemplos a seguir abordam essa percepção:

a gente vê é que esse dengo do homem é por ele se considerar aquela pessoa forte e que agora está em uma situação desprivilegiada, estar dependente de alguém. Então tudo que você faz com ele dói, tudo que você fala ainda (E1, F, 40a);

Porque homem, uma agulhinha pra ele se torna uma faca. Então ele é mais queixoso assim, em termos de procedimentos invasivos (E6, M, 30a);

O homem, ele acha que é uma fortaleza. Só que a gente vê com o passar do tempo, com a experiência que eu tenho no hospital, que o homem é muito mais frágil que a mulher (...) ele acha que se começar a se queixar, ele acha que vai começar a se igualar com a mulher e eu acho que é isso que ele não quer e quando eles vêm pro hospital debilitados, doentes, a gente vê que eles são muito mais frágeis que as mulheres, são muito mais vulneráveis (E6, M, 30a);

Ele choraminga mais; cara que era o homem fortaleza antes de começar a tratar, começou a tratar pronto, tem uma dor ali, tem não sei o que (M4, M, 32a); 
dificilmente ele fica sozinho na recuperação cirúrgica; Geralmente o homem acaba solicitando, só que em contra partida por ele ser mais durão, mas ele acaba solicitando por ser tudo tão difícil pra ele (E2, F, $35 a)$.

Agora a nível de hospital o homem é mais dengoso (...) por que muitas vezes o dengo dele não é tão valorizado como a queixa da mulher. E o homem fica com essa coisa de 'estou com isso, estou com aquilo' para chamar sua atenção e ter alguém por perto a gente vai, conversa, dá uma atenção (E1, F, 40a).

se a esposa não for lá, não pegar no pé, se os filhos não ficarem no pé, não sei se é uma dependência, se é uma carência, de alguém tem que levar o pai, tem que acompanhar o marido. Acho que às vezes eles precisam dessa dependência aí, da mulher (E5, F, 26a)

Nos relatos de E1(F), M1(F) e E2(F) as mulheres são vistas como possuidoras de mais facilidade para lidar com dores e mais independentes:

A mulher não é tanto dodoizinho assim no sentido dengoso de cuidar (...) a mulher chama muito mais quando ela está realmente com dor, quando está precisando de alguém (E1, F, 40a);

com um homem eu jamais lido a cirurgia dele sem ir a esposa junto, por que eu sei que o trabalho que ele vai dar pra esposa vai ser imenso (M1, F, 35a);

mas ela não depende tanto de um acompanhante, mas em determinados procedimentos (...) a mulher por ela ser mais flexível, ela aceita melhor a situação, A mulher ela tende a enfrentar melhor esse problema, esse tratamento (E2, F, 35a);

O entrevistado E6(M) argumenta que a mulher solicita mais a presença de

familiares, pois se sente mais frágil quando acometida por alguma moléstia. E M5(F)

entende que as mulheres ficam mais deprimidas quando doentes e se queixa mais que os

homens:

geralmente eles solicitam menos familiares pra acompanhamento do que a mulher. A mulher solicita mais. A mulher fica meio chorosa, mais frágil (E6, M, 30a);

Mulher tem esse comportamento hormonal, mas eu acho que é cultural. A mulher adulta se queixa mais, deprime quando adoece, mais do que o homem (...) seus hormônios, então, vai definir mesmo. Agora, eu acho que é de certa forma cultural (...) A mulher ao mesmo tempo em que adere melhor, ela tem um emocional muito mais deprimido. Então a mulher quando adoece, ela deprime mais (...) Mulheres choram mais até 
por natureza também (...) O homem, a maioria dos homens, não tem quase nenhuma queixa. A mulher queixa mais (M5, F, 37a).

De acordo com os entrevistados as mulheres são mais claras e fidedignas ao descrever seus problemas de saúde e também questionam mais os profissionais para compreender sua situação de saúde. Em direção oposta os homens evitam falar de seus problemas e não conseguem descrever com clareza os sintomas. Vejamos os relatos:

A mulher ela já mantém, é mais a frente, é questionadora (...) a mulher ela quer saber mais e você tem que dar maiores explicações e não convence com a primeira coisa que você falou (E2, F, 35a);

ela normalmente parece ter uma percepção melhor das coisas que ela tem, então ela fala com mais fidedignidade de uma dor que começou em tal período (...) $\mathrm{O}$ homem normalmente chega falando que ele é realmente assintomático (...) A mulher, normalmente, tem uma abordagem muito mais completa. Ela responde coisas sistematicamente; com homem você pergunta: 'tem dor de barriga?', 'tenho de vez em quando', daí você puxa o resto, com mulher não, é mais fácil (M4, M, 32a).

\subsection{Atuacão cotidiana no atendimento a homens e a mulheres}

Para os entrevistados/as, sejam esses homens ou mulheres, há a percepção de que a relação profissional com homens apresenta maior dificuldade devido às características do homem ao lidar com a saúde, bem como sua dificuldade para ser claro ao falar dos sintomas. Exemplos:

homem é muito mais fechado ele tem muito medo de se expor e do que essa exposição vai causar (...) o homem dá mais de trabalho no sentido que ele é mais chorão, o limiar de dor dele é mais baixo, ele sente mais, sofre mais (M1, F, 35a);

o homem acaba escondendo, a gente tem que ficar tirando com saca rolha(...) Homem fica com a cara meio fechada, você não sabe se tá entendendo, se não tá entendendo, se tá negando a doença (M3, M, 36a);

o homem é mais arredio, dependendo do procedimento que você vai fazer. Ele acha que não é certo, que não precisava daquilo, entendeu? A mulher já não, já aceita melhor certas coisas (...) quando o paciente chega mais arredio, você acaba tendo que conversar mais, explicar, você tem que convencer da necessidade daquilo, entendeu? Daí fica um pouco mais difícil (...) Com homem você tem um tempo maior convencendo 
(...) mas você tem que adaptar mais pra realizar o mesmo procedimento que numa pessoa que aceita melhor seria mais fácil (E4, M, 30a);

Ele não toma muita atenção, ele quer que você acabe logo. A mulher já não, ela é bem atenta em relação ao que você ta dizendo, ela é inteligente, até porque ela não ta muito preocupada, ela tá menos preocupada em relação ao fato de ser invadida (E3, F, 31a);

O homem ele é mais difícil, pelo meu ponto de vista homem é uma pessoa mais difícil de lidar. Às vezes você está explicando para o homem e ele "tá bom", e você olha no olho dele e ele não está aceitando aquilo que você está falando (E2, F, 35a).

Por outro lado, as formas como as pacientes mulheres lidam com a saúde e também suas habilidades para falarem sobre si mesmas e sobre os sintomas, são percebidas pelos entrevistados como um facilitador da interação. Os atributos da feminilidade aparecem como um facilitador no atendimento do profissional de saúde, no processo de diagnóstico e de tratamento de doenças. Vejamos os relatos:

é muito mais fácil você descobrir isso [a história da patologia] de uma mulher do que do homem, é muito mais rápido, muito mais fácil (M1, F, $35 a)$;

acabo preferindo lidar com pacientes do sexo feminino. Com mulher elas seguem melhor (...) e a gente tem um sucesso maior, é gratificante pra gente enquanto profissional (M3, M, 36a);

eu não tenho dificuldade, porque eu me comunico super bem com todo mundo, independente se é homem ou se é mulher (...) A mulher é muito mais colaborativa, daí é mais fácil trabalhar com mulher do que com homem (...) Com o homem tem que a ser um pouco mais direto. Com a mulher você chega e ainda consegue fazer algumas brincadeiras (E6, M, 30a);

acredito que nessa comunidade dos profissionais da saúde, eles valorizam bem mais as queixas da mulher, ela prefere descansar e fazer a reclamação realmente no momento que ela tem dor (E1, F, 40a);

mais fácil de você lidar com a situação, você orientar a mulher do que o homem (...) a mulher por ela ser mais flexível, ela aceita melhor a situação, a mulher ela tende a enfrentar melhor esse problema, esse tratamento (E2, F, 35a);

A mulher, normalmente, tem uma abordagem muito mais completa. Ela responde coisas sistematicamente; com homem você pergunta: "tem dor de barriga?", "tenho...de vez em quando". Daí você puxa o resto, com mulher não, é mais fácil (M4, M, 32a); 
ela chega e conta a vida dela, ela foi pra cuidar da unha encravada e se bobear eu saio de lá sabendo quantos filhos ela tem, quantas vezes ela se casou, que o neto caiu e quebrou a perna. Entendeu, ela é mais assim, ela expõe (M1, F, 35a);

A mulher sem dúvida fala mais. Ela fala que o exame foi dolorido, ou que ela espera que aquele exame seja o último, que ela não tenha que precisar fazer outro (E6, M, 30a);

O homem só responde se você fizer pergunta. Então ele não abre pra você a vida, ou alguma coisa assim que acaba sendo importante pra gente saber (...) a mulher quando você faz uma consulta ou vai conversar alguma coisa com ela, ela se expõe, expõe mais os problemas que ela tem, ela conta mais coisas que às vezes nem tem a ver com o problema, mas pra ela é mais importante falar do que pro homem (E4, M, 30a).

Para as médicas M1(F) e M2(F) o fato de as mulheres falarem mais sobre si mesmas pode ser um fator estressante na interação, assim como o fato de o homem falar pouco. Vejamos o relato:

a mulher se você fizer muita pergunta você vai ficar louco, por que daí você vai dar corda para ela ficar dez horas falando com você. E o homem você tem que estimular ele para estar respondendo, estimular ele a estar respondendo, a falar mais (M1, F, 35a);

A mulher fala mais. A mulher conversa mais. Ela pergunta várias vezes, várias coisinhas pra chegar naquele resultado final. O homem não. Ele vai direito pra entender. A mulher vai e volta, vai e volta (M2, F, 37a);

As entrevistadas E3(F) e E5(F) relatam que prestar cuidado às mulheres é mais difícil, pois embora aceitem os procedimentos, elas exigem mais aos profissionais da saúde:

Olha, eu acho que cuidar da mulher acaba sendo mais difícil, porque, embora ela aceite o fato de precisar de cuidado, ela também te cobra mais esse cuidado (...) No homem a ansiedade dele de acabar logo é tão grande que ele não te cobra muito. Ele não ta muito preocupado se você entrou, se preocupou em cumprimentá-lo ou não, se você conversou com ele ou não, em relação ao atendimento, ele quer que você faça logo pra acabar logo aquele atendimento (E3, F, 31a);

Mas eles acabam aceitando alguns procedimentos com menos argumentos (...) Mulher não, você tem que explicar o porquê, o que vai fazer, o que vai acontecer. Homem não. Ele quer acabar com a dor logo, porque ele quer ir embora (...) acho que a mulher seria um pouco mais difícil, mais complicado. Com a mulher as coisas são um pouco mais difíceis, mas elas são mais fortes, né. Eu acho que elas questionam um pouco mais, então você tem que trabalhar um pouco mais a argumentação (...) Por mais que doa, por mais que sofra é mais fácil 
pedir um procedimento pra um homem do que pra uma mulher. O homem aceita mais rápido. Depois do drama (E5, F, 26a).

Nos relatos das participantes E5(F) e M2(F), é possível notar a percepção de que as mães que acompanham seus/suas filhos/as têm maior dificuldade em colaborar em certos procedimentos médicos indicados para o tratamento de seus filhos doentes e exigem maiores detalhes sobre o diagnóstico e o tratamento:

Mãe é mais difícil, não sei se por ser mais protetora, de ter que defender o filho até o fim. Ah, têm procedimentos que o pai aceita, entende, aceita com mais calma, às vezes a mãe não, vem de imediato falar "credo, que nervoso (E5, F, 26a);

O pai, na consulta é um pouco mais objetivo no que ele quer, quer saber do exame, quer saber o que o exame faz. A mãe não. A mãe da várias voltas pra perguntar a mesma coisa. A mãe é mais prolixa. Consulta com pai é mais objetiva, mais rápida e eu consigo mais efetividade no tratamento. A mãe demora mais tempo pra explicar, mais tempo pra saber alguns detalhes e ela da voltas pra saber o que ela realmente quer saber, pra ela perguntar o que ela quer saber (M2, F, 37a);

Criança mais velha vem com o pai. Bebezinho vem com a mãe. Então os pais são preocupados, são participativos. Mas de uma forma geral, o homem é muito mais direto. Ele pergunta: "vai morrer?" A mulher já é: "ah, qual o problema, mas o que acarreta", pensa se inicialmente ela vai poder fazer as coisas. No final ela pergunta, vai morrer (M2, F, 37a).

A Enfermeira E3(F) acredita que os profissionais da saúde, por se acostumarem com a rotina hospitalar, acabam não observando as diferenças específicas das demandas dos pacientes quanto à exposição do corpo. Ela mesma assume certo egoísmo pessoal que com a rotina diária, desmerece a privacidade, o desconforto e a individualidade da pessoa doente que procura os serviços hospitalares. Vejamos o relato:

pra mim, já virou tão rotina que eu acabo não prestando muito atenção nisso, quer dizer, eu presto atenção, mas eu não dou atenção a isso, não trato muito diferente. Eu até observo, mas o meu egoísmo é maior do que me preocupar com a paciente. Eu acabo tratando como uma rotina minha. E isso eu considero $99 \%$ dos profissionais de saúde, embora alguns digam "ai, eu me preocupo", não se preocupa. Na verdade se preocupa em fazer o procedimento correto. E se preocupar com a individualidade do paciente, se ele ta se sentindo invadido, até pela correria do dia-a-dia mesmo, a gente não tem muito esse tempo (...) A pessoa chega no hospital, a primeira coisa que a gente faz é arrancar a roupa dela, vestir uma camisola com a bunda de fora. Normal, na saúde é assim. Mas pra pessoa não, ela não usa isso todo dia (E3, F, 31a). 
Os relatos das entrevistas E5(F) e M5(F) lembram que a figura do profissional homem ou mulher, pode ter relação com os cuidados prestados a pacientes homens ou mulheres, referem-se às facilidades encontradas quando se trata de um enfermeiro administrar algum procedimento em um paciente do sexo masculino, e de uma enfermeira administrar em uma mulher. De acordo com E5(F), o fato de paciente e profissional serem do mesmo sexo poderia minimizar a vergonha ou o pudor sentido, por parte de ambos, em procedimentos invasivos. Para M5(F) os homens se sentem mais a vontade em interações com médicos em especial quando se trata de queixas sobre os órgãos genitais:

\begin{abstract}
a gente sente que algumas coisas, principalmente na relação homem homem, mulher - mulher é mais tranqüilo. Mas enfermeira com paciente do sexo masculino às vezes dificulta um pouco, dependendo da faixa etária do paciente, se for um jovem adulto, então acho que isso interfere um pouco (....) colocar uma sonda, coloca pela uretra. Então eu acho meio desagradável, mas a gente acaba se acostumando. Assim, profissionalmente falando, pra mim, hoje, o que eu precisar fazer eu faço, sem nenhum problema, mas no início até pra gente é difícil. Além da pessoa ficar envergonhada pela situação, pra gente fazer também é difícil. Então, sempre que é possível, se tem algum procedimento pra fazer num homem, a gente acaba pedindo ajuda pra algum homem. E mulher a gente pede pra mulher fazer, mesmo. Eu acho que é o mais invasivo que eu consigo colocar, porque envolve a parte genital, né (E5, F, 26a);
\end{abstract}

Conversar com um homem eu tenho que explicar pra ele, diferente de quando conversa com uma mulher (...) não são todos os homens que gostam de passar por médicas mulheres (...) Às vezes consulta com um homem, ele não tem nenhuma queixa, principalmente quando se trata da área genital. E ele fala com o meu colega, mais ainda é fechado. Tem uma questão social aí de que a médica é mais de criança e de mulher (...) as mulheres vão ser mais receptivas ao serem atendidas por outra mulher e culturalmente a maioria dos homens, um grupo de homens, vai ter mais dificuldade (M5, F, 37a).

\title{
6.4 Formacão acadêmica relacionada às questões de gênero
}

Os relatos dos participantes apontam que as questões de gênero, bem como as características de homens e mulheres relacionados aos cuidados com a saúde não foram 
abordadas em sua formação acadêmica. Para os participantes esta temática se inserida na formação acadêmica poderia propiciar um preparo maior para o manejo de situações adversas que podem ocorrer no dia-a-dia profissional. Vejamos os exemplos:

não tivemos nada de disciplina ou alguma matéria que abordasse o tema (E1, F, 40a);

Nunca discuti essas questões. Se eu tivesse visto isso na graduação eu conseguiria hoje até me dar melhor com o ser humano (E2, F, 35a);

muito pouco, assim, durante, por exemplo os cursos de ginecologia, obstetrícia, eles sempre tentaram trazer mais a parte ética de cuidado (M3, M, 36a);

Não tive isto no curso. Faz falta até pra entender essa diferença comportamental que existe da paciente internada; quando você sai da faculdade e cai no mercado e tem que lidar com essa coisa, você percebe que a diferença não é insignificante (M4, M, 32a);

E essa diferença de lidar com o homem e lidar com a mulher, é uma coisa que você vai aprendendo no dia a dia. E ninguém nunca chega pra você e te ensina isso: 'olha o homem vai te dar muito mais trabalho que a mulher na prática' (...) No dia a dia, é visível. Você vê a quantidade de medicação pra dor que a mulher precisa e que o homem precisa, o homem precisa de muito mais medicação pra dor (M1, F, 35a);

a universidade abordou, pelo menos pra mim, quando eu fiz, eu acho que de uma forma geral (...) Mas falar de uma disciplina, falando só da saúde da mulher, só da saúde do homem, eu não tive (...) Não tem como a gente tratar igual homem e mulher, né? Então eu acho fundamental fazer essa diferenciação. Não diferença no sentido de um ser melhor e o outro menos. Nada disso, mas realmente pra você saber com o que você ta lidando (E5, F, 26a)

O argumento de E5(F) sobre essa questão é que os cursos de formação em saúde não priorizam o ensino relativo às questões de gênero e o reflexo da ausência deste debate nas instituições de saúde. Para E6(M), a ênfase dada nos cursos de formação está relacionada à saúde da mulher e da criança e segundo M5(F) a ênfase está nas questões éticas. Vejamos os relatos:

Em nada. Até foi falada alguma coisa de somatização, da relação da personalidade e o desenvolvimento de determinadas patologias, mas em relação a gênero, não. Eu acho que não só esse tema como vários outros temas que não relacionavam com a nossa prática. Isso não é discutido, isso não é respeitado (E3, F, 31a); 
hoje tem muitas disciplinas que falam da saúde do adulto, hoje as disciplinas, falam muito do adulto, envolvendo a mulher, o homem e a criança. Mas dá muita ênfase hoje, as grades curriculares, à saúde da mulher e à saúde da criança (E6, M, 30a);

Existe uma falha muito grande na questão do relacionamento. Quando você discute a questão da relação médico-paciente, fica mais do ponto de vista ético, no que do ponto de vista de como você poderia fazer pra ter naturalmente essa relação médico-paciente (M5, F, 37a).

M2(F) aponta que as discussões sobre questões de gênero e saúde não são comuns em seu cotidiano. Para a entrevistada há um foco sobre gênero nos programas de prevenção à saúde quando se enfatiza a prevenção ao câncer ginecológico na mulher do que o câncer de próstata no homem:

Da forma como você ta me colocando não existe a discussão dessas diferenças, diferenças e gênero, né. Tem que tomar cuidado com a mulher, tem programa médico e convênio, que cuida da saúde da mulher. Então qual é o grande enfoque? É a campanha de cólon de útero, mais voltada pra área ginecológica. Eu ainda não vi nenhum programa relacionado ao homem. Existe sim uma campanha que é veiculada aí, falando do câncer de próstata, mas não existe a mesma preocupação e a da mulher já existe há mais tempo (M2, F, 37a).

Para E4(M), a experiência cotidiana em detrimento do estudo acadêmico subsidiou seus conhecimentos sobre o comportamento masculino ou feminino referente às questões da saúde:

Não tem nenhum estudo que comprove isso que eu tenha feito, mas observando eu acho que é isso que acontece, porque a gente conversa quando a gente ta com os pacientes, a maioria a gente percebe. Você vai percebendo no homem e no mundo, né. Só a parte física, anatômica. Parte de como lidar com o homem, com a mulher, não estudei (E4, M, 30a).

É importante ressaltar que concepção sobre gênero na área da saúde reflete a prática profissional dos/as médicos/as e enfermeiros/as entrevistados/as no atendimento de homens e mulheres. No entanto, não podemos desconsiderar que os profissionais são também pessoas que se reconhecem como homens e mulheres, que foram construídos pelo mesmo processo de socialização e cultura de padrões hegemônicos de gênero e, portanto, 
tem suas concepções pessoais que influenciam o modo como percebem o gênero de seus pacientes. Isso pode ser uma variável que também interferiu a compreensão de gênero na atuação profissional dos nossos entrevistados. 


\section{DISCUSSÃO}

De modo geral, para os entrevistados o gênero se configura como uma forma de agrupar e diferenciar de acordo com características que sejam semelhantes. Nos relatos dos/as médicos/as e enfermeiros/as é possível perceber que suas concepções se assemelham as definições conceituais de gênero apresentadas no dicionário da língua portuguesa e em discursos diversos do senso comum. Entretanto, sabemos que tais definições não englobam a dimensão política que está por trás da diferenciação de gênero, própria dos estudos atuais sobre relações de gênero. Se por um lado o gênero seria, segundo os entrevistados, fruto da composição genética do macho ou da fêmea, por outro há a percepção dos fatores sócio-culturais que também o constituem, embora essa percepção seja superficial e naturalizada porque não se aborda essa diferenciação como fruto de uma concepção histórica e política maior, como defendem Moro (2001) e Lamas (2000).

Dizendo de outro modo, o termo "gênero" foi utilizado pelos participantes para se referir ao sexo biológico (gênero masculino e gênero feminino) a partir de ideias, percepções e atributos criados nas relações sociais que visam diferenciar homens e mulheres, de acordo com os seus atributos comumente observáveis no cotidiano. No entanto, as concepções não descrevem claramente o gênero como a organização social das diferenças sexuais que em seu caráter histórico irá fundamentar e ser fundamentado por representações de masculino e feminino (SCOTT, 1995). Denota-se disso o conhecimento das diferenças sem, contudo compreender profundamente os seus determinantes e tampouco a repercussão do gênero na formação da identidade dos indivíduos.

As mulheres foram vistas como possuidoras de habilidades pessoais e subjetivas tais como: pacientes, meigas e carinhosas; além disso, também foram vistas como pessoas com dificuldade para compreender o mundo ao seu redor e pouco racionais e objetivas e, 
por isso, exercitam mais o diálogo, a curiosidade e a necessidade de obter detalhes nas informações. O feminino foi definido com dotado de atributos, tais como, sensibilidade, desatenção, delicadeza, emotividade, carinho, cuidado e maternidade e o masculino com agilidade, racionalidade, vergonha em demonstrar emoções, invulnerabilidade, competitividade, frieza, força e responsabilidade com a manutenção financeira da família. Em geral, as características femininas parecem mais vantajosas, entretanto, as características masculinas vantajosas ou não, ainda se baseiam em concepções enraizadas nas sociedades patriarcais, como já comentaram os autores (REIS, 2008; VAITSMAN, 1994; WHITAKER, 1995).

Os atributos masculinos e femininos identificados pelos entrevistados reproduzem os estereótipos já descritos em outros estudos das representações sociais sobre homens e mulheres (AFONSO, 1995; COUTO et al, 2006; MORO, 2001; SILVA; GUARIDO; GRACIANO, 1976; REIS, 2008). Sabemos que a construção de estereótipos de gênero denuncia a construção cultural sobre o que se define ser homem e ser mulher, especialmente em estudos antropológicos que mostram as diversas formas de representar e lidar com o corpo em função de organizações sociais e culturais (MEAD, 1979; MENEZES; HEILBORN, 2007; SARTI, 2001).

A socialização diferenciada de meninos e meninas foi entendida pelos profissionais entrevistados com um fator influente no desenvolvimento dos atributos tal como se referem os estudos de Meyer (2003a; 2003b), Graciano (1978), Louro (2003) Hidalgo e Palácios (2004) e Whitaker (1995). A cultura por delimitar papéis, reprimi o acesso a ambientes e a situações que possam estimular o desenvolvimento de certos comportamentos e valores, alimentando a ideia de que homens e mulheres devem ter condutas diferentes entre si, e isto irá fortalecer a lógica discriminatória e opressora das relações de gênero. Essa lógica é presente nos processos de socialização e educação 
familiar e escolar (GRACIANO, 1978; HIDALGO; LOURO, 2003; MEYER, 2003a; 2003b; MORO, 2001; PALACIOS, 2004; WHITAKER, 1995).

Ainda que alguns dos participantes tenham identificado o papel da socialização e da estrutura cultural na construção do gênero, há aqueles que outorgam à genética o papel decisório sobre o que é ser homem ou ser mulher. No entanto, essas compreensões não se encontram fundamentadas em estudos científicos e sim em observações pessoais ou em leituras não acadêmicas baseadas no discurso do senso comum e do discurso médico do século passado, tal como comenta a autora Rohden (2003). E, como afirmam Magalhães e Ribeiro (2009) existem materiais de divulgação científica que buscam legitimar a diferença existente entre homens e mulheres através da composição biológica, sem considerar que a própria construção da diferença biológica é enviesada por aquilo que culturalmente se entende como masculino e feminino (LAQUEUR, 2001).

Quanto ao processo de diferenciação dos gêneros, a adolescência foi apontada como marco para a finalização e fortalecimento dessa diferença e isso pode ter relação com a ideia de que as bases hormonais definem o comportamento. É a partir da adolescência o corpo reprodutivo da mulher torna-se um motivo de preocupação e de cuidado. A adolescência também é momento no qual as expectativas sociais condizentes ao sexo e ao gênero tornam-se consideravelmente mais incisivas e vistas como necessárias a adequação do sujeito em seu grupo social (OLIVA, 2004a; 2004b).

Martins (2004) e Rohden (2002; 2003) destacam que ainda existe a concepção equivocada de que diferentemente do homem, a mulher se afetaria mais com as mudanças da puberdade, gravidez e menopausa, devido à sua fisiologia vulnerável e isto também é abordado no relado de dois entrevistados. Lamas (2007) e Graciano (1978) argumentam que durante seu desenvolvimento homens e mulheres são educados em função das naturezas distintas devido às crenças baseadas em estereótipos de gênero. Assim, as 
relações de poder, delimitam o acesso e também as possíveis opções por parte daqueles sujeitos que se enquadram no construto tido como "masculino - homem" ou "feminino mulher”. Para Bordo (1997), disso resultam as situações de estratificação, violência e repressão de acordo com o gênero.

A repressão feita pelos dispositivos de controle visa fortalecer a hegemonia sobre o que é ser homem e ser mulher produzindo discriminação e preconceito sobre aqueles que não correspondem aos padrões hegemônicos de masculinidade ou de feminilidade (CONNELL, 1995; FOUCAULT, 1981; KORIN, 2001). Ao longo de todo o ciclo vital a sociedade irá exigir, por meio de expectativas e valores, os comportamentos condizentes ao sexo biológico (GRACIANO, 1978; HIDALGO; PALACIOS, 2004). Porém indivíduos que possuem perfis andrógenos parecem adaptar-se melhor a diferentes situações e tarefas sociais ao longo da vida mesmo que sofrendo discriminação e preconceito social (OLIVA, 2004a; 2004b).

Acreditamos que no dia-a-dia destes profissionais os atributos identificados como tipicamente masculinos ou femininos podem influenciar sobremaneira nas interações com pacientes homens e mulheres, uma vez que usualmente há generalizações de estereótipos entre aqueles que pertencem a um ou outro sexo. A noção de gênero e as representações estereotipadas sobre o masculino e o feminino, influenciam diretamente nos comportamentos interpessoais a serem adotados e esperados socialmente e irá conduzir a forma como os indivíduos devem perceber com o corpo e com o cuidado prestado (CONNELL, 1995; COURTNAY, 2000; DOYAL, 2001; GOMES, 2003; KORIN, 2001; UNBEHANUM, 2003).

Segundo alguns dos participantes há momentos nos quais a masculinidade ou a feminilidade não são manifestados de modo rígido e estereotipado e há uma percepção de que ser homem ou ser mulher é uma questão flexível, quando explicitam atributos tidos 
como femininos aos homens e vice-versa. Essa "mistura" de atributos parece confundir as representações estereotipadas e sinaliza a fragilidade existente nas representações hegemônicas de homem e de mulher, em especial entre aqueles que concebem a diferença unicamente pelas condições genéticas dos sexos (BUTLER, 2008; COUTO et al, 2006; LAMAS, 2000).

A aprendizagem decorrente dos processos de instrução sobre o corpo produz relações distintas entre a função, a necessidade e o manejo do corpo de acordo com o sexo biológico. Homens e mulheres aprendem a perceber e a lidar de maneira diferente com seu corpo. Ao longo da história, o corpo masculino esteve socialmente representado como saudável, ativo e resistente em contraste do corpo feminino tido como frágil, instável e sensível a doenças. O resultado dessas representações fica visível pelo fato de que homens e mulheres lidam de maneira distinta com a saúde e com os cuidados corporais e esse dado também foi verificado entre os relatos dos/as profissionais entrevistados/as.

Denota-se nos relatos a noção de que mulheres seriam mais predispostas ao contágio de doenças devido sua condição corporal. O corpo feminino, sua anatomia e fisiologia foram vistos como mais vulneráveis. Este dado vai ao encontro dos estudos de Rohden (2002; 2003) e Martins (2004) nos quais, de um ponto de vista histórico, as ciências médicas vêm construindo e mantendo a ideia do corpo feminino como mais frágil e predisposto a doenças.

A concepção de que as mulheres são mais sensíveis às doenças teve um papel importante nas ciências médicas, pois estimulou criação de uma especialidade que garantisse os cuidados sobre a suposta fragilidade feminina. $O$ tratamento da vulnerabilidade feminina preveniria danos à reprodução e garantiria o desenvolvimento social (MARTINS, 2004; ROHDEN, 2007). Desta forma, baseando-se nos princípios de 
vulnerabilidade, as mulheres foram e ainda são educadas para cuidar do corpo de forma mais frequente uma vez que devem garantir sua saúde reprodutiva.

Os relatos indicam a maior procura da mulher por serviços de saúde, para os entrevistados elas estão em maior número nas unidades de atenção primária e secundária. De acordo com os dados das entrevistas as mulheres cuidam mais de sua saúde. A revisão bibliográfica confirma esta percepção dos entrevistados e aponta que as mulheres consomem maiores quantidades de medicamentos, utilizam mais os serviços de saúde do que os homens de maneira preventiva e remediativa. Por um lado, isto parece resultar e menores taxas de mortalidade da população feminina e, por outro, também pode levar a uma situação de saúde desfavorável, pois pode ocasionar em um excesso de uso medicamentoso de drogas por parte das mulheres (FIGUEIREDO, 2005; KORIN, 2001; MENDONÇA et al., 2008; PINHEIRO et al., 2002).

O cuidado das mulheres com seu corpo parece ser intermediado tanto pelo discurso científico que apregoa determinados cuidados necessários, quanto pelas intervenções e exames que pretensamente monitoram a mulher sobre sua condição física. Como se refere Martin (2006) o conhecimento sobre o próprio corpo ocorre somente com o intermédio de uma segunda pessoa - o profissional da saúde. Portanto precisa-se do discurso científico, do médico e das intervenções para lidar e compreender o próprio corpo.

O discurso biomédico sobre a saúde da mulher e sua sexualidade torna-se dispositivo de controle levando ao uso excessivo de medicamentos e cirurgias e tornam as mulheres mais acessíveis e responsivas às políticas de saúde coletiva (KRIEGER; FEE, 1994; MARTINS, 2004; MENDONÇA et al., 2008; PEREIRA, 2007; PINHEIRO et al, 2002; RABASQUINHO; ROHDEN, 2002; 2003; 2007).

As mulheres foram descritas como mais claras e específicas ao falar de seus problemas de saúde. Segundo os relatos as mulheres aceitam mais os tratamentos e as 
terapêuticas. De acordo com os estudos de Rohden (2002; 2003) e Vieira (2002) esse fato pode ser fruto da educação diferenciada, orientada pelo discurso médico, e das experiências vividas ao longo de seu desenvolvimento, que estimulam a expressão de fragilidade e a monitoração sobre sua condição física. Nos relatos é identificado o fato de que as mulheres não possuem orgulho de demonstrar fragilidade e nem vergonha de se expor aos cuidados de outra pessoa, tampouco reclamam quando submetidas a procedimentos invasivos ou dolorosos. Novamente temos a influência da expressão da fragilidade, permitida às mulheres, e das repetidas experiências de submissão aos cuidados médicos que provavelmente levam as mulheres a se acostumarem com estas situações desde a adolescência (KORIN, 2001; MARTIN, 2006; ROHDEN, 2002; 2003).

As concepções dos participantes argumentam que a mulher, por se sentir como a principal responsável pelos filhos, teria medo de não poder executar seu papel caso desenvolva algum problema grave de saúde. Isso lhes aproximaria dos cuidados preventivos, pois assim poderiam evitar acometimentos severos e garantir sua função de mãe. Talvez os estudos da Etologia (LORENZ, 1995) possam explicar a responsividade materna com a prole, mas para Ribas e Moura (2004) e Azevedo e Arraias (2006) as hipóteses etológicas seriam simplistas, pois como apontam os estudos atuais, existem variáveis que podem interferir na prevenção e na preocupação em se manter saudável para cuidar de filhos e isso pode ocorrer entre mulheres e também entre homens.

Parece haver uma tendência ao homem se responsabilizar pela saúde de seus filhos e isto poderia aproximá-lo mais dos serviços de saúde. Provavelmente homens mais responsivos aos cuidados com os filhos podem apresentar certas características vistas como femininas podendo ser vivenciada como discriminação, pois confronta os atributos da masculinidade hegemônica. Gomes (2003) e Nolasco (1993) observam a luta do feminismo para inserir a mulher em atividades públicas contribuiu para a aproximação do 
masculino aos papéis privados e domésticos, no entanto o modelo de masculinidade hegemônica parece ter grande influencia sobre o reconhecimento do exercício masculino de atividades domésticas e parentais (GOMES, 2003; TELES, 1999).

Podemos dizer que foi predominante a idéia de que as mulheres sejam mais fortes diante da doença, mas um dos relatos indica a percepção de que mulheres também são dependentes e solicitam mais a presença de familiares durante a internação. A forma como as pessoas manifestam sua queixa está sujeita às regras sobre o que é socialmente permitido e esperado para cada gênero e nos parece claro que em nossa cultura existe uma permissividade maior para a demonstração de fragilidade e fraqueza por parte das mulheres (ALVES; FIGUEIRAS, 2007).

Os dados apontam também a valorização estética como um fator que aproximaria a mulher aos serviços de saúde. Tal concepção pode estar relacionada a valores culturais que vinculam o ideal de saúde, beleza e o bem estar à medicalização e ao consumo de serviços de saúde. Para se sentirem bem e bonitas as mulheres necessitariam de cuidar da saúde e esse cuidado parece ocorrer por meio das intervenções, sejam elas cirúrgicas ou medicamentosas. Retomamos o ponto de vista de Bordo (1997):

\begin{abstract}
nós, mulheres, estamos gastando muito mais tempo com o tratamento e a disciplina de nossos corpos como demonstram inúmeros estudos. (...) através da busca de um ideal de feminilidade evanescente, homogeneizante, sempre em mutação - uma busca sem fim e sem descanso, que exige das mulheres que sigam constantemente mudanças insignificantes e muitas vezes extravagantes da moda. (...) os corpos femininos tornam-se o que Foucault chama de "corpos dóceis": aqueles cujas forças e energias estão habituadas ao controle externo, à sujeição, à transformação e ao "aperfeiçoamento". (...) Por meio de disciplinas rigorosas e reguladoras sobre a dieta, a maquiagem, e o vestuário somos convertidas em pessoas menos orientadas para o social e mais centradas na automodificação. (BORDO, 1997 p. 20)
\end{abstract}

Nesse sentido as formas, atos e padrões estéticos de utilização do corpo configuram rituais de cuidados que envolvem os serviços de saúde, que por meio de seu discurso, fixam certos modos de ser, sentir ou de agir (SARTI, 2001). 
Podemos identificar, segundo os relatos, que o homem também foi visto como um indivíduo vulnerável pelo fato de não manter hábitos de cuidados com a saúde. Os estudos respaldam esta concepção ao apontar os homens como possuidores de uma expectativa de vida ao nascer sempre menor quando comparada a das mulheres, e taxas de mortalidade por faixa etária apontam uma maior mortalidade masculina em todos os grupos etários. Segundo os participantes entrevistados, os homens estariam em maior quantidade nas unidades de internação. Nesse sentido, os serviços e as políticas de saúde coletiva parecem não repercutir entre os homens quando se trata de prevenção, corroborando com as pesquisas brasileiras e norte americanas que apontam um número maior de homens internados em situação grave (BIRD; RIEKER, 1999; FIGUEIREDO, 2005; MANCINTYRE et al., 1996; MANCINTYRE et al., 1999; PINHEIRO et al., 2002; VERBRUGGE, 1982).

Na concepção dos entrevistados os homens seriam mais objetivos ao falar de seus problemas, porém parecem ter mais dificuldade em detalhar os sintomas e descrever suas queixas. Segundo os relatos, os homens apenas procuraram por serviços de saúde quando o seu estado de físico já está significativamente comprometido. Ao contrário das mulheres, o público masculino parece possuir dificuldade em deixar que uma segunda pessoa cuide de sua saúde. Estes dados corroboram com as pesquisas que evidenciam a menor procura masculina por serviços de atenção primária. A procura só ocorreria em casos avançados de acometimento, reduzindo a eficácia dos tratamentos entre essa população. Por este fato os homens hospitalizados possuem piores condições de saúde em relação às mulheres (COSTA-JÚNIOR; MAIA, 2009; GOMES, 2003; 2008; GOMES; NASCIMENTO; ARAÚJO, 2007).

Para os participantes os cuidados com a saúde se referem basicamente em procurar atendimento médico preventivo, seguir as prescrições médicas e se manter disponível às 
intervenções. E são justamente estes cuidados que os participantes identificam como ausentes na população masculina, homens preferem cuidar de sua saúde de forma individual e rápida (CONNELL 1995; COURTENAY, 2000; FIGUEIREDO, 2005; KORIN, 2001; PINHEIRO et al., 2002; UNBEHANUM, 2003).

De acordo com as pesquisas de Travassos et al. (2002), Pinheiro et al. (2002) e Korin (2001) a busca masculina por serviços de saúde é substancialmente inferior à busca realizada pelas mulheres assim como existe uma visível diferença na atenção oferecida aos homens. Com o lançamento da política nacional de atenção integral a saúde do homem no ano de 2009, espera-se que os serviços se adequem às peculiaridades desta população, tanto na integralidade do atendimento e na capacitação técnica dos profissionais da saúde quando na elaboração de novas concepções que abordem as diferentes masculinidades.

Segundo Braz (2005) os homens, de modo geral, recorrem a farmácias ou prontosocorros, devido a rapidez destes serviços, e relatam não se sentirem acolhidos em outros locais de atendimento pois percebem que estes serviços não se preocupam em atender suas necessidades (GOMES; NASCIMENTO; ARAÚJO, 2007; FIGUEIREDO, 2005).

De acordo com os participantes, o público masculino valoriza a rapidez do atendimento de modo que a permanência no serviço de saúde seja breve. O tempo de espera por atendimento resultaria em afastamento prolongado do local de trabalho e com isso a necessidade de justificativa, ou seja, relatar um possível acometimento físico. Segundo os dados das pesquisas de Costa-Júnior e Maia (2009) e Gomes, Nascimento e Araújo (2007) os homens estariam mais preocupados com o trabalho, pois fatores associados ao emprego e a competitividade no mercado de trabalho aparecem nas pesquisas como uma variável que atrapalha os homens a buscarem por atendimento médico. $\mathrm{O}$ contexto de trabalho, não parece ser receptivo às manifestações de doenças por 
parte dos homens e se afastar do trabalho por motivos de doença poderia resultar em um desmerecimento do homem enquanto inapto para suas atividades laborais.

A demonstração de fragilidade ou adoecimento físico produziria conseqüências negativas para os homens e isto parece estar relacionado com os atributos de força, virilidade e resistência tidos como tipicamente masculinos (BRAZ, 2005). Desde a infância os homens são ensinados a ocultar seus sentimentos ou fraquezas e são valorizados ao demonstrem força, resistência e virilidade. Desta forma, se culturalmente temos a fragilidade física como um atributo feminino as faltas das mulheres no trabalho, ocasionadas pela procura de serviços de saúde, não produziriam tanto desconforto.

Entre os entrevistados também há a concepção de que a vulnerabilidade não estaria diretamente relacionada ao gênero, mas sim aos hábitos de vida. Sabemos que os hábitos podem variar de acordo nível sócio econômico, escolaridade e papel exercido na vida pessoal.

Travassos et al. (2002) demonstram que fatores tais como grau de escolaridade, nível social e grau de responsabilidade financeira para com a família também estão diretamente relacionados com a menor utilização masculina dos serviços de saúde e esses fatores foram identificados pelos entrevistados. No argumento de Travassos et al. (2002) ser homem, pertencer a classe baixa, estar empregado no setor informal da economia e ser chefe de família são os critérios que predispõe a menor utilização de serviços de saúde por parte dos homens. Cabe ressaltar que as mulheres chefes de família também apresentam menor consumo desses serviços (TRAVASSOS et al., 2002). Nesse contexto, a necessidade em cuidar da saúde está distante do cotidiano masculino, especialmente de homens de menor poder aquisitivo e que não sofrem de doenças crônicas (TRAVASSOS et al., 2002; VERBRUGGE, 1989). 
Os participantes relatam que durante as internações os homens são mais queixosos e mais dependentes. Isto parece conflitar com a noção de força, vigor e resistência tida como atributo masculino. Uma vez que não foram educados e acostumados com as intervenções e por evitá-las ao máximo esses indivíduos teriam maior dificuldade em lidar com o desconforto e isso produziria a queixa. Concomitante a isto parece haver uma dificuldade dos profissionais da saúde em acolher as queixas masculinas uma vez que as vêem como exageradas e desnecessárias. A masculinidade hegemônica apresenta como modelo ideal, homens ativos, fortes e capazes de trabalho físico árduo. Características que saiam dessa prescrição são consideradas tipicamente femininas e, portanto, punidas. Homens que apresentam tais características são vistos como fracos, afeminados ou homossexuais (CONNEL 1995; GOMES, 2003; KORIN, 2001; MAIA; MAIA, 2009; NOLASCO, 1993). Como nos apontam Rohden (2001; 2003), Mosse (1998) e Martins (2004) a forma como as instituições de saúde diferenciam homens e mulheres fortalecem o estabelecimento de padrões normativos socialmente considerados "adequados", referentes a um ou outro sexo biológico e respaldaram a discriminação dos "desviantes".

Diante dos relatos podemos constatar a dificuldade dos profissionais em lidar com pacientes do sexo masculino. O fato de os homens não falarem claramente sobre seus sintomas e por não seguirem o tratamento indicado, torna a relação profissional-paciente mais desgastante. A interação com pacientes mulheres é vista como mais satisfatória uma vez que os profissionais percebem uma maior adesão às prescrições e também maior eficácia no tratamento. Os atributos femininos parecem facilitar a interação e isto pode repercutir na manutenção do vínculo das mulheres com os serviços de saúde.

Os estudos sugerem que os homens são menos propensos a reportar problemas de saúde ao seu grupo de apoio e aos profissionais da saúde (CONNELL, 1995; COSTAJÚNIOR; MAIA, 2009; GOMES, 2003; KORIN, 2001; MACINTYRE et al., 1999). Sobre 
esta concepção podemos especular acerca da hipótese de o atendimento prestado a homens ser qualitativamente inferior ao prestado às mulheres, pois esta população é vista a priori como menos responsiva aos cuidados prestados pelos profissionais. E isso pode repercutir na manutenção da hesitação masculina em buscar os serviços de saúde. Esta dificuldade dos profissionais da saúde remete aos mesmos dados apontados nos estudos de Afonso (1995) nos quais as educadoras tendem a considerar meninas mais carinhosas e mais fáceis de lidar.

Estudos feitos com homens em situação de internação ou em busca por atendimento médico apontam que os homens não se sentem acolhidos nessas situações, ou seja, parece que não há uma compreensão de suas necessidades tampouco estratégias para lidar com suas dificuldades em falar sobre si. Os homens entrevistados nesses estudos reconhecem que a cultura atual disponibiliza mais informações sobre saúde às mulheres e também dá maior suporte para que essas procurem os serviços de saúde (COSTAJUNIOR; MAIA, 2009; GOMES; NASCIMENTO; ARAÚJO, 2007). Nesse sentido há uma maior instrumentalização por parte das mulheres para entender e abordar suas demandas em saúde.

Em relação aos cuidados com a saúde, os estudos apontam que embora vivam mais, as mulheres tendem a reportar mais morbidade e problemas psicológicos (ALVES; FIGUEIRAS, 2007; MANCINTYRE et al., 1996; MANCINTYRE; FORD; HUNT, 1999; VERBRUGGE, 1982; 1989). Esse fato foi identificado nos relatos quando os participantes descrevem as mulheres como mais questionadoras e mais prolixas. Tais atributos foram caracterizados como estressantes na interação com essas pacientes, pois as consultas seriam mais demoradas e as mulheres exigiriam mais explicações sobre os procedimentos, ainda que os aceitem com mais facilidade. As mães que acompanham seus filhos também são vistas como mais difíceis de lidar, pois exigem mais dos profissionais. 
Segundo uma das enfermeiras entrevistadas os profissionais da saúde e a própria estrutura dos serviços não lidam com as diferenças entre os gêneros tampouco consideram as particularidades de cada paciente, especialmente quando é preciso expor o corpo. Denota-se disto o fato de que aqueles sujeitos que não correspondem aos critérios de normalidade estabelecidos pela cultura podem sofrer maior exclusão destes serviços uma vez que suas especificidades não são atendidas e respeitadas. Desse modo, como nos lembra Sarti (2001), a forma como o profissional reage diante dos comportamentos do doente influencia na própria reação do paciente diante do tratamento.

A exposição do corpo e a manipulação do corpo sexual parece ser uma situação desconfortável na relação profissional-paciente. Os profissionais parecem compreender que há facilidades significativas quanto ao fato de um profissional homem fazer um procedimento em um paciente homem, pois haveria um menor desconforto desse na exposição ou manipulação dos seus órgãos sexuais. O mesmo ocorreria com mulheres, no entanto, elas parecem ser mais receptivas mesmo quando se trata de profissionais do sexo masculino. O desconforto ocasionado nessas situações de exposição e pudor pode gerar condutas de esquiva, levando os profissionais a encaminhar a um/a colega de trabalho a administração do procedimento, evitando assim uma situação de mal-estar por parte de ambos. Também podemos supor que nesse cenário há um maior reconhecimento do papel do médico homem do que da médica mulher e isso pode estar relacionado ao fato de as ciências serem historicamente desenvolvidas e difundidas por homens. Como afirma Moro (2001). Segundo essa autora no contexto educacional, os professores tendem a considerar de maneira mais positiva as produções acadêmicas de meninos em detrimento das meninas, e isso claramente resulta em um maior engajamento dos meninos nas atividades de pesquisa e na produção científica. 
As informações coletadas nas entrevistas apontam a ausência da discussão sobre o gênero na formação acadêmica dos participantes. Parece haver a referência do gênero como um aspecto meramente biológico nos cursos de formação em medicina e enfermagem. Segundo os relatos o enfoque é dado à saúde da mulher e provavelmente isto se deve a existência de especialidades médicas que visam atender demandas específicas do corpo sexual e reprodutivo da mulher, no caso a ginecologia e obstetrícia (ROHDEN, 2003).

As consequências da inexistência de uma formação pautada também nas questões de gênero parecem interferir diretamente no preparo destes profissionais para lidar com as demandas específicas do homem e da mulher que estejam para além do corpo biológico. Nesse sentido o corpo parece ser entendido como um aparato orgânico desprovido de significados sociais, construídos historicamente, e enviesado pelas concepções dominantes sobre masculinidade e feminilidade (LAMAS, 2007; MENEZES; HEILBORN, 2007).

Segundo os dados os participantes relatam ter conhecimento da diferença entre homens e mulheres quanto aos cuidados com a saúde somente na sua atuação profissional. Os resultados indicam que a diferença biológica é amplamente abordada nos cursos de formação, no entanto, o manejo diário de pacientes, homens e mulheres, implica em outras habilidades interpessoais e em conhecimentos acerca da diversidade das construções de identidade que estão para além das definições restritas à diferença sexual ou anatômica. Sobre esse aspecto os participantes consideraram sua formação acadêmica insuficiente.

Em estudos anteriores (COSTA-JUNIOR; MAIA, 2009; GOMES; NASCIMENTO; ARAÚJO, 2007) a relação entre gênero e saúde também foi evidente no relato de homens hospitalizados, quando eles assumiram cuidar menos da saúde e depender das mulheres para isso e ou para o tratamento de sua doença. Podemos dizer que essa percepção não se restringe aos pacientes, pois nesse estudo, os cuidadores, 
médicos/as e enfermeiros/as também percebem a mesma situação diferenciada no atendimento de pacientes homens e mulheres.

Novos estudos poderiam ampliar a discussão ouvindo as mulheres cuidadoras ou mesmo os cuidados com a saúde de infantes, uma vez que a construção do gênero foi relatada para muitos como algo que se diferencia mais na infância e na adolescência. Ou ainda, aprofundar a relação de gênero na saúde considerando a própria construção de gênero de quem é o profissional e que de quem é o paciente ou também investigar como ocorre a formação específica do profissional que atende na área da saúde no que tange ao estudo de gênero nas ciências médicas.

Dentre os possíveis temas a serem investigados nesta temática se encontram a medicalização do corpo feminino, bem como a procura das mulheres por cirurgias estéticas ou terapêuticas. Na bibliografia consultada podemos perceber o amplo referencial teórico a respeito da medicalização da mulher, no entanto pode ser relevante investigar o ponto de vista das próprias mulheres sobre sua medicalização, para com isso analisar a forma como as redes de controle e normatização determinam a construção das identidades femininas quanto ao uso do corpo e a submissão aos procedimentos invasivos sejam eles terapêuticos, estéticos ou medicamentosos.

A formação profissional e também o desenvolvimento de novas metodologias que capacitem uma atuação profissional pautada nas questões de gênero poderiam ser investigadas em estudos e intervenções. Tais pesquisas contribuiriam para a melhor adequação das práticas profissionais quanto às questões de gênero e atualizariam o discurso das ciências da saúde com as novas produções científicas, minimizando a influência do paradigma discriminatório, superficial e patologizante ainda presente no contexto da saúde. 
Os dados apontados por este estudo podem ser inovadores no sentido de levantar as concepções dos profissionais da saúde sobre as questões de gênero e sua relação com os cuidados prestados e recebidos no contexto da saúde. A análise das falas dos entrevistados pôde demonstrar o quanto o gênero, mesmo sendo uma condição influente na forma como homens e mulheres lidam com a saúde, ainda está longe de ser um tema abordado na formação e nos contextos de saúde. Percebe-se que a inclusão do gênero nos currículos de formação poderia subsidiar a capacitação dos profissionais da área para que assim se promova a assistência integral atendendo às demandas humanas em sua complexidade e diversidade.

\section{CONSIDERAÇÕES FINAIS}

Nos relatos há uma percepção sobre a relação direta entre questões de gênero e saúde de homens e mulheres, favorecendo mais as mulheres quanto aos cuidados com o corpo e com a prevenção de doenças, aos tratamentos e diálogos sobre o diagnóstico da enfermidade e também na facilidade de atendimento na relação entre os/as profissionais e as pacientes. No entanto, em sentido oposto a educação de cuidados com a saúde dada à mulher também parece colocá-la em uma posição se medicalização excessiva. O uso desnecessário de terapêuticas pode ser visto como fruto da constante administração do corpo vivida pelas mulheres e também como um fator que as distancia de uma autonomia para cuidar do próprio corpo.

A partir das análises desse estudo percebe-se que as diferenças de gênero são compreendidas pelos médicos/as e enfermeiros/as a partir das experiências diárias da profissão. Essa percepção é ora baseada em fatores orgânicos e anatômicos, ora pelas características físicas, comportamentais e sociais, especialmente influenciadas pela educação de familiares. No entanto, não há uma compreensão abrangente da categoria 
gênero como uma construção histórica de cunho político e social que define e irá ser definida por aquilo que se entende como homem e mulher, como corpo masculino e corpo feminino.

A postura profissional adotada frente às diferenças comportamentais de homens e mulheres acaba por ser entendida como uma forma necessária e eficiente para lidar com as singularidades. No entanto, a interação profissional-paciente parece reiterar as desigualdades de gênero, reproduzindo o cenário discriminatório da presente cultura. $\mathrm{O}$ atendimento prestado pode ser diferente, mas está baseado na naturalização das demandas específicas do gênero e não aborda ou questiona a complexa determinação cultural de tais diferenças.

O paciente homem foi visto como queixoso por constantemente solicitar a presença dos profissionais ou familiares e também por não saber lidar com dores e restrições do tratamento. Quanto a esta concepção vale indagar se a máxima "homem não chora" estaria resvalando em expectativas dos profissionais quanto ao comportamento do pacientes homens. Ou seja, homens se queixam mais ou os profissionais são mais sensíveis às suas queixas por simplesmente esperar que eles não devessem se queixar? Novos estudos poderiam subsidiar uma discussão consistente focada nessa questão e descrevendo a reprodução de discriminações.

A exposição do próprio corpo e a manipulação do corpo de outrem parece ser um dificultador nos cuidados em saúde. Tabus e preconceitos permeiam as concepções dos profissionais e seus pacientes gerando desconforto e evitação, e por sua vez, reiteram o distanciamento entre os cuidados a serem prestados ou recebidos por uma pessoa do sexo oposto.

O corpo como uma construção social não é somente produto dos fatores biológicos que o constituem, mas, sobretudo uma expressão de humanidade, pois traz em sua 
formação inúmeros valores e normas vigentes na cultura. Esse corpo cultural e histórico deve ser compreendido e atendido em suas diferentes especificidades. As tecnologias em saúde ao longo dos anos aprimoraram as técnicas de intervenção sobre o corpo biológico sem considerar os constituintes culturais do corpo e dos cuidados a ele prestado. Parece evidente que a eficácia dos cuidados preventivos e terapêuticos depende do entendimento do corpo e do cuidado em sua total complexidade.

A formação acadêmica é reconhecida pelos médicos/as e enfermeiros/as como precária e insuficiente para discutir a questão de gênero e sua relação na prática profissional. Cabe destacar que a formação acadêmica promovida atualmente pelas instituições de ensino superior não parece dar a devida importância nas temáticas relativas à construção histórica e social do gênero e a sua relação direta sobre as condições de saúde e nos serviços disponíveis à população.

Além disso, é preciso considerar o respeito à diversidade, especialmente, quanto às diferentes masculinidades e feminilidades a serem reconhecidas e abordadas pela assistência dos serviços de saúde. Nesse princípio, a saúde do homem e a saúde da mulher, ao englobar o caráter das múltiplas constituições das identidades masculinas e femininas deveriam ser denominadas como "a saúde das mulheres" e a "saúde dos homens", uma vez que não se refere a uma única configuração concisa de feminino e de masculino, pois homens e as mulheres se constituem de maneiras múltiplas. A própria mudança da nomenclatura ajudaria a sinalizar a diversidade e assim diminuir o poder normalizador das concepções hegemônicas que fundamentam e sustentam as idéias e valores sobre o que é ser homem e ser mulher.

Conclui-se que é preciso investir na formação acadêmica desses profissionais incluindo uma discussão profunda sobre sexualidade, educação sexual e gênero uma vez que essas questões fazem parte do cotidiano na área da saúde. Além disso, as políticas 
públicas deveriam investir em processos que considerem as atitudes preventivas e de adesão ao tratamento em função de padrões hegemônicos e rígidos de gênero e que dificultam, muitas vezes na relação com os cuidados com a saúde, bem como desenvolver políticas que considerem as variadas identidades masculinas e femininas e não somente a masculinidade ou a feminilidade hegemônicas. 


\section{REFERÊNCIAS}

ACKER, S. Teoría feminista y estudio sobre género y educación. In:

Género y educación: Reflexiones sociológicas sobre mujeres, enseñanza y feminismo. Madrid, ed. Nancea, 1995 cap. 3, p. 63-95.

AFONSO, L. Gênero e processo de socialização em creches comunitárias. Cadernos de Pesquisa, São Paulo, n. 93, p. 12-21, maio 1995.

ALVES, Nuno Correia; FIGUEIRAS, Maria José. Queixas subjectivas de saúde, afectividade negativa e utilização de serviços de saúde: Diferenças de género. Análise Psicológica, 25 (3), p. 415-425; 2007.

ANDRADE-LOPES, A.. Formação e práticas de profissionais da saúde em interação com pacientes oncológicos. Tese de Doutorado (Doutorado em Educação Especial) Universidade Federal de São Carlos, p. 273, 2003.

ANDRADE-LOPES, A.; COMBINATO, D. S.; REALI, A. M. M. R. Desenvolvimento e aprendizagem profissional de agentes educacionais: um estudo que envolve a área da saúde. In: SILVA, A.; Abramowicz A.; Bittar, M. (Org.). Educação e pesquisa: diferentes percursos, diferentes contextos. São Carlos: RIMA, 2004, v. 1, p. 289-308.

AQUINO, E. M. L. Saúde do homem: uma nova etapa da medicalização da sexualidade? Ciência \& Saúde Coletiva, Rio de Janeiro, ano 10, n.1, p.19-22, 2005.

AZEVEDO, K. R.; ARRAIS, A. R. O mito da mãe exclusiva e seu impacto na depressão pós-parto. Psicologia: Reflexão e Crítica, ano 19, n.2, p. 269-276, 2006.

BARDIN, L. Análise de conteúdo. Lisboa: Edições 70, 1979.

BELOTTI, E. G. Educar para a submissão: o descondicionamento da mulher. Petrópolis: Vozes, 1975.

BORDO, S. R.. O corpo e a reprodução da feminilidade: uma apropriação feminista de Foucault. In: JAGGAR, A. M.; BORDO, S. R. Gênero, corpo, conhecimento. Rio de Janeiro: Rosa dos Tempos, 1997. p. 21 -41.

BOURDIEU, P. A dominação masculina. Rio de Janeiro: Bertrand Brasil, 2003. 
BRAZ, M. A construção da subjetividade masculina e seu impacto sobre a saúde do homem: reflexão bioética sobre justiça distributiva. Ciência \& Saúde Coletiva, Rio de Janeiro, ano 10, n.1, p.97-140, 2005.

BUTLER, J. Problemas de gênero: feminismo e subversão da identidade. 2 ed. Rio de Janeiro: Civilização Brasileira, 2008.

CAMPOS, L. F. L. Métodos e técnicas de pesquisa em Psicologia. Campinas: Editora Alínea, 2000.

CONNELL, R. W. Políticas da Masculinidade. Educação e Realidade, v. 20, n. 2, p. 185 206, 1995.

COSTA-JUNIOR, Florêncio Mariano da; ANDRADE-LOPES, Alessandra de. Apoio social e enfrentamento de profissionais da saúde em interação com mulheres com câncer da mama. Relatório de pesquisa de iniciação científica, 2007.

COSTA-JUNIOR, Florêncio Mariano da; MAIA, Ana Cláudia Bortolozzi. Concepções de homens hospitalizados sobre a relação entre gênero e saúde. Psicologia: Teoria e Pesquisa, v.25, n.1, pp. 55-63, 2009.

COURTENAY, W. H. Constructions of masculinity and their influence on men's wellbeing: a theory of gender and health. Social Science \& Medicine, v. 50, p. 1385-1401, 2000 .

COUTO, M. T.; SCHRAIBER, L. B.; D'OLIVEIRA, A. F. P. L.; KISS, L. B.; Concepções de gênero entre homens e mulheres de baixa renda e escolaridade acerca da violência contra a mulher. Ciênc. saúde coletiva, v.11, sup. p. 1323-1332, 2006.

COZBY, P. C. Métodos de pesquisa em ciências do comportamento. São Paulo: Atlas, 2003.

DARWIN C. Origem do homem e a seleção sexual. São Paulo, Hemus, 1974.

DOYAL, L. Sex, Gender, and health: the need for a new approach. British Medical Journal, v. 323, p.1061-1063, 2001. Disponível em: http://www.bmj.com. Acesso 22 Abr. 2007. 
FIGUEIREDO, W. Assistência à saúde dos homens: um desafio para os serviços de atenção primária. Ciência \& Saúde Coletiva, Rio de Janeiro, v. 10, n.1, p.105-109, 2005.

FOUCAULT, M. História da Sexualidade I: a vontade de saber. São Paulo: Graal, 2005.

FOUCAUlT, M. História da Sexualidade II: O uso dos prazeres. Rio de Janeiro: Graal,1984.

FOUCAUlT, M.. Microfísica do Poder. $2^{\underline{a}}$ ed. Rio de Janeiro: Graal, 1981.

GAWRYSZEWSKI, V. P.; KOIZUMI, M. S.; MELLO-JORGE, M. H. P. (2004). Causas externas no Brasil no ano de 2000: comparando a mortalidade e a morbidade. Cad. Saúde Pública, 20(4), 995-1003.

GIFFIN, K. M. A inserção dos homens nos estudos de gênero: contribuições de um sujeito histórico. Ciência e saúde coletiva, ano 10, n. 1, p. 47-57, 2005.

GIFFIN, K. M. Nosso corpo nos pertence: a dialética do biológico e do social. Cad. Saúde Pública, vol.7, n.2 pp. 190-200, 1991.

GOMES, R. Sexualidade masculina, gênero e saúde. Rio de Janeiro: Ed. FIOCRUZ, 2008.

GOMES, R.; NASCIMENTO E.F. A produção do conhecimento da saúde pública sobre a relação homem-saúde: uma revisão bibliográfica. Cad. de Saúde Pública, Rio de Janeiro, ano 22, n. 5, p. 901-911, 2006.

GOMES, R. Sexualidade masculina e saúde do homem: proposta para uma discussão. Ciência \& Saúde Coletiva, Rio de Janeiro, ano 8, n.3, p. 825-829, 2003.

GOMES, R.; NASCIMENTO, E. F.; ARAÚJO, F. C. Por que os homens buscam menos os serviços de saúde do que as mulheres? As explicações de homens com baixa escolaridade e de homens com ensino superior. Cad. de Saúde Pública, Rio de Janeiro, ano 23, n. 3, p. 556-574, 2007.

GRACIANO, M. Aquisição de papéis sexuais na infância. Cadernos de Pesquisa, São Paulo, n.25, p.29-44, junho, 1978. 
HIDALGO, Victoria; PALÁCIOS, Jesus. Desenvolvimento da personalidade entre os dois e sete anos. In COLL. C.; MARCHESI, A.; PALACIOS, J. (org) Desenvolvimento psicológico e educação. Trad. Deisy Vaz de Moraes. Porto Alegre: Artmed, 2004.

KARRAKER, K. H.; VOGEL D. A; LAKE, A. Parents' gender-stereotyped perceptions of Newborns: The Eye of the Beholder revisited. Sex Roles, Vol. 33, p. 687- 701, 1995.

KORIN, D. Nuevas perspectivas de gênero en salud. Adolescência Latinoamericana, ano 02, n. 2, p. 67-79. 2001.

KRIEGER, N. e FEE, E. Man-made medicine and women's health: the biopolitics of sex/gender and race/ethnicity. International Journal of Health Services, ano 24, n.2, p. 265-283, 1994.

LAQUEUR, T. W. Inventando o sexo: corpo e gênero dos gregos a Freud. Tradução Vera Whately, Rio de Janeiro: Relume Dumará, 2001.

LAMAS, M. Gênero: os conflitos e desafios do novo paradigma. Proposta. Rio de Janeiro, $n^{\circ} 84 / 85$, p. 12-25, 2000.

LAMAS, M. O Gênero é cultura? In: V Campus euroamericano de cooperação cultural, Almada 2007.

LORENZ, K. Os fundamentos da Etologia. São Paulo: Editora da Universidade de São Paulo, 1995.

LOURO, G. P. Gênero, sexualidade e educação: uma perspectiva pós-estruturalista. $5^{\text {a }}$ ed. Petrópolis: Vozes, 2003.

LOURO, G. P. Teoria Queer - uma política pós-identitária para a educação. Estudos Feministas, ano 9, n 2, p. 541-553, 2001.

MACINTYRE, S.; FORD, G. E HUNT, K. Do women "over-report" morbidity? Men's and women's responses to structured prompting on a standard question on long standing illness. Social Science \& Medicine, v. 48, p. 89-98, 1999.

MAGALHÃES, J. C.; RIBEIRO, P. R. C. As neurociências ensinando modos de ser homem e mulher em revistas de divulgação científica. Revista eletrônica de Enseñanza de lãs Ciências, ano 8, n 02, p. 692-710, 2009. 
MAIA, Ana Cláudia Bortolozzi; MAIA, Ari Fernando. Educação para as questões de Gênero e Diversidade Sexual. In: Mara Sueli Simão Moraes; Elisandra André Maranhe (Orgs.). Educação na Diversidade e Cidadania Vol 4. Bauru:Unesp; Brasília: MEC/SECAD, 2009.

MAIA, A C. B. Identidade e papéis sexuais: uma discussão sobre gênero na escola. In: MAIA, Ana Cláudia Bortolozzi; MAIA, Ari Fernando (Orgs.) Sexualidade e infância. Cadernos CECEMCA nº1. Bauru, Faculdade de Ciências: Cecemca; Brasília: MEC/SEF, 2005, p. 66-82.

MANZINI, E. J. Entrevista semi-estruturada: análise de objetivos e de roteiros. In: Anais do Seminário internacional sobre pesquisa e estudos qualitativos, 2, 2004, Bauru. A Pesquisa qualitativa em Debate. Bauru: USC, 2004. Cd-room.

MANZINI, E. J. A entrevista na pesquisa social. Didática, São Paulo, v 26/27, p. 149$158,1991$.

MARTIN, E. A mulher no corpo: uma análise cultural da reprodução. Rio de Janeiro: Ed. Garamond, 2006.

MARTINS, A. P.V. Visões do feminino: a medicina da mulher nos séculos XIX e XX. Rio de Janeiro Ed. Fiocruz, 2004.

MAUSS, M. Sociologia e Antropologia. São Paulo, Epu/Edusp, 1974.

MEAD, M. Sexo e temperamento. São Paulo: Perspectiva. 1979.

MENDONCA, R. T. CARVALHO, A. C. D.; VIEIRA, E. M.; ADORNO, R. C. .F. Medicalização de mulheres idosas e interação com consumo de calmantes. Saúde soc., São Paulo, v. 17, n. 2, jun. 2008. Disponível em $<$ http://www.scielo.br/scielo.php?script=sci_arttext\&pid=S0104-12902008000200010\& lng=pt\&nrm=iso $>$. Acesso em 05 ago. 2009.

MENEZES, R. A.; HEILBORN, M. L. A inflexão de gênero na construção de uma nova especialidade médica". Revista Estudos Feministas, dezembro, vol. 15, nº 3, p. 563- 580, 2007.

MEYER, Dagmar E. Gênero e educação: teoria e política. In: GOELLNER, Silvana; LOURO, G. L.; FELIPE, J. (org.). Corpo, gênero e sexualidade: um debate contemporâneo na educação. Petrópolis: Vozes, 2003a, p. 9- 27. 
MEYER, D. E. Escola, currículo e diferença: implicações para a docência. In: BARBOSA, R. L. L (org). Formação de educadores: desafios e perspectivas. São Paulo: Unesp, 2003b, p. $257-265$.

MINAYO M. C. S. Desafio do Conhecimento: pesquisa qualitativa em saúde. São Paulo: Hucitec; 2006.

MISKOLCI, R. A teoria Queer e a sociologia: o desafio de uma analítica da normatização. Sociologias, Porto Alegre, ano 11, n 21, p. 150-182, 2009.

MONTAGNER, M. A. Pierre Bourdieu, o corpo e a saúde: algumas possibilidades teóricas. Ciênc. saúde coletiva, Rio de Janeiro, v. 11, n. 2, p. 515-526, 2006.

MORENO, M. Como se ensina a ser menina: o sexismo na escola. Tradução de Ana Venite Fuzatto. São Paulo: Moderna; Campinas: UNICAMP, 1999.

MORO, C. C. A questão de gênero no ensino de ciências. Chapecó: ARGOS. 2001.

MOSSE, G. L. Masculinidade e decadência. In PORTER, R.; TEICH, M. (org). Conhecimento sexual, ciência sexual: a história das atitudes em relação à sexualidade. São Paulo: Fundação Editora Unesp, 1998.

NAVARRO, C. Z. Questões de gênero no contexto escolar. Monografia. 2005. 121. Trabalho de Conclusão de Curso (Curso de Pedagogia) - Faculdade de Ciências, Universidade Estadual Paulista, Bauru, 2005.

NOLASCO, S. A. O mito da masculinidade. 2 ed. Rio de Janeiro: Rocco, 1993.

NOVO DICIONÁRIO ELETRÔNICO AURÉLIO. Positivo Informática Ltda, 2004. versão 5.0, CD-ROM.

OLIVA, A. Desenvolvimento da personalidade durante a adolescência. In COLL. C.; MARCHESI, A.; PALACIOS, J. (org) Desenvolvimento psicológico e educação. Trad. Deisy Vaz de Moraes. Porto Alegre: Artmed, 2004a.

OLIVA, A. Desenvolvimento social durante a adolescência. In COLL. C.; MARCHESI, A.; PALACIOS, J. (org) Desenvolvimento psicológico e educação. Trad. Deisy Vaz de Moraes. Porto Alegre: Artmed, 2004b. 
OLIVEIRA, E. M. A ética do ponto de vista das mulheres que abortam. Revista Universidade e sociedade, ano 9, n 20 p. 171-180, 2000.

PARKER, R. G. Corpos, Prazeres e Paixões - a cultura sexual no Brasil contemporâneo. Tradução de Maria Therezinha Cavallari. São Paulo: Ed. Best Seller: 2000.

PEDRO, M. J. Traduzindo o debate: o uso da categoria gênero na pesquisa histórica. História, São Paulo, ano 24, n 01, p 77-98, 2005.

PINHEIRO, R. S. et al. Gênero, morbidade, acesso e utilização de serviços de saúde no Brasil. Ciência \& Saúde Coletiva, Rio de Janeiro, ano 7, n.4, p.105-109, 2002.

RABASQUINHO, C.; PEREIRA, H.. Gênero e saúde mental: uma abordagem epidemiológica. Análise Psicológica, 25, p. 439-454. 2007.

RAGO, M. Epistemologia feminista, gênero e história. In: PEDRO, J. M. e GROSSI, M. P. (orgs.) Masculino, Feminino, Plural. Florianópolis, Ed. Mulheres, 1998.

REIS, K. C. F. Infância, gênero e estereótipos sexuais: análise do relato de mães de crianças de 4 a 6 anos. Dissertação (Mestrado em Psicologia do Desenvolvimento e Aprendizagem), Faculdade de Ciências, Universidade Estadual Paulista, Bauru, 2008.

REY, L. Dicionário de termos técnicos de medicina e saúde. Rio de Janeiro, Guanabara Koogan S.A., 1999.

RIBAS, A. F.; MOURA, M. L.S. Responsividade e teoria do apego: uma discussão crítica do papel de estudos transculturais. Psicologia: Reflexão e Crítica, ano 17, n 3, p. 315322. 2004.

ROCHA, C. M. F. Desconstruções edificantes: Uma análise da ordenação do espaço como elemento do currículo. Dissertação de Mestrado. Porto Alegre: UFRGS/FACED/PPGEDU, 2000.

ROHDEN, F. Uma ciência da diferença: sexo e gênero na medicina da mulher. Rio de Janeiro: Ed. Fiocruz, 2001.

ROHDEN; F. Ginecologia, gênero e sexualidade na ciência do século XIX Horizontes Antropológicos, Porto Alegre, ano 8, n. 17, p. 101-125, 2002. 
ROHDEN, F. A construção da diferença sexual na medicina. Cad. Saúde Pública, Rio de Janeiro, ano 19, n.2, p. 201-212, 2003.

ROSA, M. V. F. P. C.; ARNOLDI, M. A. G. C. A entrevista na pesquisa qualitativa: mecanismo para validação dos resultados. Belo Horizonte: Autêntica, 2006.

SARTI, C. A. O feminismo brasileiro desde os anos 1970: revisitando uma trajetória. Estudos feministas, Florianópolis, ano 12, n 2, p. 35-50, 2004.

SARTI, C. A.. A dor, o indivíduo e a cultura. Saúde soc., vol.10, n.1, p. 3-13, 2001.

SCHIENBINGER, L. O feminismo mudou a ciência? Trad. Raul Fiker. Bauru: Edusc, 2001.

SCHRAIBER, L. B.; GOMES, R.; COUTO, M. T. Homens e saúde na pauta da Saúde Coletiva. Ciênc. saúde coletiva, v.10, n.1, p. 7-17, 2005.

SCOTT, J. Gênero: uma categoria útil de análise histórica. Educação \& Realidade, v. 20, n. 2 , p. $71-99,1995$.

SILVA, T. R. N.; GRACIANO, M.; GUARIDO, E. L. Estudo sobre estereótipos sexuais nas percepções dos pais em relação a comportamentos e atitudes de seus filhos. Cadernos de Pesquisa, São Paulo, n. 21, p. 15-40, 1976.

TELES, M. A. A. Breve histórico do feminismo no Brasil. 1 ed. São Paulo: Brasiliense. 1999.

UNBEHAUM, S. G. Gênero, Masculinidade e Prevenção. In: Seminário sobre cultura, saúde e doença, 01, Universidade Estadual de Londrina. Seminário sobre Cultura, Saúde e Doença, Londrina. 2003.

VAITSMAN, J. Flexíveis e plurais: identidade, casamento e família em circunstâncias pós-modernas. Rio de Janeiro: Rocco, 1994.

VIEIRA, E. M. A medicalização do corpo feminino. Rio de Janeiro: Ed. Fiocruz, 2002. VERBRUGGE, L. M. The Twain Meet: Empirical Explanations of Sex Differences in Health and Mortality. Journal of Health and Social Behavior, v. 30, p.282-304, 1989. 
VERbRUGGe, L. M. Sex Differentials in Health. Public Health Reports. 97 (5), p. 417 437, 1982.

WHITAKER, D. C. A. Menino - menina: sexo ou gênero? In: R. V. SERBINO; M. A. R. L. GRANDE, (Orgs.), A escola e seus alunos: o problema da diversidade cultural (p. 31-52). São Paulo: Unesp, 1995. 


\section{APÊNDICE 1}

\section{TERMO DE CONSENTIMENTO INFORMADO}

Declaro que fui convidado(a) a participar da pesquisa CONCEPÇÕES DE PROFISSIONAIS DA SAÚDE SOBRE QUESTÕES DE GÊNERO, sob orientação da Profa Dra. Ana Cláudia Bortolozzi Maia, lotada no Curso de Psicologia da Unesp-Bauru, que fui esclarecido(a) sobre os objetivos gerais da pesquisa, os procedimentos metodológicos envolvidos e as finalidades de divulgação dos dados de modo acadêmico e científico e que a pesquisa atende as exigências éticas da Resolução do Conselho Nacional de Saúde 196/96. (Diretrizes e Normas Regulamentadoras de Pesquisa envolvendo Seres Humanos/CONEP/Conselho de Ética em Pesquisa).

Declaro que fui informado(a) de que a minha participação na pesquisa é gratuita e não envolve nenhuma situação de risco à minha integridade física ou moral. Entendi que minha participação será a participar de uma entrevista gravada, que a minha identificação será mantida no anonimato e que posso desistir da participação em qualquer momento, além de manter contato para esclarecimentos com o pesquisador responsável.

Diante do exposto, declaro que recebi orientações e esclarecimentos do pesquisador responsável, Florêncio Mariano da Costa Júnior, quanto aos objetivos do estudo, aos procedimentos envolvidos na minha participação e ao anonimato garantido e concordo em participar, de forma voluntária, deste estudo, assinando termo de consentimento abaixo:

Eu, ,RG:

concordo em participar, de forma voluntária, deste estudo e autorizo a utilização das respostas que emiti neste questionário para fins de divulgação acadêmica e científica, desde que seja mantido o anonimato da minha identificação.

Local:

Data:

Assinatura:

Responsável: Psic. Florêncio Mariano da Costa Júnior

Pós-Graduação em Psicologia do Desenvolvimento e da Aprendizagem/

Faculdade de Ciências/Bauru. Telefone: (14) 31036087

E-mail: mcostajunior@gmail.com 


\title{
ANEXO 1 - Parecer de ética
}

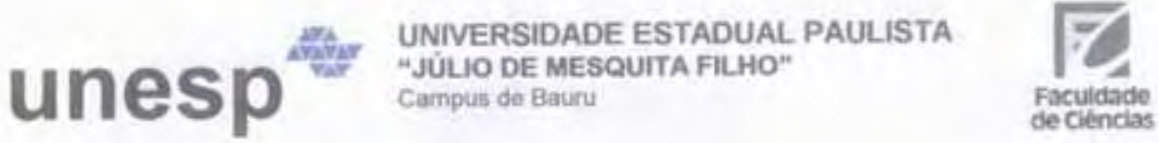

O Comitê de Ética em Pesquisa da Faculdade de Ciências da Universidade Estadual Paulista - UNESP, em sua $39^{*}$ Reuniâo Ordinária realizada no dia 19 de março de 2008, no Prédio do STI da Faculdade de Clências da UNESP. Campus de Bauru، às 09h00, após análise do parecer emitido pelo relator APROVA o projeto "Concepçōes de profissionais de saúde sobre questōes de gễnero", Processo $n^{\circ}$ 627/46/01/08, sob responsabilidade da Professora Doutora Ana Claudia Bortolozzi Maia.

Bauru (SP), 19 de março de 2008

PROF. DR. PAULO NORONHA LISBOA FILHO

Coordenador do Comitê de Etica em Pesquisa 